UNIVERSIDADE DE SÃO PAULO

INSTITUTO DE GEOCIÊNCIAS

\title{
ESTRUTURAS TRANSVERSAIS ÀS BACIAS DE TAUBATÉ E RESENDE: NATUREZA E POSSÍVEL CONTINUIDADE NA BACIA DE SANTOS, BRASIL
}

Thaís Trevisani Moura

Orientador: Prof. Dr. Claudio Riccomini

\section{DISSERTAÇÃO DE MESTRADO}

Programa de Pós-Graduação em Geoquímica e Geotectônica

SÃO PAULO 
Ficha catalográfica preparada pelo Serviço de Biblioteca e Documentação do Instituto de Geociências da Universidade de São Paulo

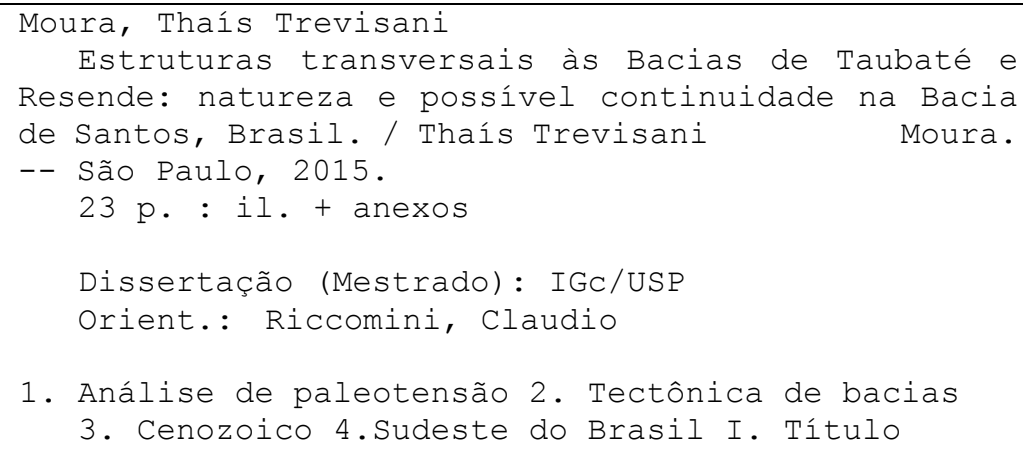


Dedico este trabalho aos meus pais, que sempre acreditaram em mim e me apoiaram incondicionalmente 


\section{AGRADECIMENTOS}

Aos meus pais, Jorge e Osana, por todo amor, apoio e incentivo, não só durante ao período que me dediquei ao Mestrado, mas SEMPRE.

Ao meu marido, Luis Felipe, pelo companheirismo e por, a despeito das adversidades, ter se juntado a mim em mais esta aventura.

Ao meu orientador, Prof. Dr. Claudio Riccomini pelo apoio, ensinamentos e contribuições de extremo valor para este trabalho.

Ao Instituto de Geociências pela formação acadêmica recebida e por todo apoio logístico e administrativo prestado. A seus professores e especialmente aos Profs. Drs. Liliane Janikian de Almeida Paes e André Oliveira Sawakuchi pelas orientações durante o acompanhamento do PRH-241.

Aos meus amigos, alguns conhecidos há pouco tempo e outros por uma eternidade, pelas discussões enriquecedoras, especialmente a Alexandra pela revisão do trabalho, e a Laura e Yohana pelo apoio e discussões durante essa jornada que compartilhamos.

À Penido Construtora e Pavimentadora, que nos permitiu a coleta de dados durante as obras do Aerovale, e ao Flávio Luis Gonçalves, que nos acompanhou durante a visita.

Ao Programa de Recursos Humanos Petrobras PRH-241, Agência Nacional do Petróleo, Gás Natural e Biocombustíveis (ANP), Financiadora de Estudos e Projetos (FINEP, Ref. 1452/13) e ao Conselho Nacional de Desenvolvimento Científico e Tecnológico (CNPq, Processo \# 307871/2010-0) pelo apoio financeiro. 
"It was during my enchanted days of travel that the idea came to me, which, through the years, has come into my thoughts again and again and always happily — the idea that geology is the music of the earth."

Hans Cloos,

(Conversation with the Earth) 


\section{RESUMO}

Moura, T.T. Estruturas transversais às bacias de Taubaté e Resende: natureza e possível continuidade na Bacia de Santos. 2015. 23 f. Dissertação (Mestrado) - Instituto de Geociências, Universidade de São Paulo, São Paulo.

As bacias de Taubaté e Resende são bacias continentais paleógenas do tipo rift, orientadas segundo a direção NE a ENE e fazem parte do segmento central do Rift Continental do Sudeste do Brasil. Ambas foram instaladas durante o Eoceno, resultantes de um campo de esforços distensivo de direção NW-SE. Este campo reativou zonas de cisalhamento de direção NE do embasamento pré-cambriano como falhas normais, importantes durante a instalação e evolução da bacia. Há também inúmeras estruturas transversais ao eixo da bacia, de direções N-S, NE-SW e NW-SE, as quais compreendem falhas e dobras que estiveram ativas durante diferentes intervalos de tempo, embora seus papeis na evolução da bacia ainda sejam pouco conhecidos. A fim de reconhecer estas estruturas em subsuperfície na Bacia de Taubaté, cinco perfis sísmicos longitudinais ao eixo da bacia foram interpretados, demonstrando o caráter distinto dessas estruturas como falhas normais e inversas, que interceptam diferentes unidades sísmicas, indicando uma deformação tectônica polifásica. A presença de altos estruturais transversais, distinguíveis em perfis sísmicos, ativos durante a abertura da bacia, pode estar relacionada com anticlinais formados na capa das falhas, durante uma evolução relacionada ao crescimento das falhas principais de borda em um regime distensivo de direção NW-SE. Ainda, foram descritas em afloramentos falhas sinsedimentares de componente normal, de direção NW-SE e transversais à Bacia de Resende, dispostas em um alto ângulo com relação à orientação ENE das falhas principais de borda. Estas estruturas foram interpretadas como falhas de alívio formadas no mesmo contexto distensivo. As relações estratigráficas e a análise de paleotensões das populações de falhas indicaram que as estruturas transversais estão relacionadas a quatro eventos deformacionais: compressão NE-SW, provavelmente durante o Mioceno; compressão NW-SE, durante o Pleistoceno Superior; distensão E-W a NW-SE durante o Holoceno; e por fim compressão E-W relacionada ao campo de esforços atual. A evolução da Bacia de Santos na porção adjacente offshore durante o Cenozoico pode estar diretamente relacionada à presença de estruturas transversais, mudanças de campo de estresse e a geração e eventos deformacionais nas bacias continentais do tipo rift.

Palavras chave: Tectônica de bacias sedimentares, análise de paleotensões, Cenozoico, Sudeste do Brasil. 


\begin{abstract}
Moura, T.T. Transverse structures in Taubaté and Santos basins: nature and possible continuity in Santos Basin, Brazil. 2015. 23 f. MSc Dissertation. Instituto de Geociências, Universidade de São Paulo, São Paulo.

The Taubaté and Resende are NE-to-ENE-oriented Paleogene continental rift basins of the central segment of the Continental Rift of Southeastern Brazil. Both basins were installed during the Eocene as a result of a NW-SE-oriented extensional stress field. This stress field reactivated NE-trending shear zones of the Precambrian basement as normal faults, which played a major role during the basin installation and evolution. There are also numerous N-S, NE-SW and NW-SE-oriented structures transverse to the NE-trending basin axis. These structures comprise faults and folds that were active at different time intervals, but their role in the basin evolution is poorly understood yet. In order to recognize these structures in the subsurface in Taubaté Basin, five longitudinal seismic profiles were interpreted showing their distinctive character as normal and reverse faults, which intersect different seismic units and indicate a polyphasic tectonic deformation. The presence of transverse structural highs, recognizable in the seismic profiles, which were active during the opening of the basin, can be related to anticlines formed in the hangingwall during an evolution related to the growing of the border master faults in a NW-SE-trending extensional regime. Moreover, syn-sedimentary NW-SE-oriented transverse normal faults oblique to the ENE-orientation of the border master faults were described in outcrops in the Resende Basin. These structures are interpreted as release faults and thus formed in the same extensional context. Stratigraphic relationships and paleostress analysis of fault populations indicate that transverse structures are related to four deformational events: a NE-SW-oriented compression probably during the Miocene, a NW-SEoriented compression in the Late Pleistocene to Holocene, an E-W-to-NW-SE-oriented extension in the Holocene and lastly, an E-W-oriented compression related to the present-day stress field. The evolution of the adjoining offshore Santos Basin during the Cenozoic has a narrow correlation with the formation and evolution of Taubaté and Resende basins. The migration of depocenters in the Santos Basin during the Cenozoic can be associated with the presence of NW-SE-oriented transverse structures, changes in the stress fields, and generation and deformation events in the continental rift basins
\end{abstract}

Keywords: Tectonics of sedimentary basins, paleostress analysis, Cenozoic, Southeastern Brazil 


\section{LISTA DE FIGURAS}

Figura 1 - Localização da área de estudo (adaptado de Marques, 1990 e

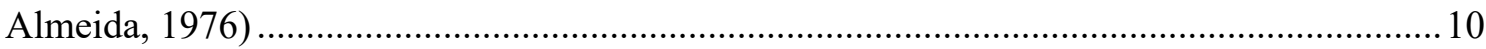

Figura 2 - Datação estratigráfica de falhas. As camadas superiores nas seções não são afetadas por falhas (Angelier 1994)

14

Figura 3 - Diedros retos e mecanismos de movimento em falhas. a) Visualização em perspectiva. b) Estereograma, hemisfério inferior. F: plano de falha; A: plano auxiliar; n: normal ao plano de falha; s: vetor de movimento; B: intersecção dos planos A e F; P: diedro compressivo; T: diedro distensivo (adaptado de Angelier 1994) 


\section{SUMÁRIO}

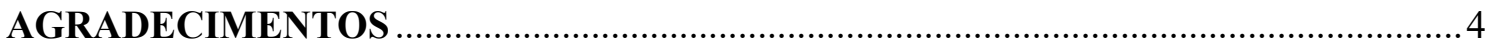

RESUMO

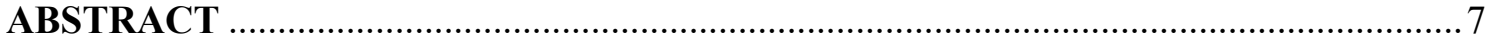

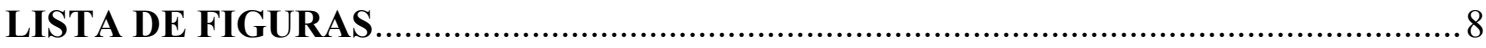

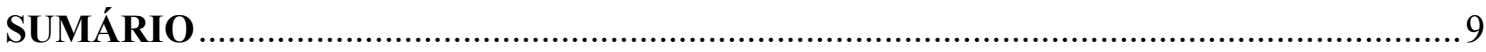

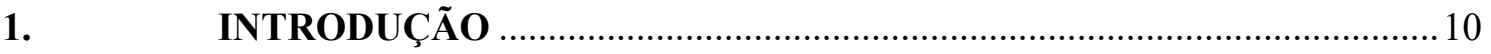

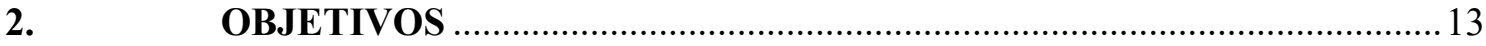

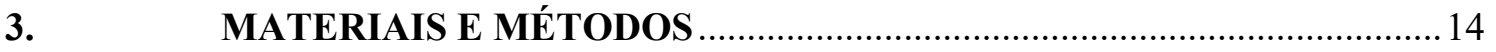

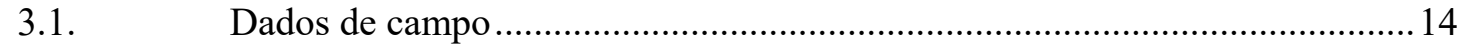

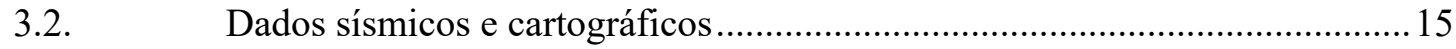

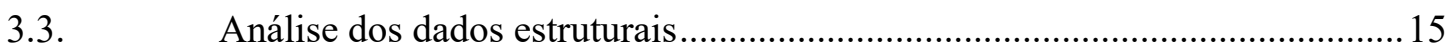

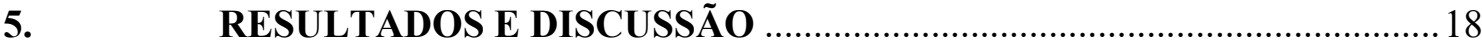

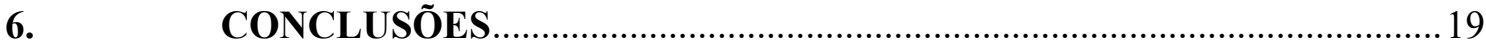

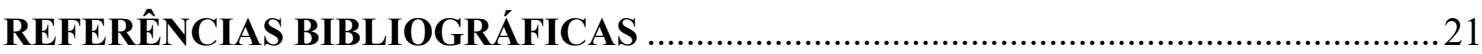

ANEXO 


\section{INTRODUÇÃO}

O Rift Continental do Sudeste do Brasil (RCSB) é uma depressão alongada, paralela à costa atual do sudeste do Brasil. Possui cerca de $900 \mathrm{~km}$ de comprimento, percorrendo três estados: Paraná, São Paulo e Rio de Janeiro (Riccomini, 1989). A evolução do RCSB se iniciou no Paleógeno sobre as rochas de médio a baixo grau metamórfico de idades paleo- a neoproterozoicas do Cinturão Ribeira (definido por Hasui et al. 1975), além de granitoides do Neoproterozoico (v.g. Alves et al. 2013).

No Cinturão Ribeira, a anisotropia das rochas e as zonas de fraqueza resultam do metamorfismo que ocorreu durante a Orogenia Brasiliana. Ao final do evento Brasiliano o setor central deste cinturão foi afetado por inúmeras falhas de componente transcorrente (Souza et al., 2009). De acordo com Campanha (2002), a evolução pós-Brasiliano está relacionada com os estágios de transição e reativação da Plataforma Brasileira, passando por um evento mesozoico em que expressivos movimentos verticais precederam um magmatismo básico e alcalino, até o desenvolvimento do Rift Continental do Sudeste do Brasil durante o Cenozoico.

De acordo com Riccomini et al. (2004) o RCSB pode ser dividido em três segmentos: ocidental, central e oriental. As bacias de Taubaté e Resende são depressões tectônicas localizadas entre a Serra do Mar e a Serra da Mantiqueira (Figura 1) e estão inseridas no segmento central do RCSB, assim como as bacias de São Paulo e Volta Redonda.

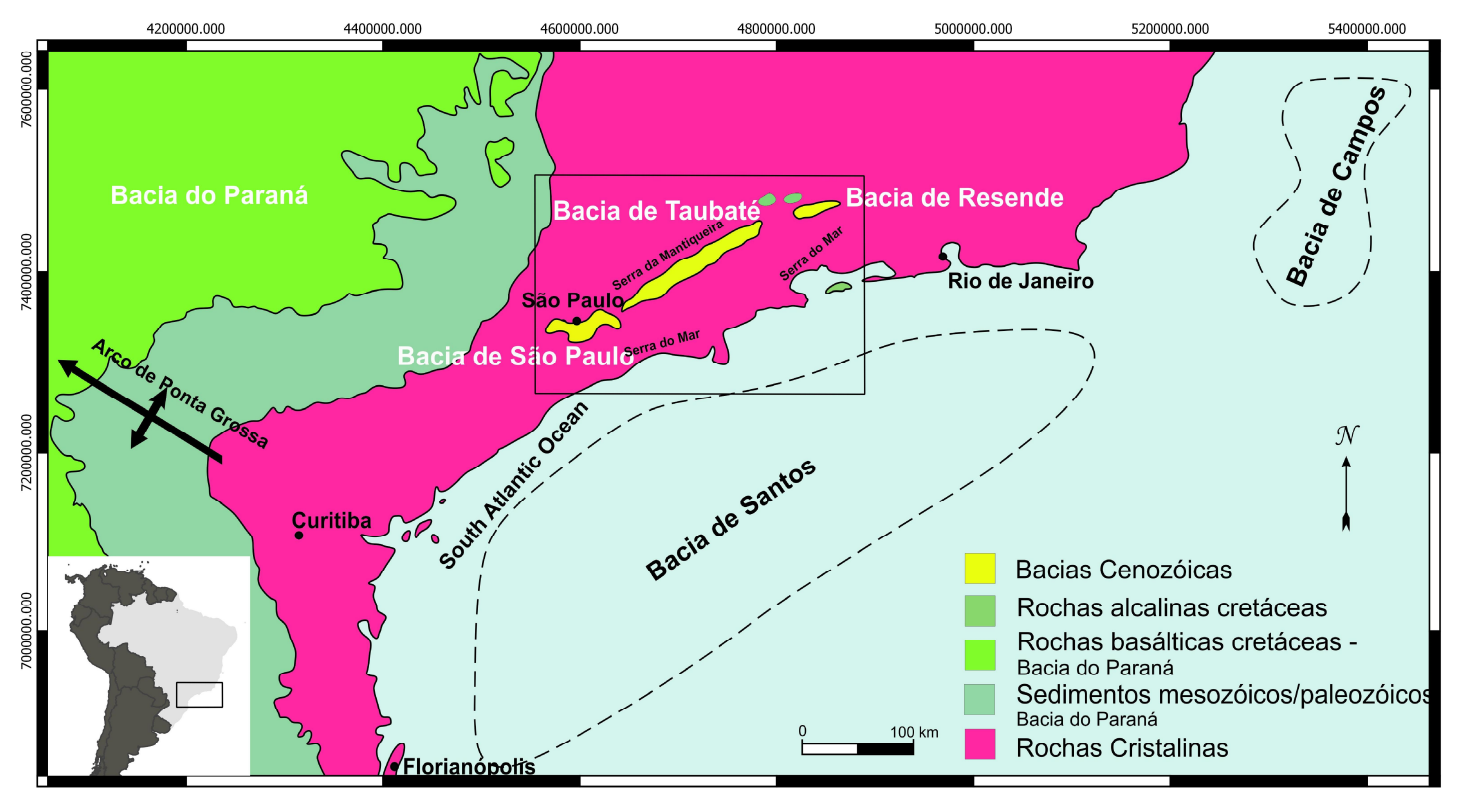

Figura 1 - Localização da área de estudo (adaptado de Marques, 1990 e Almeida, 1976) 
A principal fase de desenvolvimento do RCSB ocorreu durante o Eoceno-Oligoceno, com a deposição sintectônica do Grupo Taubaté, sedimentos depositados sintectonicamente (Riccomini et al., 2004).

A Bacia de Taubaté é a maior bacia desse sistema rift, possuindo $170 \mathrm{~km}$ de comprimento e $20 \mathrm{~km}$ de largura, com profundidade de até $850 \mathrm{~m}$, sendo reconhecidos seis depocentros (denominados por Marques, 1990, como Parateí, Jacareí, Eugênio de Melo, Quiririm, Roseira e Lorena, de SW para NE) que são separados por altos estruturais associados a falhas normais de direção NW-SE, informação essa corroborada por dados sísmicos (Marques, 1990) e dados gravimétricos (Fernandes \& Chang, 2002). Dois altos estruturais na Bacia de Taubaté foram identificados por Fernandes \& Chang (2002) que os denominaram de Alto de Caçapava e Alto de Pindamonhangaba. A Bacia de Resende, por sua vez, apresenta comprimento aproximado de $50 \mathrm{~km}$ e largura máxima de $8 \mathrm{~km}$.

Riccomini (1989) reconheceu dois sistemas de falhas transversais no RCSB, os sistemas NNW e NNE. O sistema NNE apresenta predominantemente falhas transcorrentes dextrais associadas a estruturas em flor negativas e positivas, assim como falhas normais e inversas. Este sistema controla altos estruturais que localmente expõem o embasamento pré-cambriano, além de baixos. Já o sistema NNW compreende principalmente falhas normais e transcorrentes sinistrais. Este sistema parece controlar o Alto Estrutural de Arujá, que expõe rochas do embasamento pré-cambriano e separa as bacias de São Paulo e Taubaté.

Além disso, dobramentos em escala regional foram reconhecidos mediante contorno estrutural efetuado a partir de dados de furos de sondagem em uma área delimitada pelas cidades de Taubaté, São José dos Campos e Pindamonhangaba (Riccomini, 1989). Takyia et al. (1990) investigou estas estruturas na Formação Tremembé usando krigagem geoestatística. Os resultados indicaram a presença de dobras cônicas com eixos de direção NNW que são correlacionáveis às dobras mesoscópicas identificadas em afloramentos da Formação Tremembé (Riccomini, 1989). Estas dobras são o resultado de uma compressão NE-SW ocorrida durante o Mioceno. Durante o Pleistoceno, as falhas de borda do rift foram reativadas, sob uma compressão NW-SE, que produziu novas dobras nos folhelhos da Formação Tremembé, criando assim um padrão de interferência do tipo domo e bacia (Riccomini 1989, Silva 2007).

Estruturas transversais de direção NW-SE também foram identificadas na Bacia de Santos por Souza et al. (2009). Tais estruturas atuaram durante a evolução da Bacia de Santos 
e segundo o autor eram persistentes continente adentro, interceptando as bacias de Taubaté e Resende.

A Bacia de Santos compreende uma área de $352.000 \mathrm{~km}^{2}$, localizada defronte aos estados de Santa Catarina, Paraná, São Paulo e Rio de Janeiro, sendo formada por processos de rifteamento durante a separação Afro-Americana no Mesozoico (Chang et al., 2008). O Cinturão Ribeira é também o embasamento principal da área mais rasa da Bacia de Santos, cujo preenchimento sedimentar é típico de um contexto de margens divergentes, formados por sequências continentais, transicionais e marinhas, com espessuras de até $13.000 \mathrm{~m}$ (Chang \& Kowsmann, 1984). 


\section{OBJETIVOS}

O objetivo deste trabalho é analisar as estruturas transversais às bacias de Taubaté e Resende, com enfoque em sua natureza, geometria, cinemática, relação com a sedimentação, idade, campos de esforços ativos durante a sua geração e deformação e correlação regional.

O controle exercido por falhas de alívio e falhas de transferência sobre a distribuição de campos de óleo e gás foi sugerido em estudos recentes (e.g. Destro et al. 2003). A identificação desses tipos de falhas na Bacia de Santos requer investigações sísmicas enquanto que estudos na porção onshore contígua (bacias do RCSB) é altamente facilitada pela possibilidade de observação direta.

Considerando este cenário, a evolução tectônica das bacias de Taubaté e Resende é relevante para compreender a evolução tectônica da Bacia de Santos durante o Cenozoico. A identificação de estruturas transversais na porção onshore certamente será importante no estudo da estruturação tectônica da Bacia de Santos, com implicações para a exploração de óleo e gás.

Portanto, é discutida a possibilidade de uma continuidade física dessas estruturas e/ou ação dos campos de esforços a elas relacionados na Bacia de Santos. 


\section{MATERIAIS E MÉTODOS}

\subsection{Dados de campo}

Considerando as controvérsias relacionadas à formação das estruturas transversais nas Bacias de Santos e Resende, o primeiro passo compreendeu o reconhecimento dessas estruturas na bibliografia e material cartográfico.

Assim, foram selecionados afloramentos que eram mais favoráveis à coleta de dados estruturais. Alguns dos afloramentos possuem um complexo cenário estrutural, sendo, portanto, importante identificar as relações de corte entre as falhas, assim como a relação destas com os depósitos sedimentares, a fim de se obter uma idade relativa dessas estruturas.

Com o objetivo de determinar a cronologia dos eventos de falhamentos foi utilizado o método descrito por Angelier (1994), que considera a idade das rochas afetadas ou não por falhas (Figura 2), a relação geométrica entre o deslocamento das falhas e a consistência mecânica. Também foi utilizada a relação de corte entre estrias de movimento identificadas em superfícies de falhas, pois algumas falhas se moveram ou foram reativadas sob mais de um evento deformacional. No entanto, esta relação de corte, com as estrias mais jovens interceptando as mais novas, nem sempre é clara, pois eventos mais antigos muitas vezes são mascarados ou mesmo apagados por eventos mais recentes, dificultando a reconstrução dos movimentos.
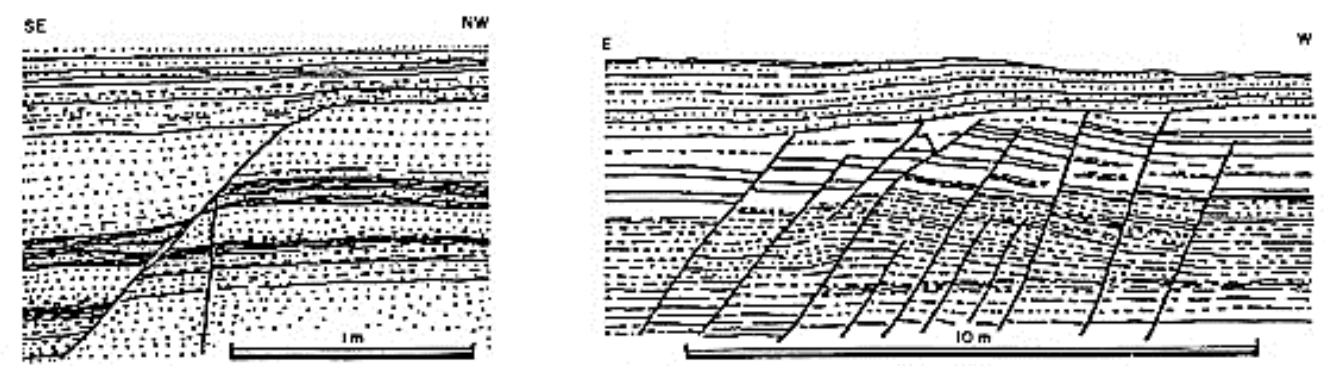

Figura 2 - Datação estratigráfica de falhas. As camadas superiores nas seções não são afetadas por falhas (Angelier 1994)

Além da coleta dos dados estruturais em campo, alguns afloramentos foram selecionados (especialmente pela sua importância e qualidade de dados) para apresentação como panoramas, utilizando-se o programa GIMP 2 aliado ao script Pandora. 


\subsection{Dados sísmicos e cartográficos}

A fim de compilar todo o material cartográfico, assim como analisar os modelos digitais de elevação, utilizou-se o programa Quantum Gis 2.6. Quatro imagens ASTER foram selecionadas a partir do ASTER GDEM (The ASTER Global Digital Elevation Model) que é um produto desenvolvido e disponibilizado ao público (no site gdem.ersdac.jspacesystems.or.jp) pelo METI - Ministry of Economy, Trade, and Industry - do Japão e pela NASA - United States National Aeronautics and Space Administration. As imagens são geradas a partir de dados coletados a partir de um instrumento óptico espacial chamado ASTER (Advanced Spaceborne Thermal Emission and Reflection Radiometer). O pós-intervalo é de $30 \mathrm{~m}$ e a precisão do modelo digital de terreno é entre 7 e $14 \mathrm{~m}$.

Os mapas geológicos assim como os estruturais foram obtidos através do GEOBANK CPRM (Companhia de Pesquisa de Recursos Minerais - disponível em: geobank.cprm.gov.br) enquanto os mapas hidrográficos foram obtidos a partir do IBGE (Instituto Brasileiro de Geografia e Estatística - disponível em www.ibge.gov.br).

Cogné et al. (2013) apresentou uma série de perfis sísmicos 2D, de alta resolução, disponibilizados pela Petrobras e adquiridos na década de 1980, para a região da Bacia de Taubaté. Assim, foram selecionados os perfis paralelos ao eixo longitudinal da bacia, a fim de identificar as estruturas transversais, em subsuperfície, assim como a sua relação com a sedimentação das unidades na bacia. Esta relação torna possível a datação relativa dos eventos de geração (falhas sinsedimentares) e deformação (falhas pós- sedimentares) na bacia.

Além disso, os mapas de isópacas da Bacia de Santos, obtidos a partir de Assine et al. 2008, foram analisados a fim de se comparar a migração dos depocentros na Bacia de Santos com os eventos deformacionais observados nas bacias de Taubaté e Resende.

\subsection{Análise dos dados estruturais}

Para determinação das paleotensões se escolheu utilizar o método dos diedros retos, proposto por Angelier e Mechler (1977). Trata-se de um método gráfico de determinação de paleotensões. Tal método não objetiva a determinação de um tensor médio de esforços, mas permite definir regiões de confiança onde se situam os principais eixos de esforços. Assim, para cada falha, dois diedros retos estão em compressão e dois em distensão, sendo eles limitados pelo plano da falha e pelo plano auxiliar. Assim, a orientação do eixo de esforço máximo $\sigma_{1}$ deve pertencer ao diedro compressivo, enquanto a orientação do eixo de esforço mínimo $\sigma_{3}$ 
pertence ao diedro distensivo. Consequentemente, onde dois ou mais movimentos de falhas ocorrerem sob o mesmo regime de esforços, o eixo principal deve pertencer ao mesmo diedro para todos os mecanismos de falhas, de modo que áreas residuais indicam um intervalo de possibilidades para os eixos principais de esforços (Angelier, 1994). A Figura 3 resume as principais características do método dos diedros retos e do mecanismo de falhas.
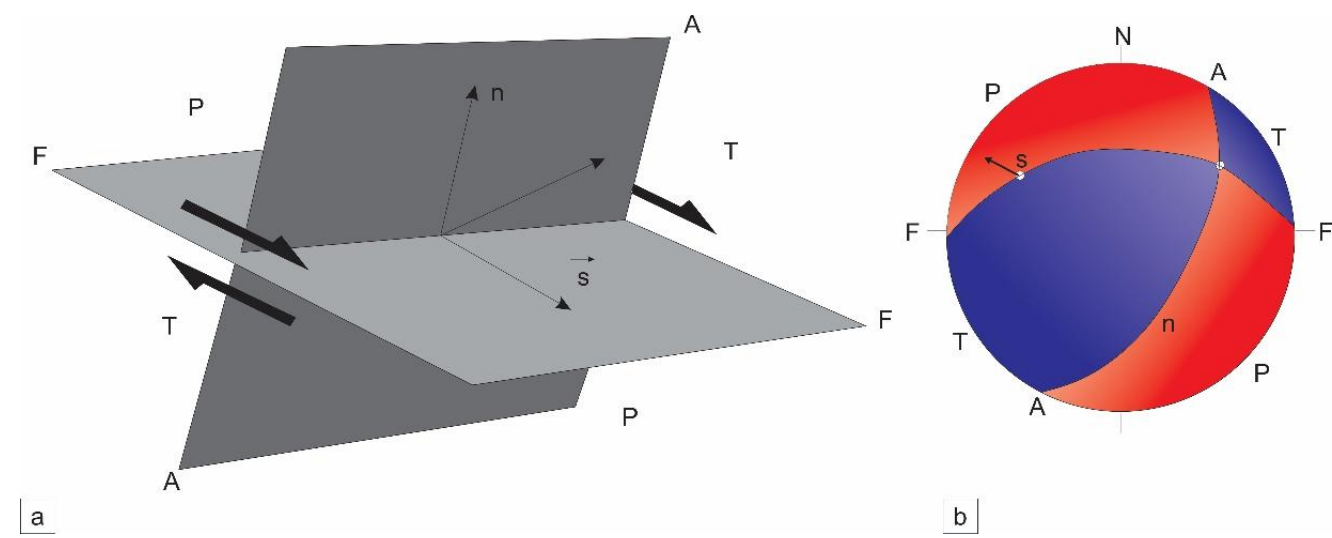

Figura 3 - Diedros retos e mecanismos de movimento em falhas. a) Visualização em perspectiva. b) Estereograma, hemisfério inferior. F: plano de falha; A: plano auxiliar; $n$ : normal ao plano de falha; $s$ : vetor de movimento; B: intersecção dos planos A e F; P: diedro compressivo; T: diedro distensivo (adaptado de Angelier 1994)

Este método foi aplicado com o uso do programa T-Tecto 3.0 (Žalohar \& Vrabec, 2007), que permite utilizar análise micropolar e clássica de sistemas de falhas homogêneos e heterogêneos a partir de diferentes métodos numéricos, incluindo o de Gauss para a determinação dos tensores, separando sistemas de falhas heterogêneos em subsistemas homogêneos. A análise considera que a direção do rejeito em um conjunto de falhas diferentemente orientadas pode ser explicada por um único tensor.

O método Gauss para separação de sistemas de falhas heterogêneos em subsistemas de falhas homogêneos, descrito em Žalohar \& Vrabec (2007), é baseado na filosofia tradicional de inversão de dados de rejeito em falhas (fault-slip data inversion), que envolve o conceito de tensor mais adequado (best-fit stress tensor). Primeiro, a "função de compatibilidade" é definida como uma função gaussiana, que depende da "medida de compatibilidade", levando em consideração: (1) a diferença angular entre a tensão cisalhante determinada e a direção atual de movimento no plano da falha e (2) a razão entre a tensão normal e cisalhante no plano da falha, desde que assumido que os resultados da inversão de tensão estejam em concordância com a Lei de Amonton. 
Adicionalmente, foi utilizada a visualização mediante o emprego do método multipleslip que compreende a soma dos campos compressivos e distensivos de todas as falhas, o que conduz a campos $\mathrm{P}$ e $\mathrm{T}$ comuns.

Os dados coletados em campo foram digitados em planilhas do tipo xls e foram adequados para a entrada no banco de dados do T-Tecto 3.0, empregando-se o programa Tectonics FP 1.6.2. Trata-se de uma planilha do tipo xls, na qual os dados de entrada são aqueles coletados em campo (atitudes do plano de falha, estrias e sentido do movimento).

Com o emprego do T-Tecto 3.0 também foi possível traçar os estereogramas estruturais utilizando-se a rede de Wulf (projeção de igual ângulo), hemisfério inferior. 


\section{RESULTADOS E DISCUSSÃO}

Os resultados obtidos neste trabalho bem como a discussão fazem parte do manuscrito intitulado "Transverse structures in Taubaté and Santos basins: nature and possible continuity in Santos Basin, Brazil", que consta do Anexo. Este manuscrito foi preparado para submissão para publicação em periódico internacional. 


\section{CONCLUSÕES}

O enfoque principal deste trabalho foi o estudo das estruturas transversais às bacias de Taubaté e Resende, principalmente sua natureza, geometria, cinemática, relações com a sedimentação, idade, o campo de esforços ativo durante sua geração e deformação e correlações regionais. Além disso, a possibilidade de uma continuidade física dessas estruturas e/ou a ação de campos de esforços relacionados a elas na Bacia de Santos foram também discutidos. As principais conclusões deste trabalho são:

a) falhas transversas em perfis sísmicos apresentam altos mergulhos e possuem caráter normal, inverso e transcorrente; todas as unidades sísmicas são interceptadas por falhas, incluindo pacotes sedimentares mais jovens, porém todas as falhas foram identificadas como pré- e póssedimentares;

b) altos estruturais foram identificados em perfis sísmicos e alguns deles estiveram ativos durante a instalação da Bacia de Taubaté;

c) a existência de um alto estrutural ativo e a presença de uma unidade sísmica exclusiva em uma sub-bacia estaria relacionada ao crescimento de uma falha de borda, em um regime distensivo;

d) o método de inversão e a análise de paleotensões permitiu identificar estruturas transversais relacionadas a cinco eventos tectônicos previamente reconhecidos no segmento central do RCSB;

e) estruturas transversais relacionadas ao evento inicial de distensão NW-SE (Eoceno Oligoceno) são representadas por falhas normais sinsedimentares, relacionadas às falhas principais e, aparentemente, não interceptam ou conectam falhas normais diferentes, indicando um campo distensivo de direção NE-SW, o que permite classifica-las como falhas de alívio; f) falhas transversais associadas ao evento de compressão de direção NE-SW e distensão NWSE (Mioceno) são em parte sinsedimentares em relação à Formação Itaquaquecetuba; a espessura das camadas dobradas da Formação Tremembé, que é praticamente uniforme, e um padrão de dobramento en echelon indicam que essas dobras estão relacionadas com uma compressão de direção NE-SW, em regime transcorrente;

g) falhas transversais relacionadas ao evento de compressão NW-SE e distensão NE-SW (Pleistoceno Superior - Holoceno) são principalmente normais, com uma direção geral NWSE, afetando linhas de seixos e colúvios; algumas dessas falhas possuem mergulho sub-vertical e a superposição de estrias, verificada em alguns afloramentos, indica que tais falhas podem representar reativações de antigas falhas transversais de componente transcorrente; 
h) o evento de distensão E-W a NW-SE (Holoceno) gerou falhas transversais com uma direção geral N-S a NNE-WSW que interceptam a Formação Pindamonhangaba bem como linhas de seixos e colúvios arenosos sobrepostos;

i) poucas falhas transversais foram relacionadas à compressão de direção E-W (atual campo de esforços), na área de estudo; a direção variável e a natureza das falhas indicam que foram provavelmente formadas em eventos deformacionais pretéritos e reativadas, pois mostram uma alta dispersão na posição das estrias relacionadas a este evento, sendo as falhas reativadas provavelmente em um plano não ideal;

j) apenas as estruturas NW-SE exerceram influência sobre a Bacia de Santos durante sua evolução cenozoica; cinco lineamentos com esta direção foram reconhecidos nos mapas de isópacas, com possível continuidade na área offshore, controlando os depocentros na Bacia de Santos: os lineamentos A (continuidade do Alto Estrutural de Arujá) e B (prolongação do Alto Estrutural de Queluz), durante o Paleoceno-Oligoceno; os lineamentos A, C e D durante o Mioceno; e os lineamentos A e E durante o Pleistoceno Superior ao Recente;

h) estas estruturas estiveram ativas predominantemente como falhas de transferência, dividindo a Bacia de Santos em compartimentos; em particular, o lineamento A, que corresponde à extensão offshore de Alto Estrutural de Arujá, parece ter tido uma persistente e polifásica atividade durante o Cenozóico;

i) os maiores campos de óleo na Bacia de Santos estão localizados na região contígua às bacias de Taubaté e Resende, grosseiramente entre os lineamentos A e B, de direção NW-SE, o que poderia sugerir uma influência combinada dessas estruturas com outras falhas e dobras de direção NW-SE nas rotas de migração e formação de armadilhas estruturais na Bacia de Santos. 


\section{REFERÊNCIAS BIBLIOGRÁFICAS}

Almeida F.F.M., 1976. The system of continental rifts bordering the Santos Basin, Brazil. Anais da Academia Brasileira de Ciências 48 (suplemento), 15-26.

Alves A., Janasi V.A., Campos Neto M.C., Heaman L., Simonetti A., 2013. U-Pb geochronology of the granite magmatism in the Embu Terrane: Implications for the evolution of the Central Ribeira Belt, SE Brazil. Precambrian Research 230, 1-12.

Angelier J., Mechler P., 1977. Sur une méthode graphique de recherche des contraintes principalel égalament utilisable em tectonique et em séismologie: la méthode des dièdres droits. Bulletin Société Géologique de France 19, 1309-1318

Angelier J., 1994. Fault slip analysis and paleostress reconstruction. In: Hancock P.L. (eds). Continental Deformation. Oxford, Pergamon, p. 53-120.

Assine M.L., Corrêa F.S., Chang H.K., 2008. Migração de depocentros na Bacia de Santos: importância na exploração de hidrocarbonetos. Revista Brasileira de Geociências 38(Suplemento), 111-127.

Campanha G. A.C., 2002. O papel do sistema de zonas de cisalhamentos transcorrentes na configuração da porção meridional da Faixa Ribeira. Tese de livre-docência. Instituto de Geociências, Universidade de São Paulo, 105 p.

Chang H.K., Kowsmann R.O., 1984. Subsidência térmica e espessura crustal na Bacia de Santos. In: $33^{\circ}$ Congresso Brasileiro de Geologia, Anais, v.2, p. 1602-1614.

Chang H.K., Assine M.L., Corrêa F.S., Tinen J.S., Vidal A.C., Koike L., 2008. Sistemas petrolíferos e modelos de acumulação de hidrocarbonetos na Bacia de Santos. Revista Brasileira de Geociências 38 (2 - suplemento), 29-46.

Cogné N., Cobbold P.R., Riccomini C., Gallagher K., 2013. Tectonic setting of the Taubaté Basin (Southeastern Brazil): Insights from regional seismic profiles and outcrop data. Journal of South American Earth Sciences 42,194-204. 
Destro N., Szatmari P., Alkmin F.F., Magnavita L.P., 2003. Release faults, associated structures, and their control on petroleum trends in the Recôncavo rift, northeast Brazil. $A A P G$ Bulletim 87, 1123-1144.

Fernandes F.L \& Chang H.K., 2002. Modelagem gravimétrica da Bacia de Taubaté. Revista Brasileira de Geofísica 19, 131-144.

Hasui Y., Carneiro C.D.R., Coimbra A.M., 1975. The Ribeira folded belt. Revista Brasileira de Geociências 5, 257-266.

Marques A., 1990. Evolução tectono-sedimentar e perspectivas exploratórias da Bacia de Taubaté, São Paulo, Brasil. Boletim de Geociências da Petrobras 4, 221-240.

Riccomini C., 1989. O Rift Continental do Sudeste do Brasil. PhD thesis, Instituto de Geociências, Universidade de São Paulo, 256 p.

Riccomini C., Sant'Anna L.G., Ferrari, A.L., 2004. Evolução geológica do rift continental do Sudeste do Brasil. In: Mantesso-Neto V.; Bartorelli A.; Carneiro C.D.R.; Brito Neves B.B. (eds.) Geologia do continente Sul-Americano: evolução da obra de Fernando Flávio Marques de Almeida. Beca, São Paulo, p. 383-405.

Silva T.B., 2007. Estocagem subterrânea de gás na Bacia de Taubaté. Final course assignment. Instituto de Geociências, Universidade de São Paulo, 41 p..

Souza I.A., Ebert H.D., Castro J.C., Soares Júnior A.V., Silva G.H.T., Benvenutti C.F., 2009. Caracterização das falhas de transferência na porção norte da Bacia de Santos a partir da integração de dados geológicos e geofísicos. Boletim de Geociências da Petrobras 17, 109132.

Takiya H., Riccomini C., Landim P.M.B., 1990. Estudo tectônico da porção central da Bacia de Taubaté (SP) por geoestatística. Geociências 9, 185-196.

Žalohar J., Vrabec M., 2007. Paleostress analysis of heterogeneous fault-slip data: The Gauss method. Journal of Structural Geology 29, 1798-1810. 
ANEXO 
TRANSVERSE STRUCTURES IN TAUBATÉ AND RESENDE BASINS: NATURE AND POSSIBLE CONTINUITY IN SANTOS BASIN, BRAZIL

Thaís Trevisani Moura ${ }^{1}$, Claudio Riccomini ${ }^{1,2}$

${ }^{1}$ Programa de Pós-Graduação em Geoquímica e Geotectônica, Instituto de Geociências, Universidade de São Paulo, Rua do Lago 562, CEP 05508-080, São Paulo, SP, Brazil; e-mail: thaistrevisani@gmail.com

${ }^{2}$ Instituto de Energia e Ambiente, Universidade de São Paulo, Avenida Professor Luciano Gualberto 1289, CEP 05508-010, São Paulo, SP, Brazil, and Research Fellow of Conselho Nacional de Desenvolvimento Científico e Tecnológico, CNPq, Brazil; e-mail: riccomin@usp.br

\section{ABSTRACT}

The Taubaté and Resende are NE-to-ENE-oriented Paleogene continental rift basins of the central segment of the Continental Rift of Southeastern Brazil. The Taubaté Basin, with about $170 \mathrm{~km}$ long and up to $20 \mathrm{~km}$ wide, and the Resende Basin, with $50 \mathrm{~km}$ long and up to $8 \mathrm{~km}$ wide, were installed during the Eocene as a result of a NW-SE-oriented extensional stress field. This stress field reactivated NE-trending shear zones of the Precambrian basement as normal faults that played a major role during the basin installation and evolution. There are also numerous N-S, NE-SW and NW-SE-oriented structures transverse to the NE-trending basin axis. These structures comprise faults and folds that were active at different time intervals, but their role in the basin evolution is poorly understood yet. In order to recognize these structures in the subsurface in Taubaté Basin, five longitudinal seismic profiles were interpreted showing their distinctive character as normal and reverse faults, which intersect different seismic units and indicate a multiphase tectonic deformation. The presence of transverse structural highs, recognizable in the seismic profiles, which were active during the 
opening of the basin, can be related to anticlines formed in the hangingwall during an evolution related to the growing of the border master faults in a NW-SE-trending extensional regime. Moreover, syn-sedimentary NW-SE-oriented transverse normal faults oblique to the ENE-orientation of the border master faults were described in outcrops in the Resende Basin. These structures are interpreted as release faults (in the sense of Destro, 1995 and Destro et $a l ., 2003)$ and thus formed in the same extensional context. Stratigraphic relationships and paleostress analysis of fault populations indicate that transverse structures are related to four deformational events: a NE-SW-oriented compression probably during the Miocene, a NWSE-oriented compression in the Late Pleistocene to Holocene, an E-W-to-NW-SE-oriented extension in the Holocene and lastly, an E-W-oriented compression related to the present-day stress field. The evolution of the adjoining offshore Santos Basin during the Cenozoic has a narrow correlation with the formation and evolution of Taubaté and Resende basins. The migration of depocenters in the Santos Basin during the Cenozoic can be associated with the presence of NW-SE-oriented transverse structures, changes in the stress fields, and generation and deformation events in the continental rift basins. 


\section{INTRODUCTION}

The Continental Rift of Southeastern Brazil (CRSB, Riccomini, 1989) is an elongate narrow geomorphologic depression of Paleogene age, over $900 \mathrm{~km}$ long, that is roughly parallel to the current coastline. It developed over medium to low grade metamorphic rocks within the domain of the Ribeira Folded Belt (Hasui et al., 1975), of Paleo- to Neoproterozoic age, and intrusive granitoid rocks of Neoproterozoic age (v.g. Alves et al., 2013).

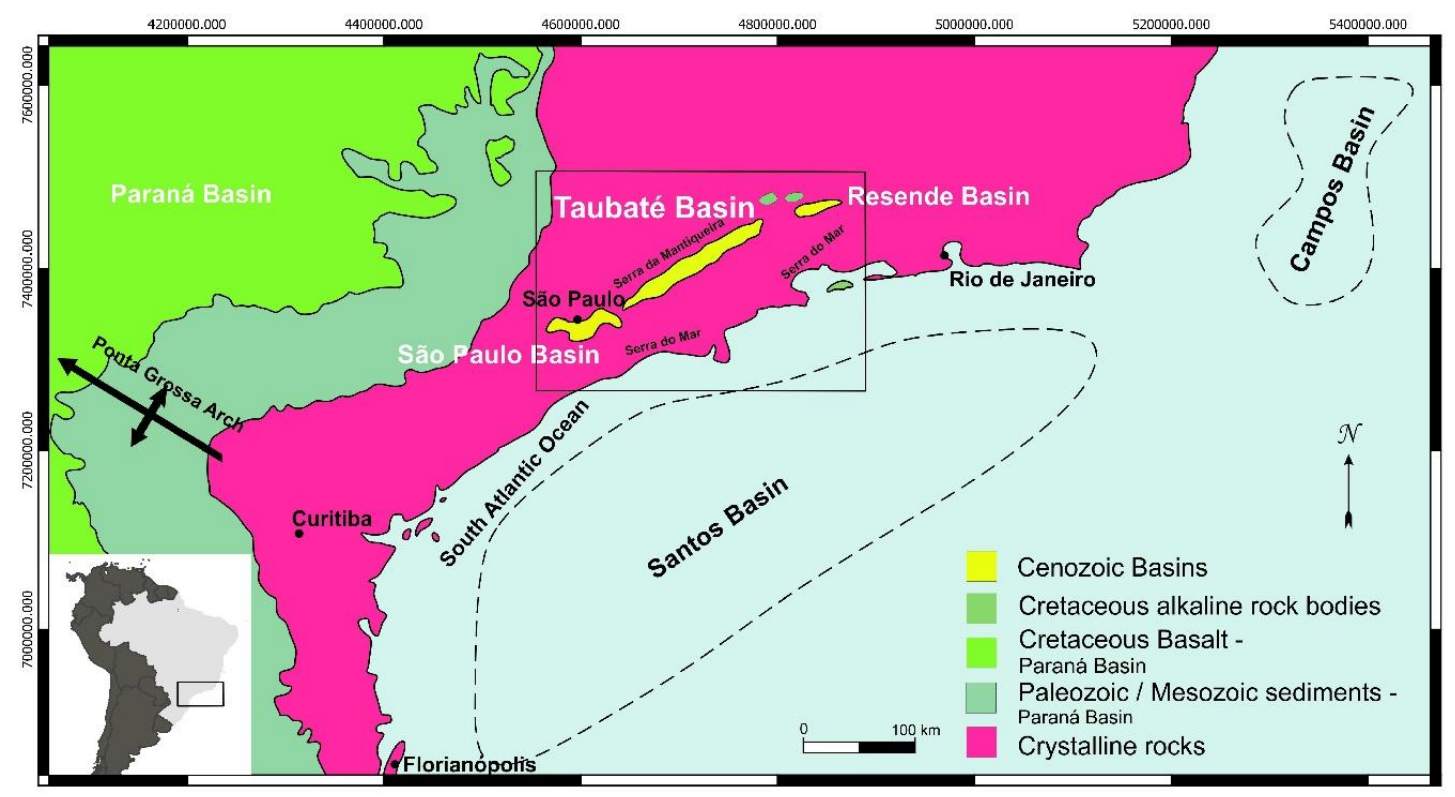

Figure 1 - Research area (adapted from Marques, 1990, and Almeida, 1976).

Major rock anisotropy and weak zones of the Ribeira Belt are the result of metamorphism, which occurred during the Brasiliano Orogeny. At the end of the Brasiliano event, the central sector of this belt was affected by multiple strike-slip faults (Souza et al., 2009). According to Campanha (2002), post-Brasiliano evolution is related to the transition and reactivation stages of the Brazilian Plataform, passing through a Mesozoic event with expressive vertical movements followed by basic and alkaline magmatism (v.g. Riccomini, 2005), up to the development of the Continental Rift of Southeastern Brazil during the Cenozoic. 
The Continental Rift of Southeastern Brazil may be subdivided in three segments: the Western, the Central (hosting São Paulo, Taubaté, Resende and Volta Redonda basins) and the Eastern segments (Riccomini et al., 2004). The Taubaté and Resende basins (Figure 1) are tectonic depressions located between the Serra do Mar and Serra da Mantiqueira, in the central segment of the Continental Rift of Southeastern Brazil.

The Taubate Basin is the largest basin in the rift system, and is about $170 \mathrm{~km}$ long and $20 \mathrm{~km}$ wide. Seismic data (Marques, 1990) corroborated by gravimetric data (Fernandes and Chang, 2002) indicates that it is composed of six depocenters separated by structural highs associated to NW-SE-oriented normal faults. The basement depth reach up to $850 \mathrm{~m}$. The Resende Basin also belongs to the central segment of the CRSB and it is located northeast of Taubaté Basin. It is elongated in the ENE-WSW-direction (N75E, Ramos et al., 2006), with $50 \mathrm{~km}$ long and up to $8 \mathrm{~km}$ wide, and the basin holds the same geological evolution as the Taubaté Basin.

The main phase of development of the Continental Rift of Southeastern Brazil occurred during the Eocene-Oligocene, and the syn-tectonic sedimentary filling corresponds to the Taubaté Group (Riccomini et al., 2004).

According to Marques (1990), the structural framework of the Taubaté Basin is defined by two major types of structures: right-lateral strike-slip faults, intersecting all sedimentary section, longitudinally to the basin, and normal transverse faults, controlling asymmetric horsts and grabens that delineate the six sub-basins (called from SW to NE: Parateí, Jacareí, Eugênio de Melo, Quiririm, Roseira and Lorena).

Fernandes and Chang (2002) identified two structural highs that were considered transfer zones, in the sense of Gibbs $(1984,1990)$. These highs subdivide the basin into three compartments, as hemigrabens, designated São José dos Campos, Taubaté and Aparecida, being the two structural highs denominated Caçapava High and Pindamonhangaba High. 
Riccomini (1989) recognized two systems of transverse faults in the CRSB, the NNEand the NNW-trending systems. The NNE-trending system presents an array of dominantly right-lateral strike-slip faults with associated negative and positive flower structures, as well as normal and reverse faults. This system also controls structural highs, locally with exposition of Precambrian basement rocks, and lows. The NNW-trending system comprises dominantly normal and left-lateral strike-slip faults that prevail over reverse and right-lateral strike-slip. This fault system seems to control the Arujá structural high, which exposes Precambrian basement rocks and separates the São Paulo and Taubaté basins (Riccomini, 1989).

Folding of regional scale was recognized from borehole data in the area bounded by the cities of Taubaté, São José dos Campos and Pindamonhangaba (Riccomini, 1989). Takiya et al. (1990) investigated these structures in Tremembé Formation using geostatistical kriging. The results indicated the presence of NNW-trending conical folds that are correlatable to mesoscopic folds recognized in outcrops of Tremembé Formation (Riccomini, 1989). These folds resulted from a NE-SW-compression occurred during the Miocene. During the Pleistocene, border faults from rift phase were reactivated, and the sedimentary rocks of Tremembé Formation were folded as a result of a NW-SE-oriented compression, creating a dome and basin pattern of interference (Riccomini, 1989, Silva, 2007).

Therefore, there are transverse faults in the Taubaté and Resende basins unrelated to transfer zones, which nature and relationship with sedimentation are slight known. Furthermore, Souza et al. (2009) indicate that NW-SE-trending structures had acted during the evolution of the Santos Basin and these structures are persistent inward the continent, intercepting the Taubaté Basin.

The Santos Basin has an area of $352.000 \mathrm{~km}^{2}$, facing the Rio de Janeiro, São Paulo, Paraná and Santa Catarina states, Brazil. The basin was formed by rifting processes during 
Mesozoic Afro-American separation (Chang et al., 2008). The Ribeira Belt is also the main basement in the shallow area of the Santos Basin, which sedimentary filling is typical of a divergent boundary, formed by continental, transitional and marine sequences, with up to $13.000 \mathrm{~m}$ thick (Chang and Kowsmann, 1984). As a result of recent oil and gas discoveries, the Santos Basin emerges as an auspicious exploratory frontier in Brazil. Nonetheless, its substantial area allied to scarcity of data and information about its geology grants it a limited known basin status (Chang et al., 2008).

The control played by release and transfer faults on the distribution of oil and gas fields has been suggested in recent studies (v.g. Destro et al., 2003). Identification of these types of faults in the Santos Basin requires seismic surveys, while their study in the adjoining onshore portion is highly facilitated by the possibility of direct observation. In this scenario, the tectonic evolution of the Taubaté and Resende basins is relevant to understanding the Cenozoic tectonic evolution of the Santos Basin. The identification of transverse structures in onshore portion certainly will be valuable in the study of the tectonic framework of the Santos Basin, with clear implications for oil and gas exploration.

Thus, this paper aims to analyze the transverse structures in the Taubaté and Resende basins with focus on their nature, geometry, kinematics, relationship with sedimentation, age, the stress field active during their generation and deformation, and regional correlations. We discuss the possible physical continuity of these structures and / or the action of stress fields related to them into the Santos Basin and the implications for the tectonic framework and evolution of this basin. 


\section{REGIONAL GEOLOGICAL SETTING}

The opening of South Atlantic initiated in the Early Cretaceous (v.g. Moulin et al., 2010), and is well documented by the huge basaltic volcanism and associated dikes and sills (Serra Geral Formation and correlated rocks).

It is assumed that both the Santos Basin and Serra do Mar escarpments started to develop at the end of this magmatic phase, although the controls on the current physiography of the coastal region of southeastern Brazil are still a matter of debate. Some authors proposed that the escarpments of the Serra do Mar result of secondary flexural bulge during the rift phase that would have persisted to the present day (Sacek et al., 2012). Fission-track data, however, indicates a rejuvenation of the topography by uplift during the Cenozoic (Hiruma et al., 2010; Cogné et al., 2011. 2012). Moreover, according to Franco-Magalhães et al. (2014), zircon fission-track data indicates a regional uplift during Early Cretaceous followed by strong erosion, and may reflect thermally driven tectonic activity. Yet, during the Late Cretaceous there was an uplift marked by intense alkaline magmatism without evidence of tectonism. At that time, the resulting highlands of Serra do Mar and Serra da Mantiqueira mountain ranges were the main source area for Late Cretaceous sediments of the passive margin basins (Santos and Campos basins) and the cratonic basin (Bauru Basin).

The structures of the Brasiliano Cycle had a strong influence on the disposition of the major features of the Continental Rift of Southeastern Brazil. The ENE-trend of the coastal region of southeastern Brazil is controlled by the Cambrian to Ordovician array of shear zones (Almeida, 1976). These shear zones were reactivated at the beginning of the Paleogene with a predominantly normal character, leading to syn-tectonic continental sedimentation of Taubaté Group (Riccomini et al., 1983, 1987, 1989; Melo et al., 1985), but the mechanisms that led to this reactivation are still poorly understood. Several models were proposed, as gravitational 
sliding (Almeida, 1976; Fernandes, 1993; Zalán and Oliveira, 2005), isostatic compensation (Asmus and Ferrari, 1978) and thermomechanical tilting (Riccomini, 1989).

The origin of the CRSB was previously related to a transtensional regime, a model based on the interpretation of left-lateral movements along border faults, as in Zalán (1986), Sadowski and Dias Neto (1981), Padilha et al. (1991) as well in recent works as Cobbold et al. (2001) and Cogné and et al. (2013). According to Cobbold et al. (2001) the Serra do Mar was exhumed once more in the Maastrichtian-Eocene (70-50 Ma). Between the Paleocene and Oligocene (70-30 Ma), continental sediments were deposited in pull-apart basins in a rightlateral transtensional regime, based on faults in Taubaté Basin that had northeast strikes, while striations had northerly pitches of $10^{\circ}-40^{\circ}$, indicating components of right-lateral slip, especially in syn-sedimentary faults.

Ferrari (2001) highlighted some important differences between extensional basins and basins along strike-slip faults. According to Christie-Blick \& Biddle (1985), basins along strike slip faults are distinct for some aspect of stratigraphic records that include: a tendency for longitudinal and lateral basin asymmetry, owing to the migration of the depocenters through time; evidence for episodic rapid subsidence, recorded by thick stratigraphic sections; and the occurrence of abrupt lateral facies changes and local unconformities. These characteristics were not found in the basins of the central segment of the CRSB. Thus the model of an initial NNW-SSE-oriented extension is accepted among several authors (Riccomini, 1989; Fernandes, 1993; Salvador, 1994; Ferrari, 2001; Riccomini et al., 2004; Zalán and Oliveira, 2005). This initial extensional phase is well documented by the normal character of the active master faults in the central segment of CRSB, as well as by data from striations and the continuity observed on proximal alluvial fan deposits and source areas (Riccomini et al., 2004). 
The syn-tectonic deposition in the Central segment of the Continental Rift of Southeastern Brazil, including the Taubaté and Resend basins, is encompassed in the Taubaté Group (Riccomini et al., 2004). The syn-rift deposition is represented by the Eocene to Oligocene Resende Formation, basal and lateral unit of the Taubate Group comprising diamictite, polymictic conglomerate and massive mudstone with carbonate paleosoils of alluvial fan systems. Massive mudstone is laterally interbedded with cross-bedded sandstone of alluvial plains of braided rivers in the inner parts of the basins. Ankaramite lava-flows of Eocene age occur in the Casa de Pedra Graben (Volta Redonda Basin), intercalated in alluvial mudstone. In the central part of the Taubaté Basin there are claystone, organic-rich shale (locally oil-shale), and minor layers of dolomite related to a lacustrine environment of Oligocene age, named as Tremembé Formation, which also comprises sandstone at the borders of the paleolake. The uppermost part of the syn-rift sequence is mainly composed of sandstone, claystone and minor conglomerates of a fluvial meandering system of the São Paulo Formation.

The deformation phases involved reactivations along previous faults and subordinately the formation of new ones (Riccomini, 1989; Salvador and Riccomini, 1995; Riccomini et al., 2004). During the Neogene (Miocene) the central segment of the CRSB was under the action of a strike-slip regime, with NW-SE-oriented extension and local NE-SW-oriented compression. This event changed the rift architecture, generating local uplifts and noncylindrical folds, as observed in lacustrine deposits of Tremembé Formation (Riccomini, 1989; Takiya et al., 1990; Silva, 2007). The original rift depression was segmented by transverse NNW-SSE-oriented faults that generated structural highs related to transpression. Besides, these structures acted disconnecting the Taubaté Basin from São Paulo Basin, and reversed the course of the Paraíba do Sul River, from southwest to northeast, as a result of a headwater capture of the Tietê River (Riccomini et al., 2010). Sandstone and conglomerate of a fluvial braided system (Itaquaquecetuba Formation) were deposited in pull-apart basins 
developed over the structural high separating the São Paulo and Taubaté basins. The base level changed and restructured the Paraiba do Sul River drainage, especially in the central part of Taubaté Basin, resulting in erosion of Oligocene deposits, and the installation of a fluvial meandering system (Pindamonhangaba Formation), comprising conglomerate, sandstone, siltstone and claystone. After de sedimentation of Pindamonhangaba Formation there was a tectonic quiescence, with a deposition of colluvial and alluvial sediments, which are the result of relief remodeling caused by climate changes during the Quaternary (Riccomini, 1989).

Widespread Quaternary neotectonic features along the CRSB are related to a NW-SEoriented Late Pleistocene-Holocene compressive stress regime followed, successively, by an E-W- to NW-SE-oriented Holocene extension and an E-W-oriented compression (Riccomini et al., 2004). These deformations are clearly evidenced by stone-lines (Ab’Sáber, 1962) that are often intercepted by faults, indicating a recent tectonic activity (Riccomini et al., 1989).

During the NW-SE-compression, which occurred during the late Pleistocene to Holocene, the rift border faults were reactivated as strike-slip faults and reverse faults, whilst the activity of NNE-oriented faults generated structural highs, as Caçapava and Resende, separating the Paleogene sedimentary record into isolated basins. These faults intersect the fluvial deposits of the Pindamonhangaba Formation in the central part of the Taubate Basin, as well as the stone-lines (Riccomini et al., 1989; 2004).

From the early Holocene an E-W- to NW-ESE-oriented extension took place and it apparently shaped the sediment framework we know presently. It appears to be responsible for creating N-S-oriented valleys controlled by normal faults that intersects colluvial, alluvial and stone-line deposits aged from Late Pleistocene to Holocene (Salvador and Riccomini, 1995; Riccomini et al. 1989, 2004).

The last event, with an E-W-compressive character, occurred during the Holocene and is responsible for the reactivation of N-S-oriented faults as reverse faults, and created a 
widespread family of conjugate hybrid and shear joints in colluvial, alluvial and stone-line deposits (Salvador and Riccomini, 1995; Riccomini et al., 2004). This is the current stress regime in the region, as indicated by focal mechanism of earthquakes (Assumpção, 1992, 1998; Lima et al., 1997).

The stratigraphy and the evolution of stress fields in the central segment of the CRSB are summarized in Figure 2. 


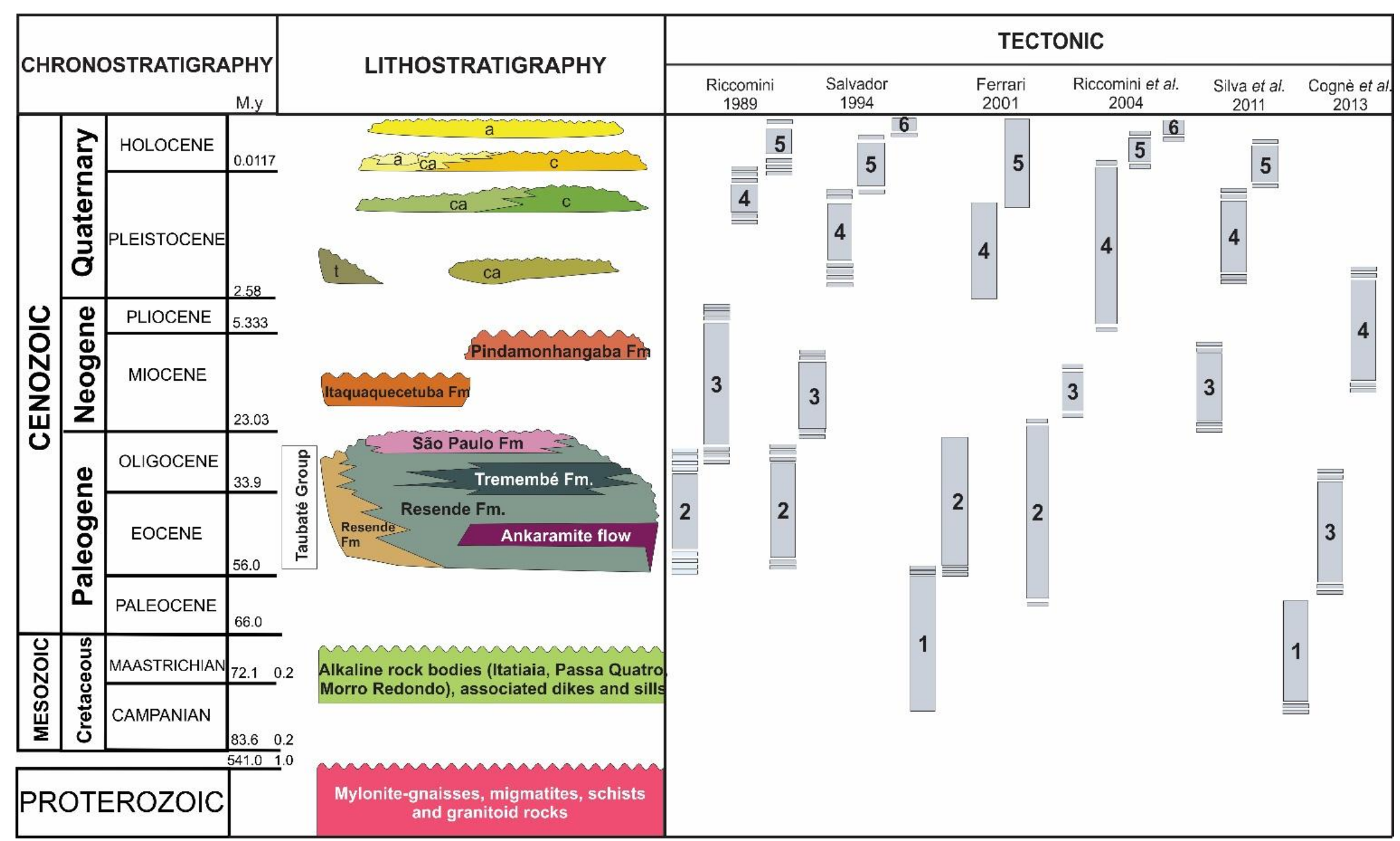

Figure 2 - Litho-chronostratigraphic column and tectonic setting of CRSB (modified from Riccomini et al., 2004; Silva and Mello, 2011; and Cogné et al., 2013). ca: colluvial-alluvial deposits; a: alluvial deposits; c: colluvial deposits; t: talus deposits. 1. Left-lateral transcurrence (NE-SW-oriented compression and NW-SE-oriented extension); 2. NNW-SSE-oriented extension; 3. Left-lateral transcurrence (NE-SW-oriented compression and NW-SE-oriented extension); 4. Right-lateral transcurrence (NW-SE-oriented compression and NE-SW-oriented extension); 5. NW-SE to E-W-oriented extension; 6. E-W-oriented compression. 
The Santos Basin evolution is related to the opening of the South Atlantic and to the events that generated and deformed the CRSB and consequently the Taubaté and Resende basins. Macedo (1989) pointed a correlation between the deformation of Santos Basin with tectonic pulses in the onshore continental area of southeastern Brazil, as indicated by turbidite deposits in Santos Basin. According to Meisling et al. (2001), the margin of southeastern Brazil was reactivated in three main phases that were related to three phases of Andean orogeny by Cobbold et al. (2001).

The first one occurred in the Late Cretaceous with exhumation of Serra do Mar, the second in the Paleogene, with further exhumation of Serra do Mar, alkaline magmatism and formation of Paleogene basins, as the Taubate Basin. The last one occurred during the Neogene, when Paleogene basins were inverted, and the supply of clastic sediments was diverted from Santos Basin to Campos Basin, and with the development of an anticline in Cabo Frio.

Chang et al. (2008) summarized the evolution of Santos Basin into a rift phase and a passive margin phase. During the development of the syn-rift phase, the stress was confined, creating crustal faults. The later phase developed with the lithospheric crust thinning partly, which generated the formation of faults with lower dip. In a third phase, a sag basin was formed, with the deposition of the main source rock of Santos Basin. From this phase on, it occurred an expressive evaporitic sedimentation, during the Aptian. After the evaporitic phase it was installed a clastic deposition in the proximal region and a carbonate sedimentation, in the deep area. During the passive margin phase, in the Albian, the continents were separated and a significant subsidence has occurred, allowing the sea incursion and the development of a carbonate platform. According to Macedo (1989), this thermal subsidence caused a tilting of the tectonic blocks. Alluvial and fan delta deposits in proximal areas of this platform indicate tectonic movements in the continental area, maybe related to a new uplift of Serra do Mar. 
The carbonate platform extinction occurred in the Cenomanian, and this carbonate section was already deformed by halokinesis. Two transgressive sequences drowned the carbonate platform, one of that responsible for the deposition of the main source rock of post-rift phase, which is related to second anoxic event of the Cretaceous. During the Late Cretaceous, three phases of progradation caused the coastline retreat. These sedimentary pulses might be related to tectonic movements in the continent, as the uplift of Serra do Mar. Also, this period is correlated with the alkaline magmatism in the region. An extensional regime is suggested by the register of basic volcanism in Santos and Campos basins during the Eocene, which may be related to the initial extensional phase that originated the CRSB (Macedo, 1989). In the top of the Cenomanian sequence in the Santos Basin is recorded a regional unconformity, over which two progradational sequences were deposited. According to Chang et al. (2008), the Cenozoic section of Santos Basin records two unconformities, one in the Oligocene and other in the Miocene. Yet, in the Eocene it was installed a lowstand system tract, allowing the formation of a big turbidite reservoir (Figure 3). 


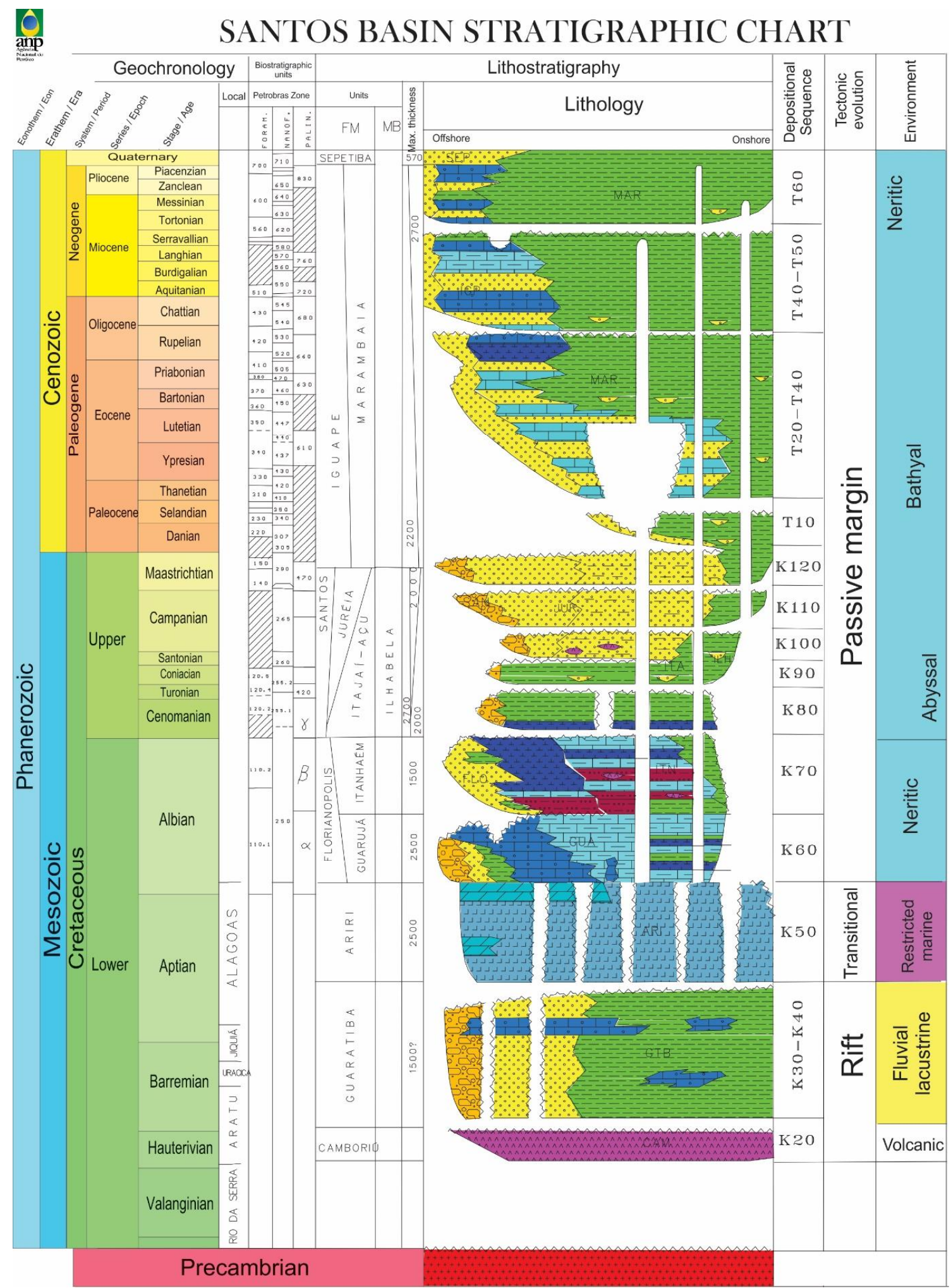

Figure 3 - Stratigraphic chart of Santos Basin (modified from Pereira et al., 1986 and Assine et al,. 2008, available in ANP - Agência Nacional do Petróleo: www.anp.gov.br; geological scale actualized according to Cohen et al., 2013) 
Assine et al. (2008) performed a sequence stratigraphic analysis using seismic lines and well data to demonstrate that depocenters in Santos Basin have migrated northeastwards during the Late Cretaceous into the Campos Basin, where the Tertiary section is well developed. It was evidenced that a Paleogene section is well developed in the north portion of the Santos Basin, and another important Paleogene and Neogene depocenter was in the southern portion of this basin. These depocenters were considered in terms of their relevance to understand the relation between the formation of reservoir rocks and the timing of petroleum generation and migration. The presence of transverse structures in the Santos Basin, related to different stress regimes during the Cenozoic, certainly represents a new element to be considered in the exploratory models for hydrocarbons. 


\section{MATERIALS AND METHODS}

\subsection{Field data}

Considering the controversies regarding the formation of transverse structures in Taubaté and Resende basins, the first step comprised the recognition of these structures in the previous papers and cartographic materials, selecting some of them as the most favorable to collect structural data in outcrops. Some of the available outcrops have a complex structural setting, being important to identify cross-cutting relationships between faults as well as the sedimentary deposits in order to have a relative age of these structures.

With the purpose of determining the chronology of faulting it was used the method described by Angelier (1994), which considers the age of the rock formations affected or unaffected by faults, the geometrical relationship between fault motions and the mechanical consistency. It was also used the cross-cutting relationship between identified slickensides (motion striae), because some faults were reactivated under more than one deformation event. Another way to describe the chronology of different events is the observation of the crosscutting relationship between striae, the younger cutting the older. However, it is not easy to observe due to the fact that older events might be usually masked or even erased by younger events, hampering the reconstruction of the movements.

Besides the collection of structural data during field survey, some outcrops were selected (especially because of their importance and data quality) for presentation as panoramas using the software GIMP 2 and Pandora script.

\subsection{Cartographic and seismic data}

In order to gather all the cartographic material as well as to analyze the digital elevation models, it was used the software Quantum GIS 2.6.1. Four ASTER images were selected, 
from The ASTER Global Digital Elevation Model (ASTER GDEM), which is a joint product developed and made available to the public by the Ministry of Economy, Trade, and Industry (METI) of Japan and the United States National Aeronautics and Space Administration (NASA). It is generated from data collected from the Advanced Spaceborne Thermal Emission and Reflection Radiometer (ASTER), a spaceborne earth observing optical instrument. The post interval is $30 \mathrm{~m}$ and the digital elevation model accuracy is between 7 and $14 \mathrm{~m}$. The hydrography was obtained from Instituto Brasileiro de Geografia e Estatística (IBGE, in www.ibge.gov.br) while the structural and geological maps were obtained from GEOBANK, from CPRM, Brazil Geological Survey, in geobank.cprm.gov.br.

The seismic profiles were obtained from Cogné et al. (2013). Only seismic profiles parallel to the Taubate basin axis were selected, as they supposedly can provide the better view of transverse structures.

Furthermore, the isopach maps of Santos Basin were obtained from Assine et al. (2008), in order to compare the depocenter migration in the Santos Basin with the deformation events observed in the Taubaté and Resende basins.

\subsection{Structural data analysis}

The right dihedra method of fault analysis, proposed by Angelier \& Mechler (1977), was employed to determine the paleostress fields. It is a graphical method that allows defining a reliable region where are the main stress axes from fault-slip data. Combining constrains from several faults related to each other allows the definition of $\sigma_{1}$ and $\sigma_{3}$ orientation fields that are compatible with different percentages of the faults (Orife and Lisle, 2006). The orientation of the $\sigma_{1}$ axis must belong to the compressional dihedron, whereas the orientation of the $\sigma_{3}$ axis belongs to extensional dihedron. Consequently, where two or more fault slips 
have occurred in the same stress regime, the main axes must belong to the corresponding dihedron for all the faults mechanism (Angelier, 1994).

If the slips on a set of faults all result from a single stress tensor, the stereogram should display $\sigma_{1}$ and $\sigma_{3}$ orientations regions compatible with $100 \%$ of faults (Orife and Lisle, 2006). In other words, in projection, all areas, which are not homogenous in terms of compressional and extensional dihedron, are progressively erased. As a result, the residual areas indicate the range of possibilities for the main stress axes (Angelier, 1994). Figure 4 summarizes the characteristics of right dihedral and the fault slip mechanism.

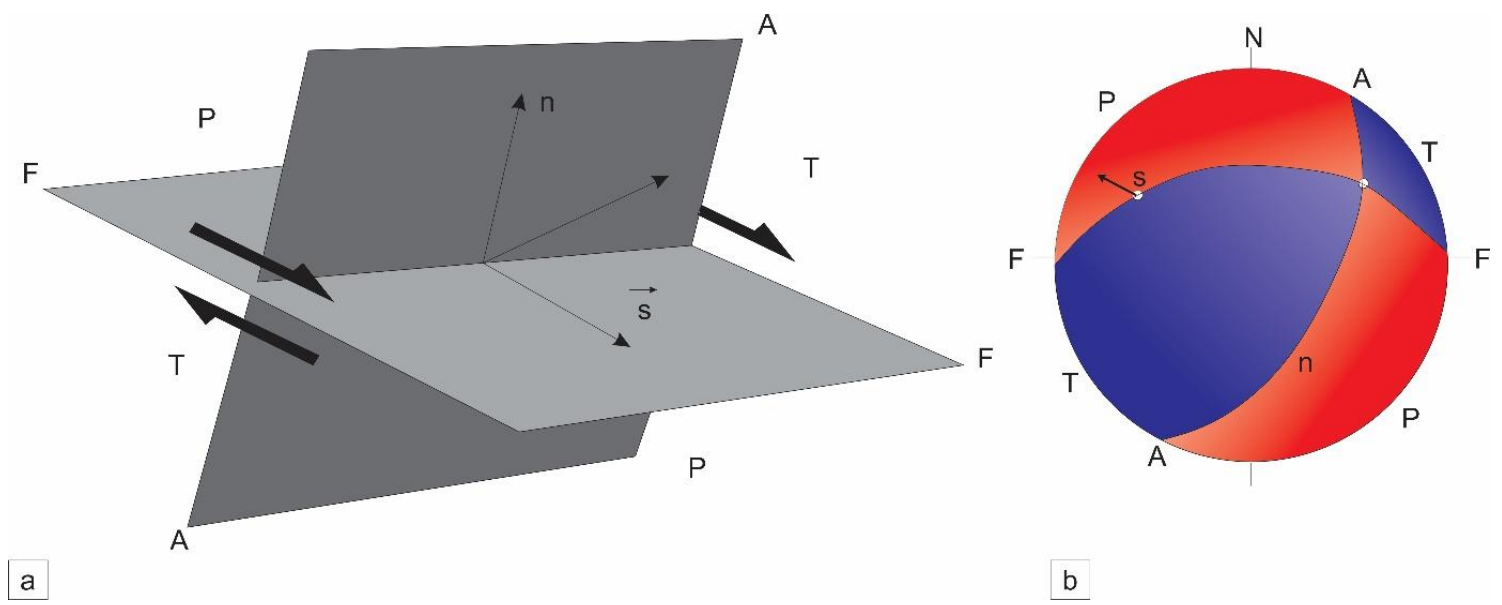

Figure 4 - Right dihedra and the fault slip mechanism. a) Perspective view. b) Stereogram, lower hemisphere. F: fault plane; A: auxiliary plane; n: normal to fault plane; s: unit slip vector in (a), reverse right-lateral slickenside lineation in (b); B: intersection of planes A and F; P: compressional dihedron; T: extensional dihedron (adapted from Angelier, 1994).

This method was applied making use of the software T-Tecto 3.0 (Žalohar and Vrabec, 2007) that enables classical and micropolar analysis of heterogeneous and homogeneous fault slip data using several different numerical method, including the Gauss method. It is based on the classical philosophy of fault-slip data inversion that consists of determining the stress tensor knowing the direction and the sense of slip on numerous faults of various orientations (Angelier, 1994). The Gauss method separates heterogeneous fault system in homogenous fault subsystem, and it was described by Žalohar and Vrabec (2007). The optimal solution for 
stress tensors that activated the observed faults is found by searching for the global and highest local maxima of the object function defined as a sum of compatibility functions for all slip-data.

Additionally it was used a Multiple-slip method visualization that is the sum of the compressional and extensional field for all faults, which leads to the common P and T fields.

The structural data collected was processed through the worksheet Tectonics FP 1.6.1 in order to adequate the information from faults and slickenside striae (strike $\mathrm{dip} / \mathrm{dip} / /$ trend/plunge and movement sense) besides the reliability height to T-Tecto 3.0 entry.

Moreover the structural stereograms were traced by T-Tecto 3.0, using the Wulf net (equal angle projections), lower hemisphere. 


\section{DATA AND INTERPRETATION}

\subsection{Seismic data}

The $178 \mathrm{~km}$ of 2D seismic profiles were acquired for PETROBRAS in the 1980's and were presented previously in Marques (1990), Carvalho et al. (2011) and Cogné et al. (2013). The earlier interpretation was done by Marques (1990), nonetheless the image resolution was poor. In Cogné et al. (2013) high-resolution images were presented, allowing the interpretations presented in this paper.

The location of interpreted longitudinal seismic profiles is presented in Figure 5.

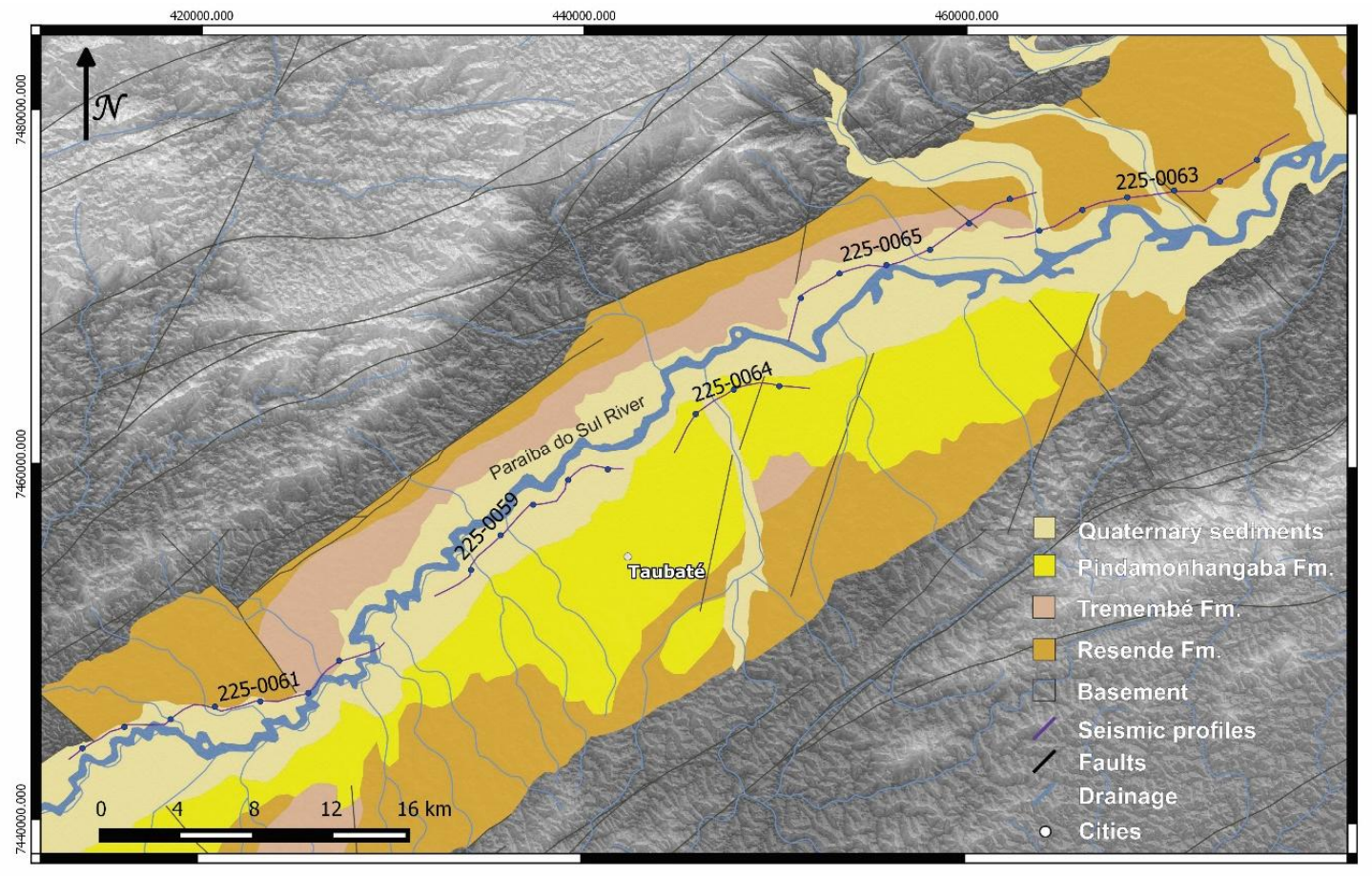

Figure 5 - Location of seismic lines over geological map (modified from Marques, 1990 and Perrota et al., 2005)

Marques (1990) identified four seismic units, comprising the basement, seismic unit A, seismic unit B and Taubaté Group. Cogné et al. (2013) divided the Taubaté Group into Resende and Tremembé formations. In this paper it has been adopted the stratigraphic succession from Marques (1990) and Cogné et al. (2013). 
The seismic lines were overlaid on geological map (Perrota et al., 2005) in order to guide the location in surface of Resende and Tremembé contacts. The top of Taubaté Group, corresponding to a regional unconformity overlain by the Pindamonhangaba Formation, was not considered by the reason that its thickness is less than $30 \mathrm{~m}$, which makes this unit not distinguishable on seismic profile due to scale proportions. The same occurs with colluvial and alluvial covers. Marques (1990) attributed a Late Cretaceous age for seismic units A and B and they are not exposed or drilled by wells. Nevertheless, research based on apatite and zircon-fission track indicates a post-rift period of exhumation during Late Cretaceous to Early Paleocene and the area where the central segment of the Continental Rift of Southeastern Brazil were installed was uplifted (Cogné et al., 2013). Furthermore, the first stages of development of the CRSB are from the Paleocene, which is recorded on the travertines of São José de Itaboraí Basin (Ricomini et al., 2004). Hence, it is possible to assume a Paleogene (up to Early Eocene) age to the units A and B in the Taubaté Basin.

In order to identify the different seismic units the following criteria were used:

- basement reflector unit: it is defined as the deepest strong and continuous reflector; the seismic energy returned weak below this surface except for the multiples reflections multiply reflected seismic energy, or any event in seismic data that has incurred more the one reflection in its travel path (Schlumberger Oilfield Glossary, 1998) - that occurs in some profiles with major significance; and the shape of the surface of basement that may be related to a paleorelief;

- reflector Unit A: it is identified by a strong reflector at the top and non-structured reflectors below; according to Marques (1990), Unit A is a basal unit, laid directly over the basement, which is not exposed, and is considered as coarse clastic sediments; 
- reflector Unit B: it is described as a strong reflector at the top and with some structuration below it and the reflectors below are thinly layered; according to Marques (1990), the Unit B is discordantly laid over Unit A, and it is composed of rhythmic mudstone at the base grading to sandy sediments at the top;

- Resende Formation: it is formed by strong and parallel reflectors that are sometimes deformed by faults;

- Tremembé Formation: it grades laterally, so it was identified using the geological map; at the base a strong reflector was used to mark the transition between Resende and Tremembé formations.

Marques (1990) identified some flower structures that indicates strike-slip faults. Cogné et al. (2013) did not found these structures in high-resolution seismic lines, assigned them as normal and reverse faults, as in this paper.

Seismic profile 225-0061

The segment covered by this line (Figure 6) was denominated by Marques (1990) as Eugênio de Melo Sub-basin, and it is delimitated by two structural highs. The structural high to the west was called Caçapava High, where basement crops out in the central part of the basin (Marques, 1990). 


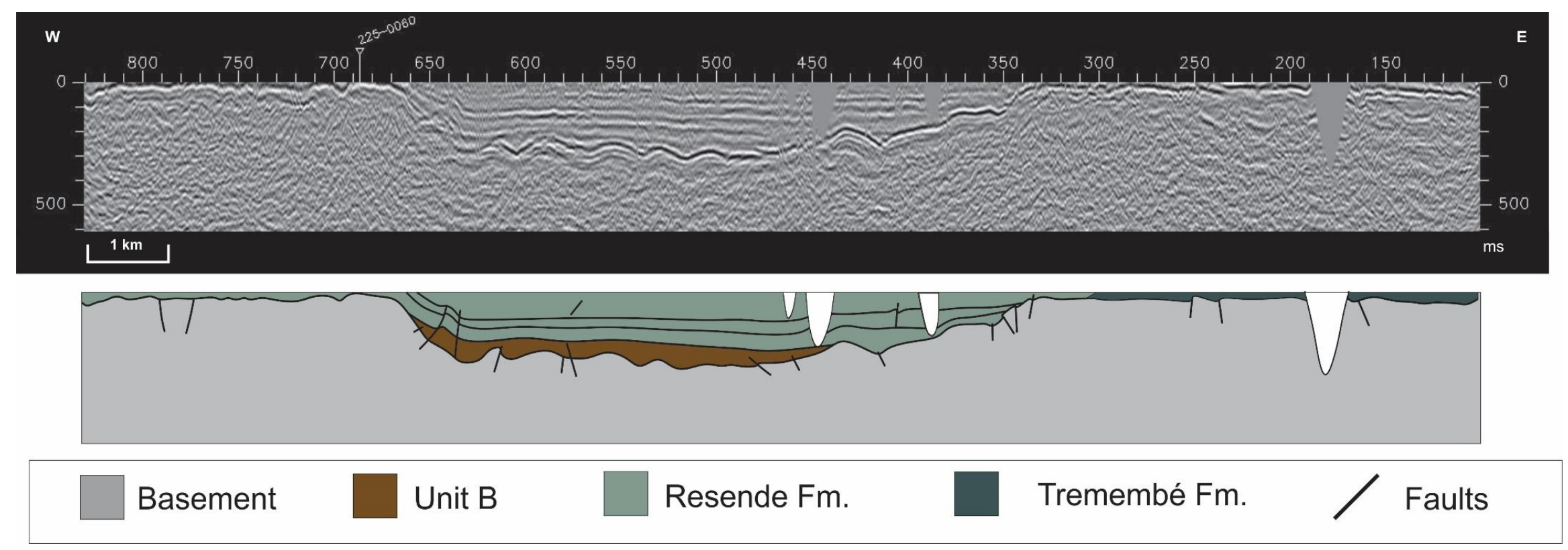

Figure 6 - Seismic profile 225-0061 (modified from Cogné et al., 2013) 
In the geological map, it is possible to observe that there are two major structures with NW-trending direction, which intercept the profile and are located in the structural highs.

These structural highs are faulted in seismic profile. The basement depth is approximately 300 ms TWT, but in the structural highs it is shallower, reaching no more than $8 \mathrm{~ms}$ TWT.

Moreover, it is deformed by pre- and post-sedimentary faults, and presents reverse and normal faults. Features like folds in the basement are also present, as previously recognized by Cogné et al. (2013).

Laying over the basement in an erosional contact is the Unit B. In this profile was not possible to recognize the Unit A.

The upper reflector unit is the Taubaté Group, formed by the Resende and Tremembé formations. The contact between these two units is lateral and was traced based on geological map. In the seismic profile it was not possible to recognize any syn-sedimentary fault. All faults are post sedimentary and present normal character.

\section{$\underline{\text { Seismic profile } 225-0059}$}

The segment of Figure 7 was denominated as Quiririm Sub-basin by Marques (1990). According to geological map, the unit exposed at the surface is the Tremembé Formation. The basement overtakes $500 \mathrm{~ms}$ TWT deep in some areas, and it is highly deformed by normal and reverse faults. In this profile, the Unit B rests directly over the basement and there is no register of Unit A. The sedimentary pack formed by Unit B, Resende and Tremembé formations is intersected by faults, especially at SW. These structures are very steep and present normal character. The thickness of sedimentary units seems to decrease to NE while the basement becomes shallower. 

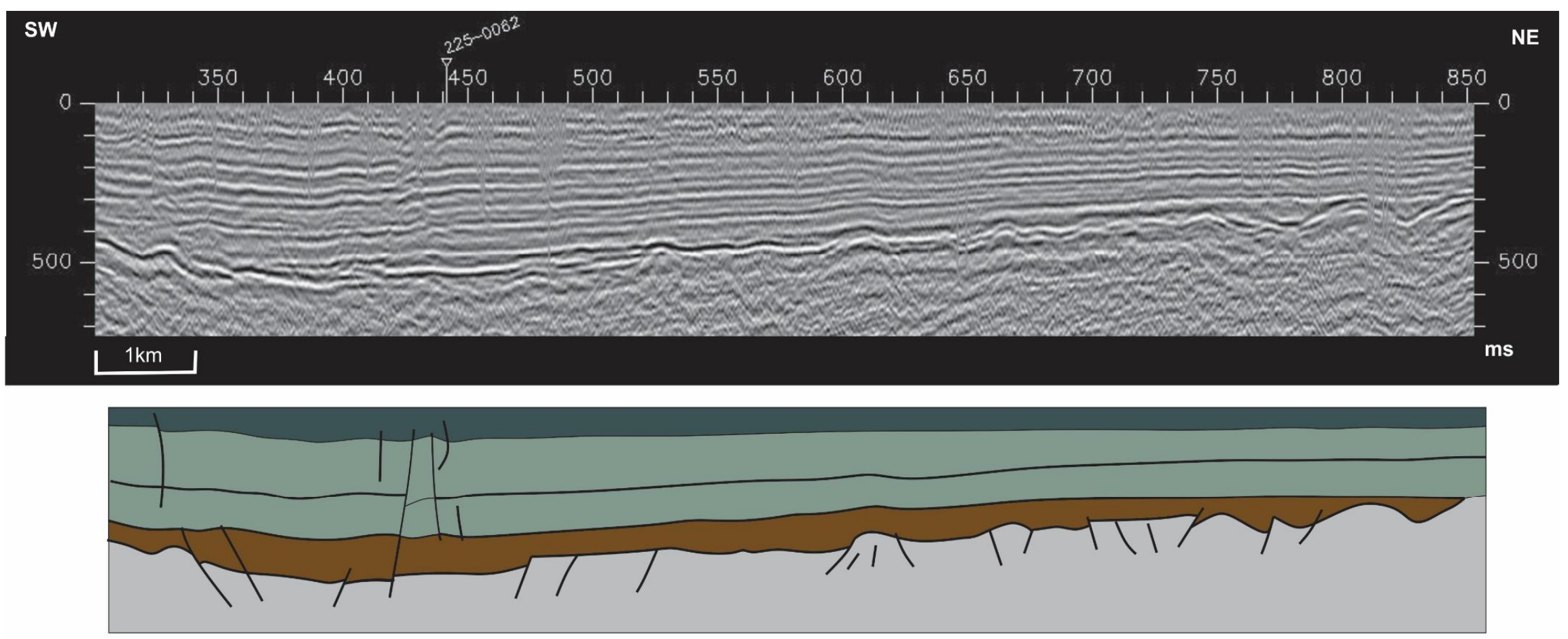

\begin{tabular}{|l|l|l|l|}
\hline Basement & Unit B & Resende Fm. & Tremembé Fm. $\quad$ Faults \\
\hline
\end{tabular}

Figure 7 - Seismic profile 225-0059 (modified from Cogné et al., 2013) 
Seismic profile 225-0064

In Marques (1990) this profile comprises the Capela do Socorro High (Figure 8), later denominated as Pindamonhangaba high by Fernandes (1993), separating the Quiririm and Roseira sub-basins. According to Riccomini. (2004), this high corresponds to an anticline trending NW-SE.

Evaluating the sedimentary succession, there is no Unit A, and the Unit B is immediately laid over the basement, with depth up to $300 \mathrm{~ms}$ TWT. The Unit B and the Resende Formation are thinner over the structural high when compared to the adjoining areas. The superficial unit in the geological map is the Pindamonhangaba Formation. Nevertheless, it is not visible in the seismic scale, thus it was represented the formation bellow with thickness consistent with the seismic scale.

According to geological map, there is a NNE-oriented fault that intercepts this profile between 300 and 400 and might be associated to the fault set located at 350 . This fault presents a clear variation in thickness of Unit B and Resende Formation, the former thicker to the west and the latter thicker to the east, which suggests a strike-slip movement. Most faults that are deforming the sedimentary pack are normal in the vertical section, although there are some faults with reverse components. 

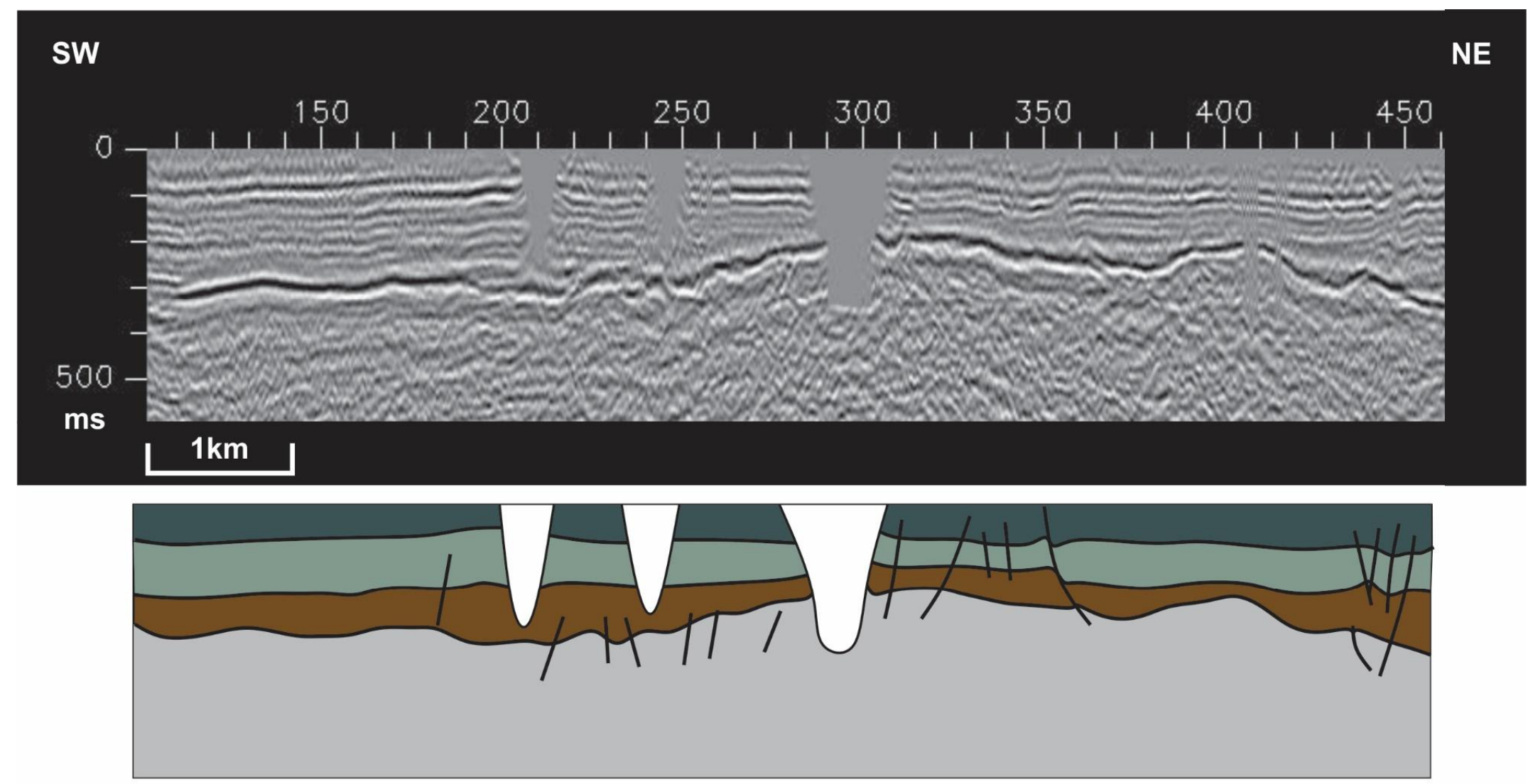

\begin{tabular}{|l|l|l|l|}
\hline Basement & Unit B & Resende Fm. & Tremembé Fm.
\end{tabular}

Figure 8 - Seismic profile 225-0064 (modified from Cogné et al., 2013) 
$\underline{\text { Seismic profiles } 225-0065 \text { and 225-0063 }}$

The area crossed by these two profiles corresponds to the Roseira Sub-basin (Marques, 1990), and there is some overlap between the two profiles (for location see Figure 5). All the seismic units are present in these profiles, and this is the only sub-basin that includes the Unit A, the oldest in the Taubate Basin. In the seismic profile 225-0065 (Figura 10), the sedimentary pack is very deformed. Most faults are intercepting all units, including the basement, which depth is up to $700 \mathrm{~ms}$ TWT. In these segments it is possible to observe the major depth registered in the studied sections in the Taubaté Basin.

The structures are very steep, and dip at times to SW and so to NE, and can be normal or reverse. In the geological map, a major NNW-oriented fault intercepts this profile at 600 and it may be related to the fault set between 600 and 700. Another major fault is identified in the geological map, but it not intercepts the profile. It is a NNE-oriented fault that may be covered by Quaternary sediments, so it is possible that it intercepts the profile. A fault set at 400 could be related to this NNE-oriented fault. Most faults apparently end before intercepting the Tremembé Formation probably due to the surface interference and consequently inadequate information on the first meters of these profiles.

The seismic profile 225-0063 (Figure 9) presents the basement highly deformed although the sedimentary pack is intercepted by a few faults. A major NNW-oriented fault can be identified in the geological map and intercepts the profile 225-0063 at around 400. There are some fault sets between 350 and 450 that may be related to this fault. All units are identifiable, and it is possible to observe a sedimentary thickening from $\mathrm{W}$ to E. Unlike the profile 225-0065 the faults described in this profile do not intercept all units, being restricted to certain units. 

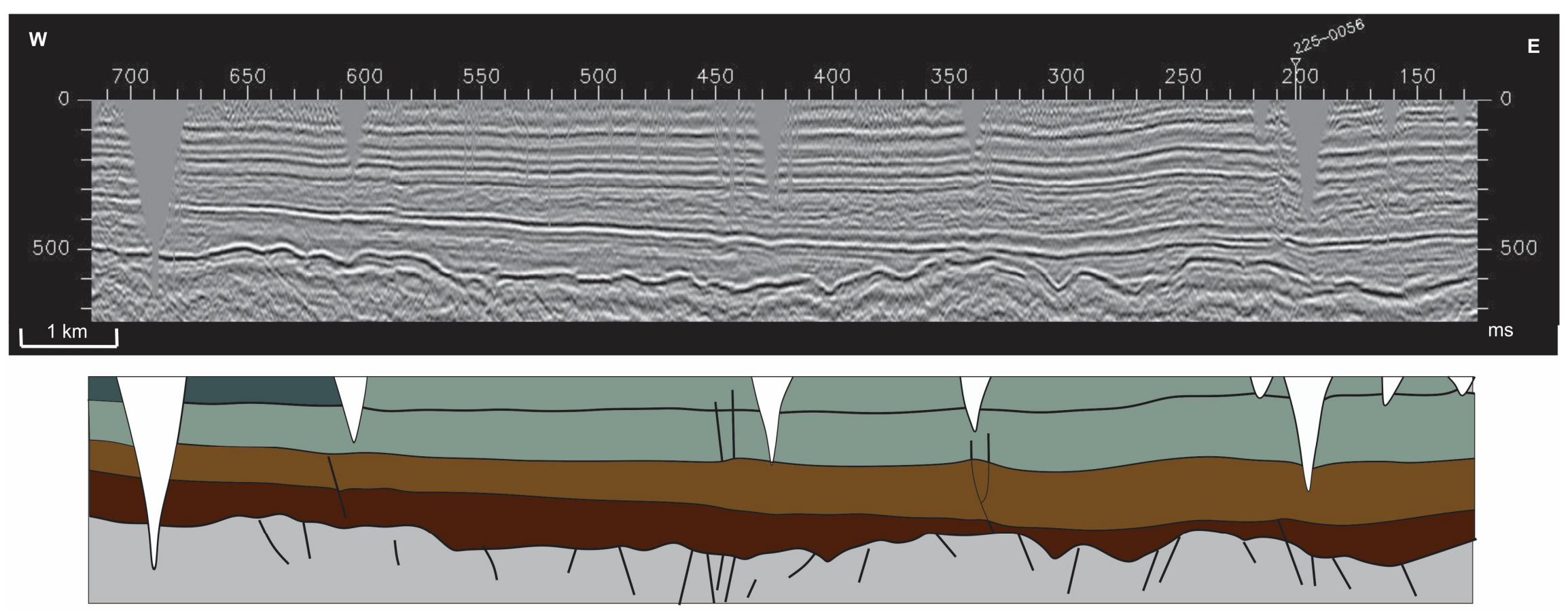

$\square$ Basement Unit A Unit B $\square$ Resende Fm. $\square$ Tremembé Fm. $/$ Faults

Figure 9 - Seismic profile 225-0063 (modified from Cogné et al., 2013) 

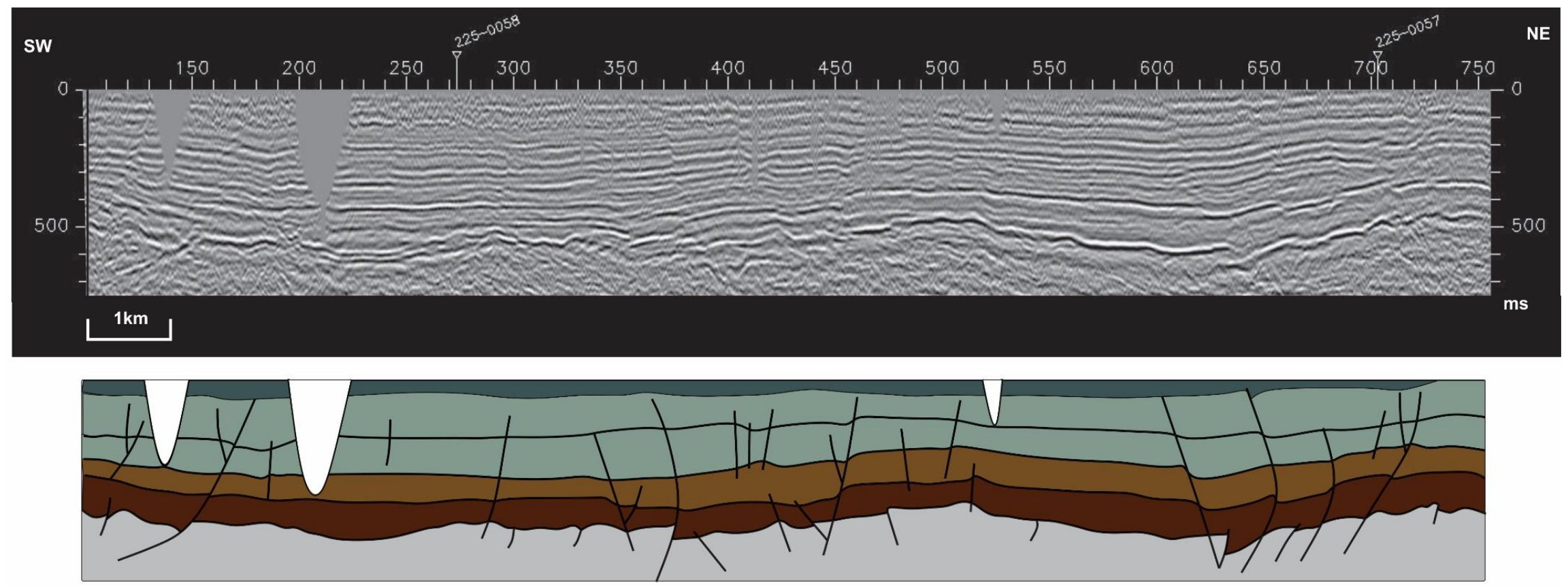

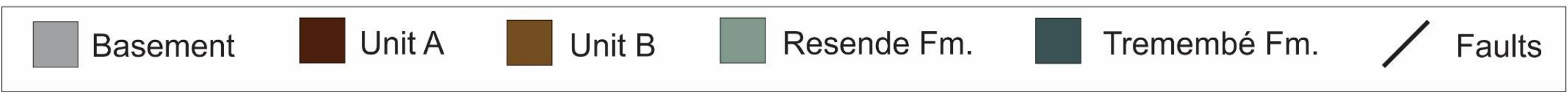

Figure 10 - Seismic profile 225-0065 (modified from Cogné et al., 2013) 


\subsection{Structural data}

Based on previous data and filed work, 17 outcrops with transverse faults were selected for structural analysis (see location in Figure 11). Of these, 11 are in the Taubate Basin, with a major concentration near the Caçapava Structural High, three in the region of separation between the São Paulo and Taubaté basins, three in the Resende Basin and one in the latest Cretaceous Itatiaia alkaline massif (northwest of Resende Basin).

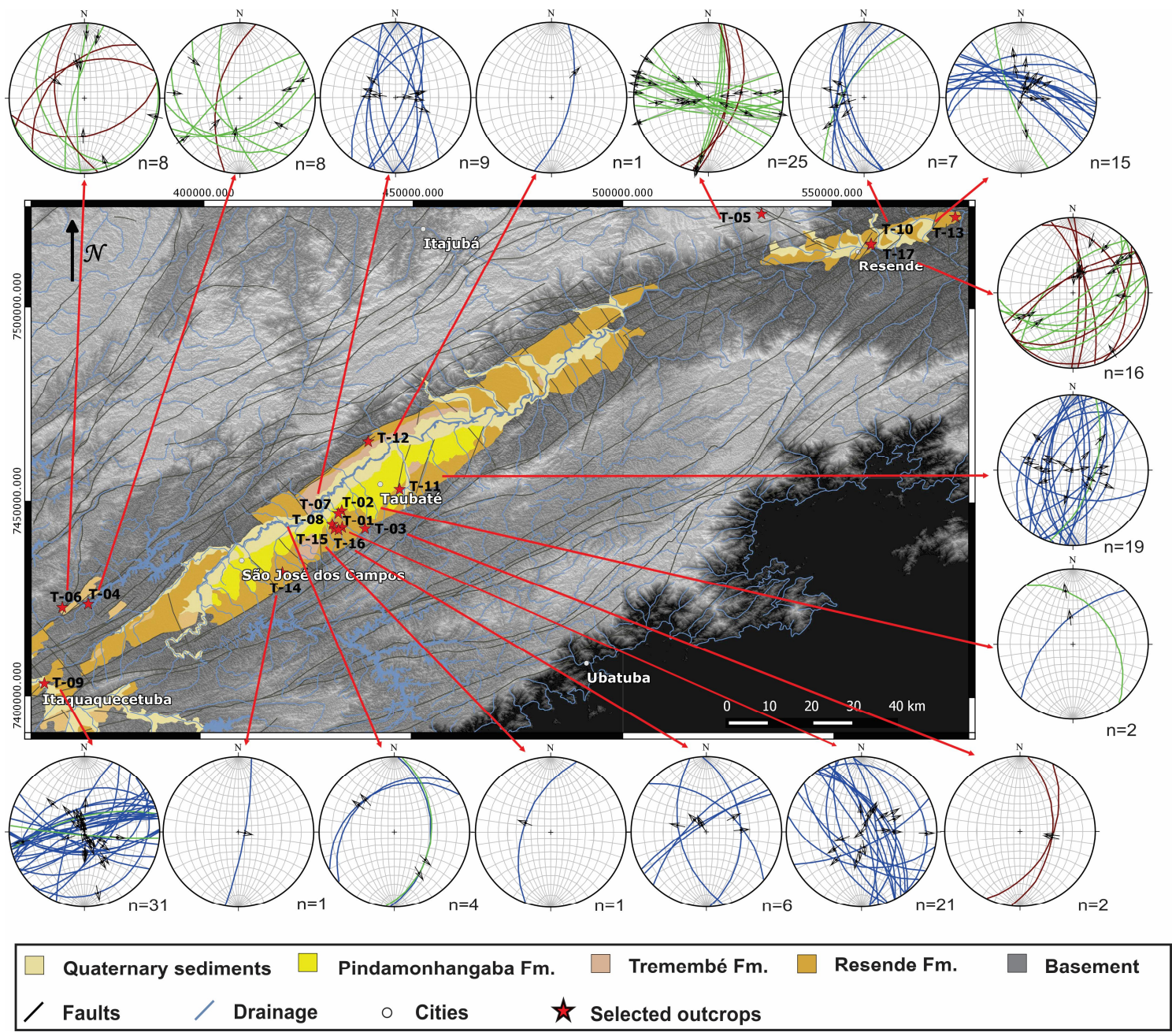

Figure 11 - Location map of selected sites for structural analysis. In the stereograms: blue line - normal faults; brown line - reverse faults; green line - strike-slip faults; arrow -striae (geological and structural map from GEOBANK; adapted from Perrota et al., 2005 and Leite et al., 2004) 
Fault-slip data inversion and paleostress determination using the software T-Tecto 3.0, and relationship between faults and sediments, allowed to identify five tectonic events as described below.

\section{NW-SE-oriented extension (Eocene - Oligocene)}

The NW-SE-oriented extensional event is related to the rift opening during the Eocene Oligocene. According to Riccomini (1989), this phase is correlated to the sedimentary filling of Taubaté Group (formed by Resende, Tremembé and São Paulo formations), and is well documented mainly in ENE to E-W-trending border faults, which follow the structural direction of ancient shear zones of Precambrian basement. This fault system is widespread in the central segment of CRSB.

An outcrop previously studied by Cassini (2011), at the NE boundary of Resende Basin, site T-13 (Figures 12 and 13), presents E-W to NW-SE-oriented syn-sedimentary normal faults transverse to the Resende Basin axis. Some of these faults are low-angle normal faults. Individual throw ranges from a few centimeters up to some decimeters. There is a NNW-SSEoriented oblique strike-slip with a vertical displacement of about $1 \mathrm{~m}$.

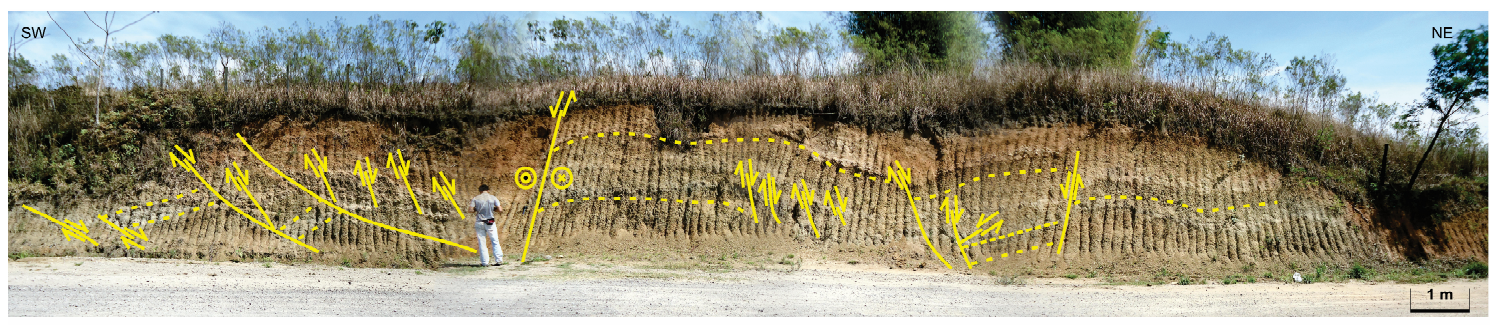

Figure 12 - Outcrop of site T-13. Most of faults are normal and syn-sedimentary. The rocks of Resende Formation are folded and intercepted by an oblique strike-slip fault, related to a later deformational event.

The mudstone, conglomerate and sandstone of Resende Formation are deformed by faults and folds. Clay injection were observed along some normal faults. All the normal faults were considered syn-sedimentary, as the faults do not crosses the upper layers (Figure 13). 


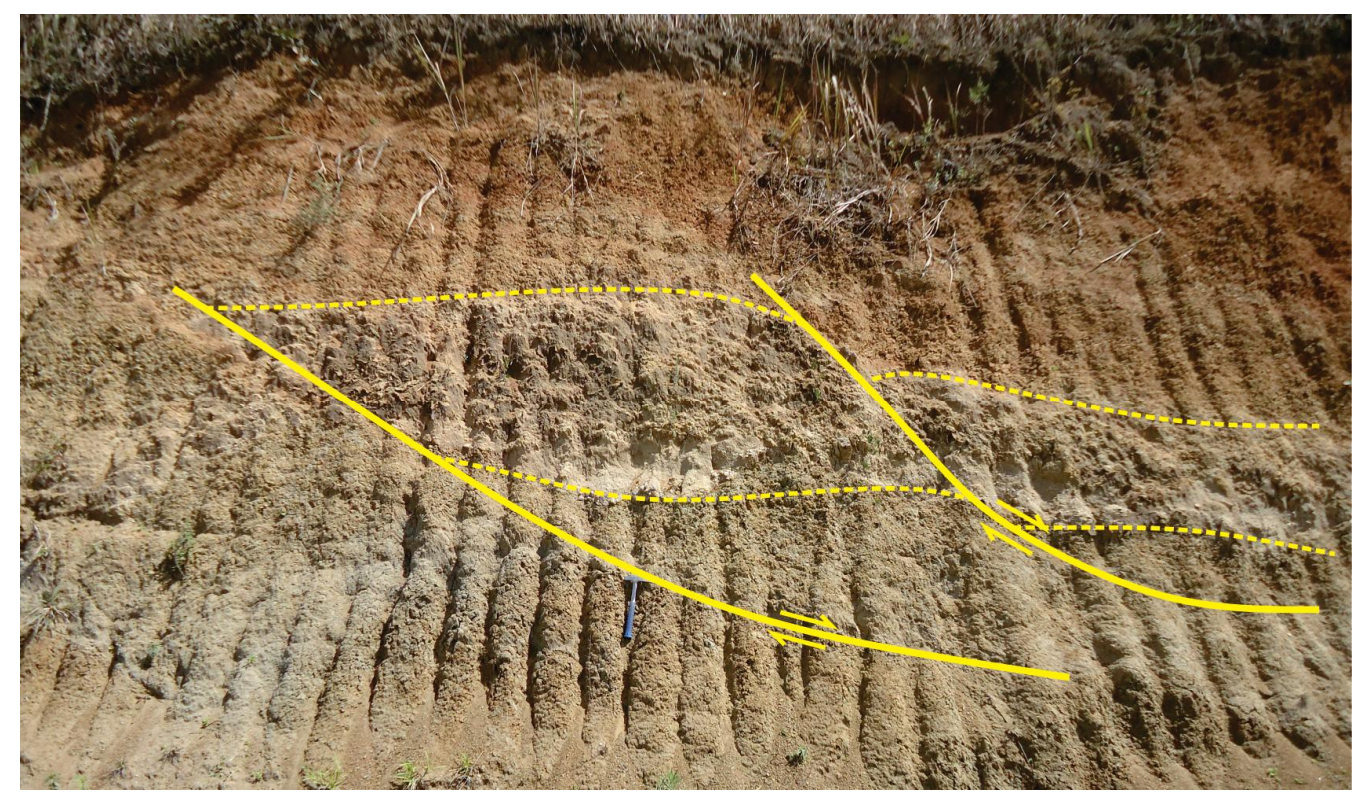

Figure 13 - Site T-13: detail of a low-angle normal fault (hammer as scale)

The oblique strike-slip fault and the folds were interpreted as a later deformation, due to fact that either affect all the sedimentary succession. This section corresponds to the upper part of the Taubate Group as nearby the deposits of the Resende Formation are laterally interfingered with those of the São Paulo Formation.

Paleostress analysis of the population of normal faults indicates an extensional field trending NE-SW, with a vertical compressional field (Figure 14a).

At site T-12, in the north border of Taubaté Basin (Figures 11 and 14b), one NNESSW-oriented normal fault with a left-lateral strike-slip component was measured. The fault dips to SE, intercepts deposits of the Resende Formation and marks the tectonic contact between conglomerate of alluvial fan to the northwesthwest and and fluvial mudstone and sandstone to the southeast. The minimum throw is over $7 \mathrm{~m}$ and the fault presents a synsedimentary character as the sedimentary layers grow in thickness toward the footwall. This transverse fault is oblique to the NE-oriented master faults at this part of the Taubate Basin. 

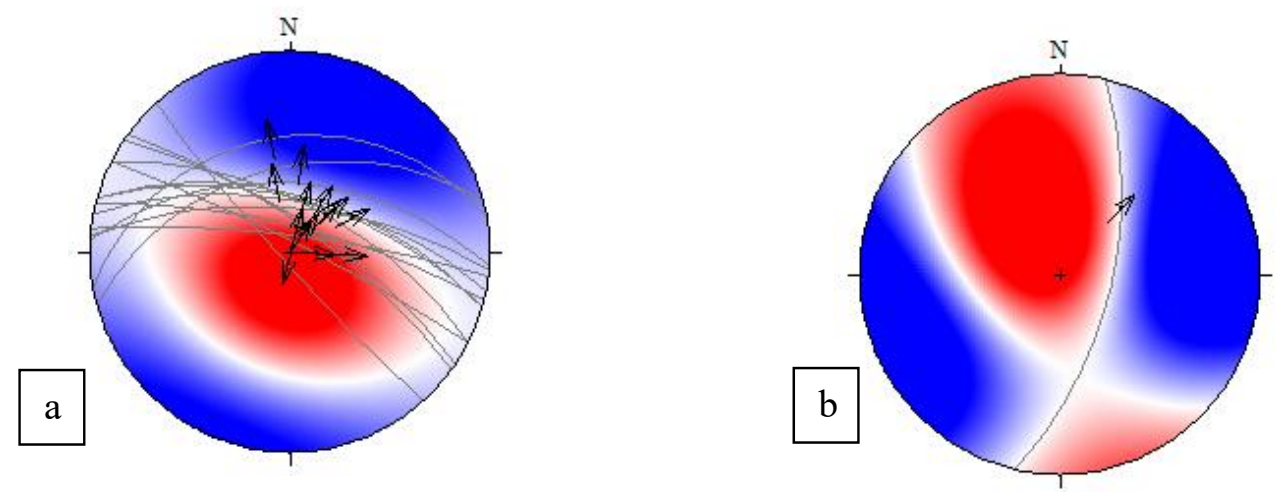

Figure 14 - NE-SW extensional field related to release faults. In: a) T-13; b) T-12. Blue is the extensional field while red is the compressional field

\section{$\underline{\text { NE-SW-oriented compression and NW-SE-oriented extension (Miocene) }}$}

The stress regime with NE-SW-oriented compression and NW-SE-oriented extension is related to the first deformational event in the CRSB. It corresponds to the event of left-lateral transcurrence proposed by Riccomini (1989). Two outcrops presented transverse faults associated to this deformational event, T-05 and T-09 (Figure 15).

The fault data of site T-05 were obtained entirely within the domain of the Late Cretaceous Itatiaia alkaline massif, northwest of the Resende Basin. This massif is mainly composed of nepheline syenite (Riccomini et al., 2005) and surrounded by Precambrian metamorphic rocks of Ribeira Belt. The continuity of these fault zones into the Resende Basin indicates that it is younger than the Eocene-Oligocene Resende Formation (Riccomini et al., 2004). A total of 25 faults were measured, most of them strike-slip, with two main directions, WNW-ESE and NNE-SSW, both subvertical. Among the NNE-SSW-oriented faults, three are reverse faults and three strike-slip. The WNW-ESE-oriented population of faults comprises mainly strike-slip faults. 
Paleostress analysis of this fault population indicates a NW-SE-oriented extensional field and a NE-SW-compressional field, in a transcurrent regime (Figure $15 \mathrm{a}$ ). According to Riccomini (1989), the WNW-ESE- and NNE-SSW-oriented structures acted as synthetic and antithetic strike-slip faults, respectively.

At site T-09, a sandy quarry in Itaquaquecetuba, next to the Arujá Structural High, NESW- to WNW-ESE-oriented predominantly normal faults and subordinately left-lateral strikeslip faults with normal components affect sandstone and conglomerate of the Miocene Itaquaquecetuba Formation. Some of these faults area clearly syn-sedimentary with individual throw of up to $4 \mathrm{~m}$. Paleostress analysis of this fault population indicates a NW-SE-oriented extensional field (Figure $15 \mathrm{~b}$ ).
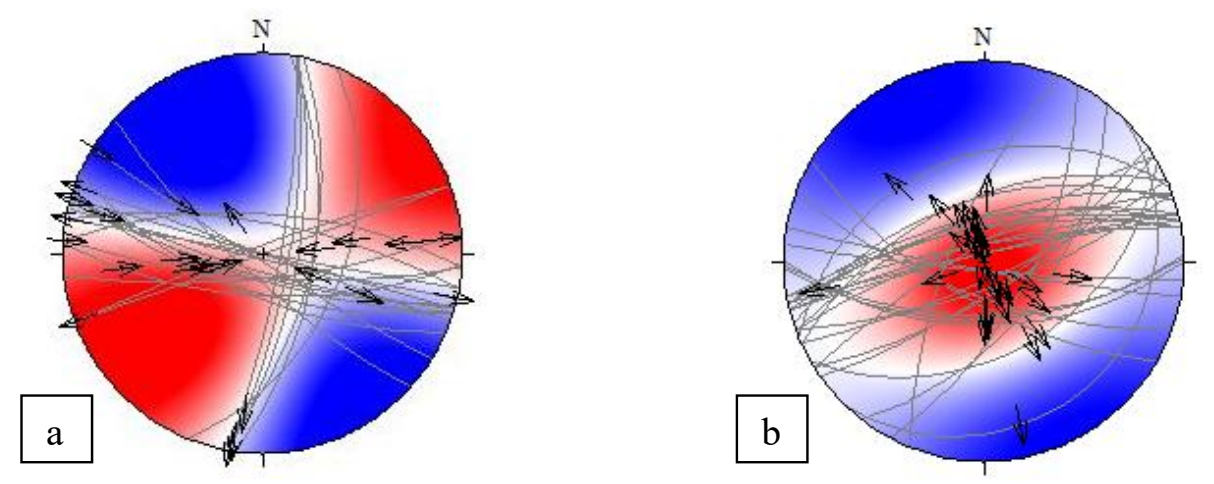

Figure 15 -NE-SW-oriented compressional paleostress field obtained from fault population of site T-05 (a) and T-09 (b). Blue and red are the extensional and the compressional fields, respectively.

NW-SE-oriented compression and NE-SW-oriented extension (Late Pleistocene - Holocene)

The stress regime comprising NW-SE-oriented compression and NE-SW-oriented extension corresponds to the second deformational event in the CRSB, or the event of rightlateral transcurrence proposed by Riccomini (1989). Transverse faults related to this event were studied at sites T-01, T-03 and T-06 (Figure 11). 
Site T-01 is a large road cut along the Carvalho Pinto highway, nearby the Caçapava High, in the central part of the Taubaté Basin. Fault population of this site includes predominantly NW-SE-oriented normal faults, with variations to N-S and WNW-ESE, with medium to high dips (up to subvertical) predominantly to NE and E. These faults truncate mudstones of the Resende Formation and, in two cases, sandy clayey colluvium of Quaternary age. Individual measured throw ranges from decimeters to more than $6 \mathrm{~m}$ (Figure 16). One NW-SE-trending subvertical fault shows two striae, the older suggesting a rightlateral strike-slip and the younger a normal movement. Paleostress determination (Figure 17a) indicates a clear NE-SW-oriented extension.
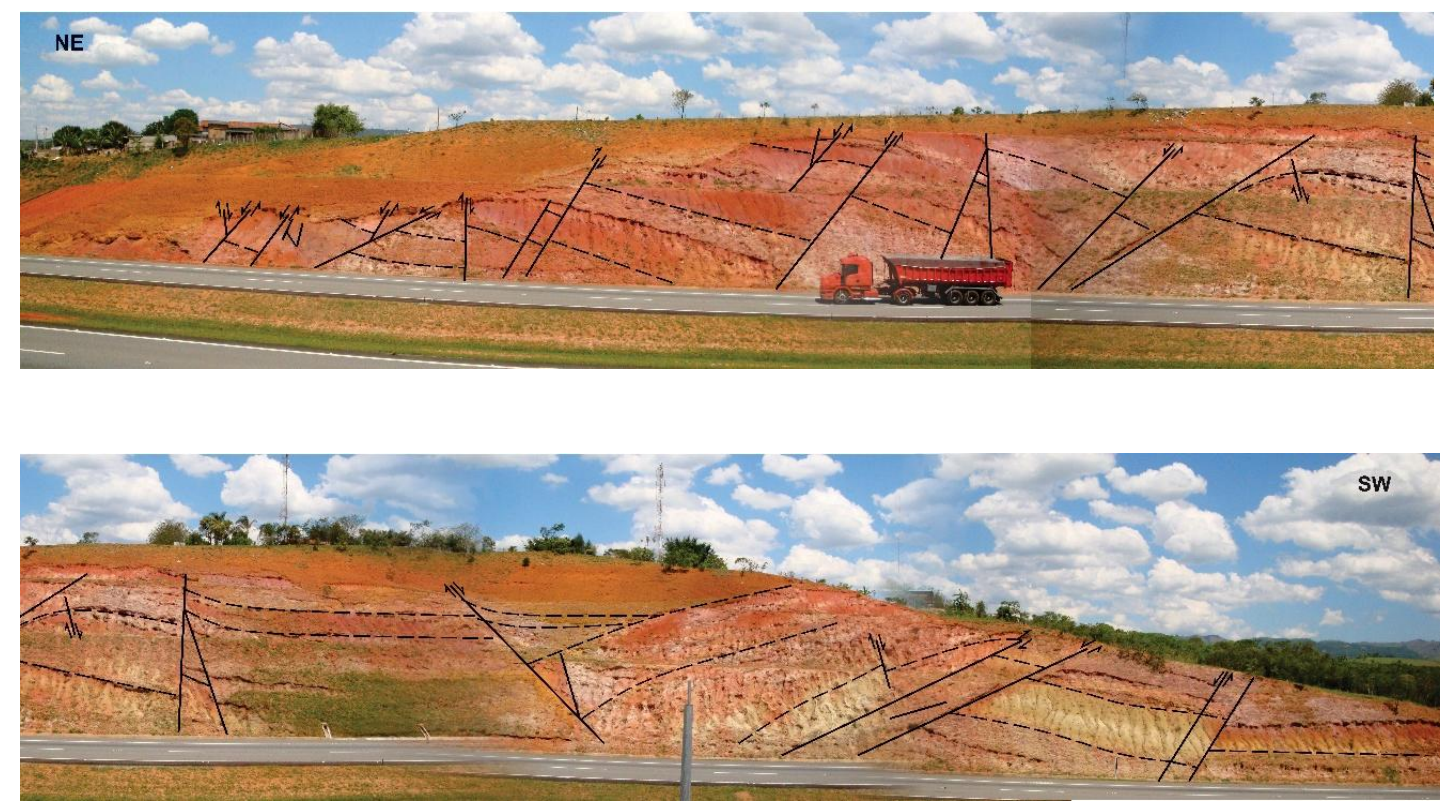

Figure 16 - Site T-01, road cut along the Carvalho Pinto Highway, located near Caçapava Velha. The outcrop is $80 \mathrm{~m}$ long approximately

Site T-06 is located at the southwestern part of the Taubaté Basin in an isolated occurrence of sedimentary rocks of the São Paulo Formation near to a reverse fault in the Precambrian basement rocks (Riccomini 1989). This deformation is probably related to the context of the Arujá Structural High that separates the São Paulo Basin from Taubaté Basin. Fault population comprises reverse and strike-slip faults with reverse components trending 
NW-SE and NE-SW (Figure 16b). NE-SW-trending faults are basement-controlled whilst NW-SE to N-S-trending faults are transverse structures. Paleostress determination (Figure 17b) indicates a clear NW-SE-oriented compression with a NE-SW-oriented extensional component.
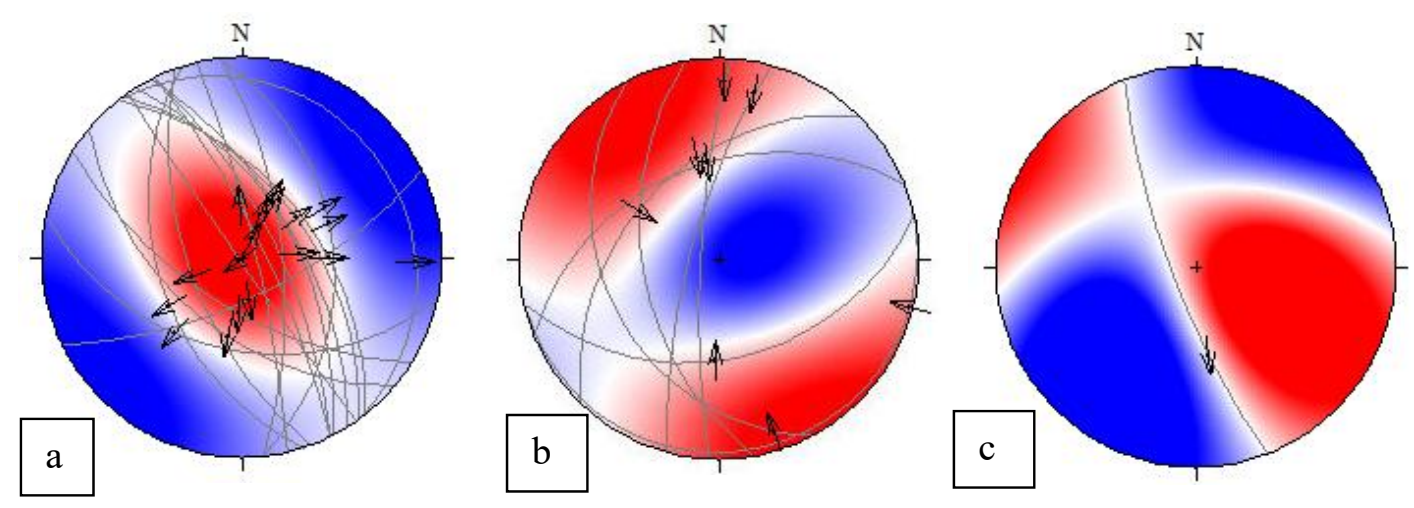

Figure 17 - NW-SE-oriented compression and NE-SW-oriented extension. In: a) T-01; b) T-06; c) T-13. Blue is the extensional field while red is the compressional field

The strike-slip fault in site T-13 at the northern border of the Resende Basin intercepts the normal syn-sedimentary transverse structures related to the rift installation, and are associated with folding. Paleostress determination (Figure 17c) clearly indicates NW-SEoriented compression and a NE-SW-oriented extensional, in a strike-slip regime of deformation.

\section{E-W to NW-SE-oriented extension (Holocene)}

According to Riccomini (1989) and Riccomini et al. (2004) the stress-field with E-Wto NW-SE-oriented extension has affected the colluvial and alluvial deposits of Pleistocene to Holocene age. It corresponds to the third deformational event in the CRSB. Transverse faults related to this event could be observed directly in seven places. With the exception of T-10 
site, located in the central region of Resende Basin, all other are in the central part of Taubate Basin.

Site $\mathrm{T}-10$ is located in the central part of the Resende Basin in the region of the Resende Structural High. NNW-SSE- to NE-SW-oriented post-sedimentary normal faults with moderate dip to the W intercepts deposits of the Resende and São Paulo formations, as well as stone line and colluvium. Individual fault throw reach more $5 \mathrm{~m}$. Paleostress analysis allowed the determinations of an E-W-oriented direction of extension (Figure 18a).

At Site T-14, south of São José dos Campos (Taubaté Basin), a N-S-oriented, subvertical normal fault affects mudstone of the Resende Formation with a minimum throw of $2 \mathrm{~m}$ (Figure 18b). An E-W-direction of extension can be deduced for this fault. Due the subvertical dip this fault probably results from reactivation of an older strike-slip fault.

Site T-11 is located southeast of Taubaté. It was studied by Riccomini et al. (1989) and comprises a set of predominantly N-S- to NNE-SSW-oriented conjugate normal faults with moderate to high dips. Individual fault throw reaches more than $8 \mathrm{~m}$ (Figure 18c). Faults are post-sedimentary and affects fluvial meandering deposits (alternate layers of sandstone and mudstone) of the Pindamonhangaba Formation as well as overlying stone-line and a sandy colluvium. Paleostress analysis pointed a general E-W- to WNW-ESE-oriented direction of extension for this fault population. Some of these faults are subvertical and terminates in negative flower structures.

Sites T-07, T-08, T-15 and T-16 are located near Caçapava, in the region of the Caçapava Structural High, Taubaté Basin. Site T-08 is a road cut at Presidente Dutra Highway and was studied by Riccomini et al. (1989). A set of NNW-SSE to NNE-SSW-oriented conjugate normal faults with moderate to high dips, and presenting individual throws from decimeters to more than $1 \mathrm{~m}$ affects fluvial deposits of the Pindamonhangaba Formation, 
stone-line and colluvium (Figure 18d). Site T-08, previously studied by Mancini (1995) is a road cut along the Caçapava to Caçapava Velha secondary road and comprises conjugate NESW and N-S-oriented normal faults with moderate dips affecting deposits of the Pindamonhangaba Formation (Figure 18e).

Sites T-15 and T-16 are located in the area of construction of a new airport (Aerovale) near Caçapava Velha. At site T-15 a normal fault trending NNE with moderate dip to WNW (Figure 18f), with a minimum throw of $4 \mathrm{~m}$, truncates mudstone and sandstone of the Resende Formation and controls a syn-tectonic deposition of a Holocene muddy to pebbly colluvium, as evidenced by the thickening of the colluvial deposit towards the fault surface (Figure 19). Site T-16 displays two families of normal faults, one trending NE-SW with moderate to high dips to NW and throws from 0.5 to $3 \mathrm{~m}$, and the other, transverse, trending N-S- to NW-SE (Figure 18g), with moderate dips and individual throws from 1 to more than $6 \mathrm{~m}$. Crosscutting relationship between the two families suggests that they are conjugate ( $v . g$. Caputo, 1995). These faults truncate sandstone and mudstone of the Resende Formation as well as overlying stone-line and sandy-clayey colluvium (Figures 20 and 21).

Paleostress determinations indicate a general E-W- (sites T-07 and 16) to WNW-ESE(sites T-15 and 16) oriented direction of extension for the analyzed faults.
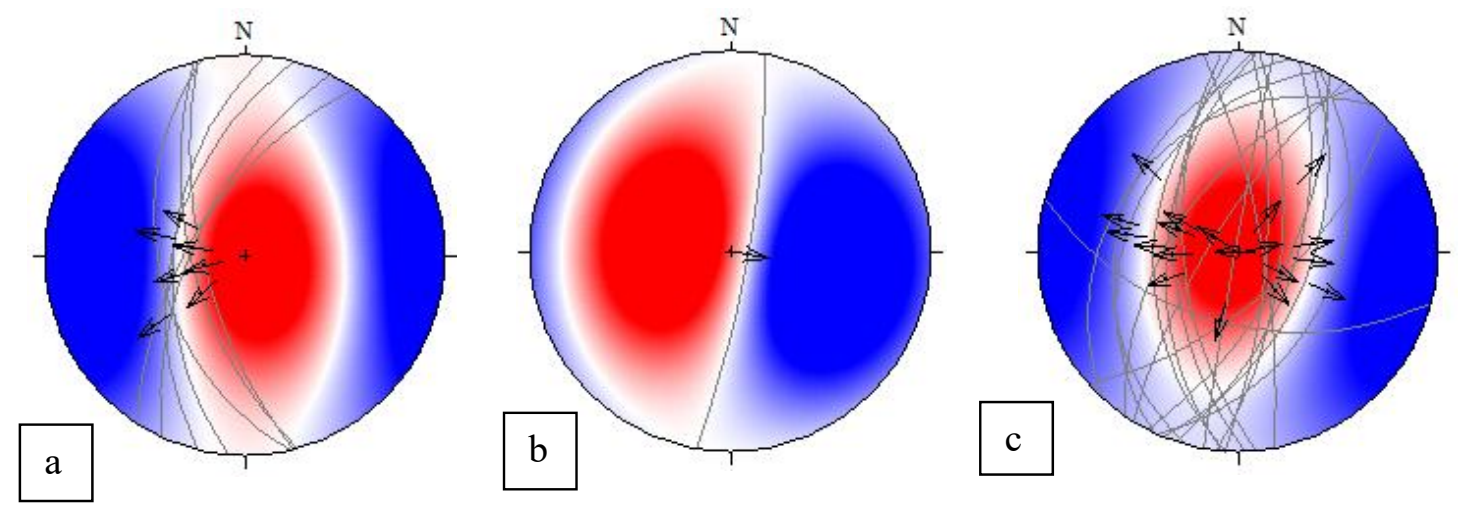

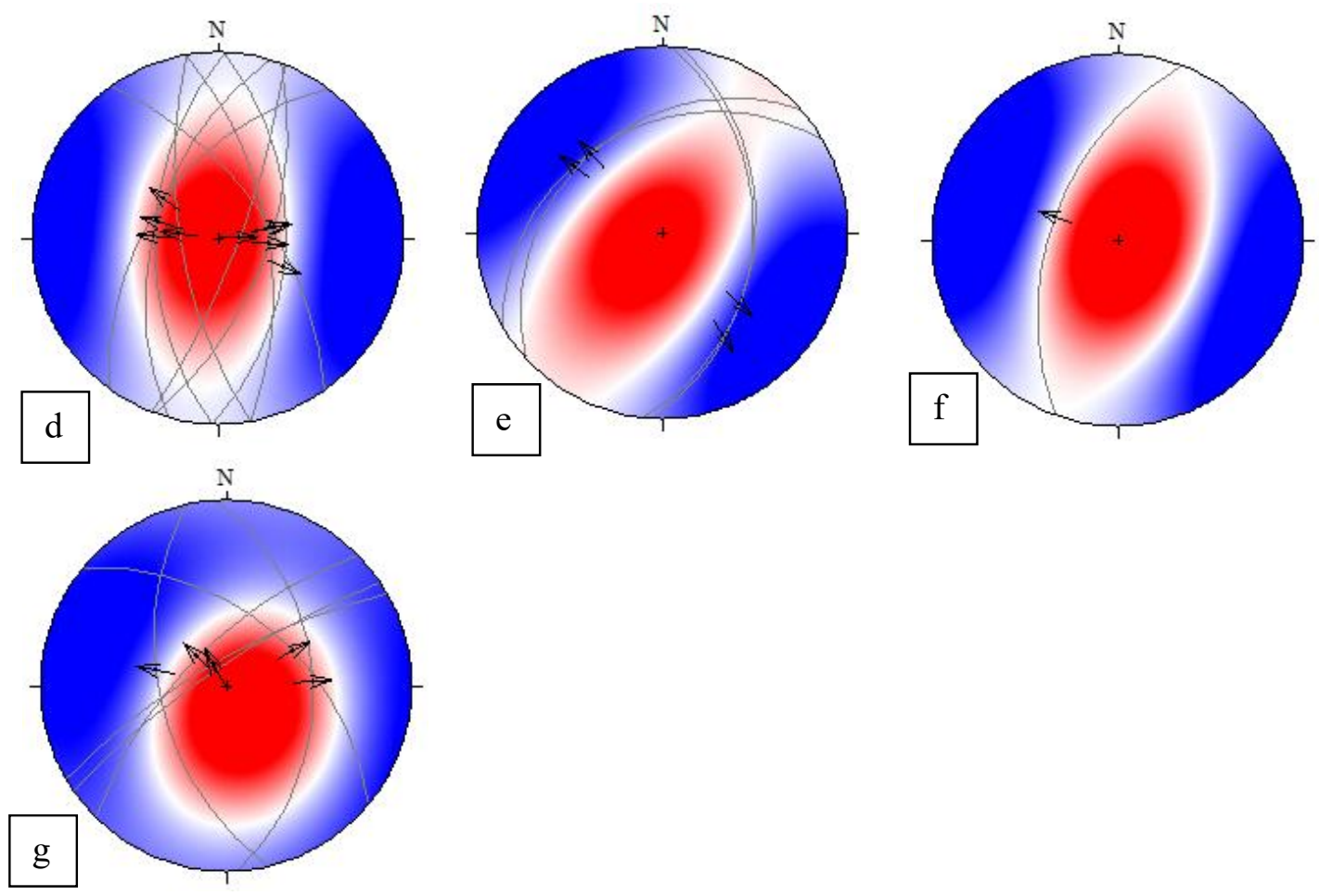

Figure 18 - E-W- to NW-SE-oriented extensional field. In:a) T-10; b) T-14; c) T-11; d) T-07; e) T-08; f) T-15; g) $\mathrm{T}-16$. Blue is the extensional field while red is the compressional field.

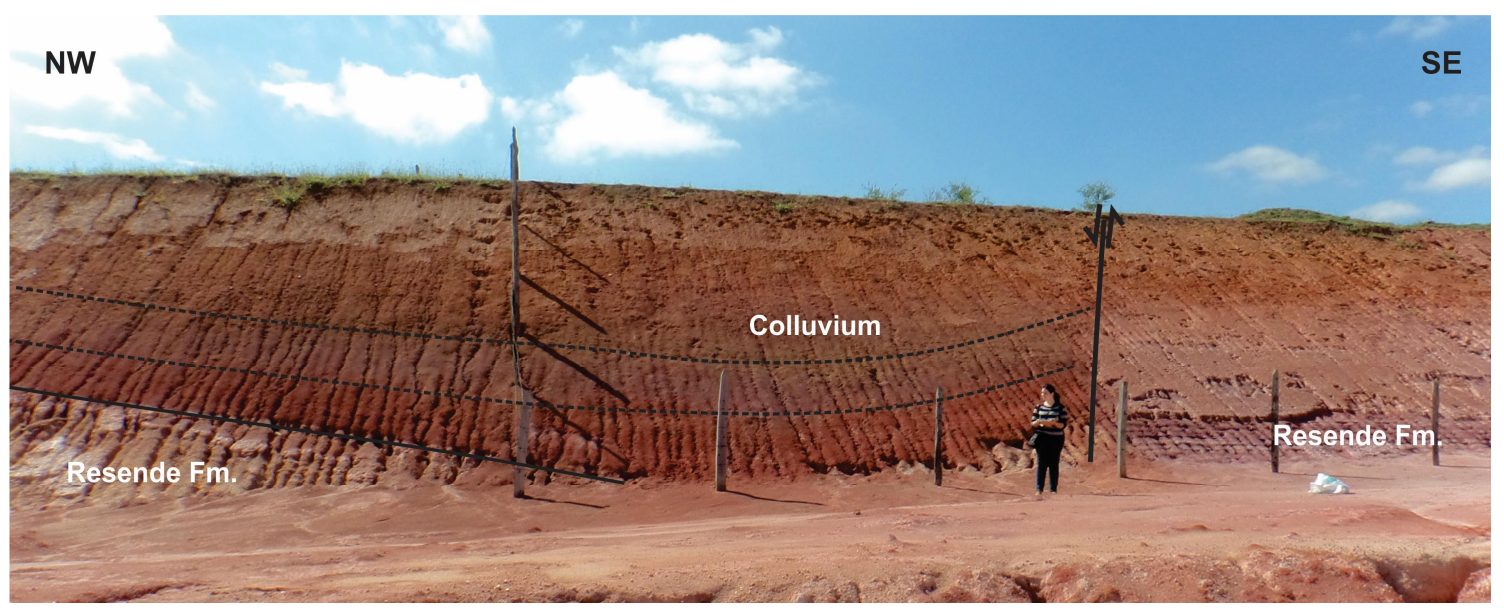

Figure 19 - NNE-SSW-oriented transverse normal fault that intercepts mudstone and sandstone of Resende Formation and present a syn-tectonic deposition of a muddy colluvial deposit site T- 15 . 


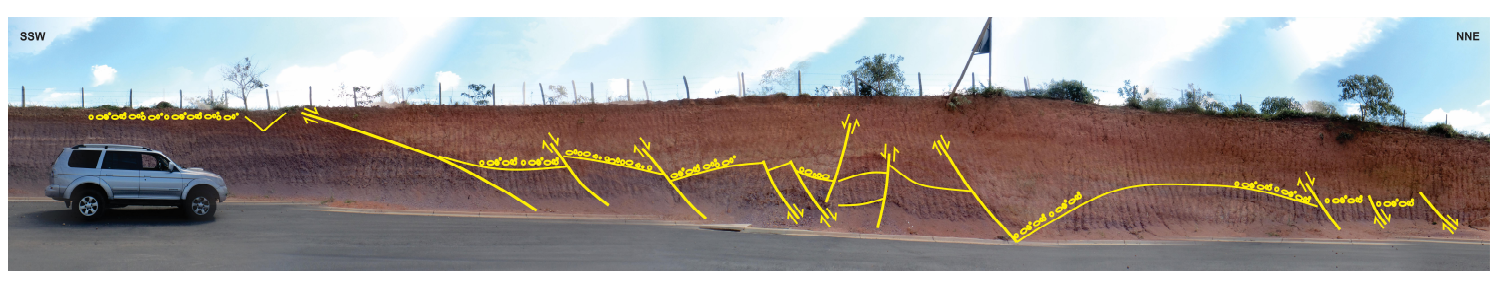

Figure 20 - Outcrop T-16. Deposits of Resende Formation, stone-line and colluvium intercepted by normal faults. Little circles represent the stone lines. The outcrop is $40 \mathrm{~m}$ long.

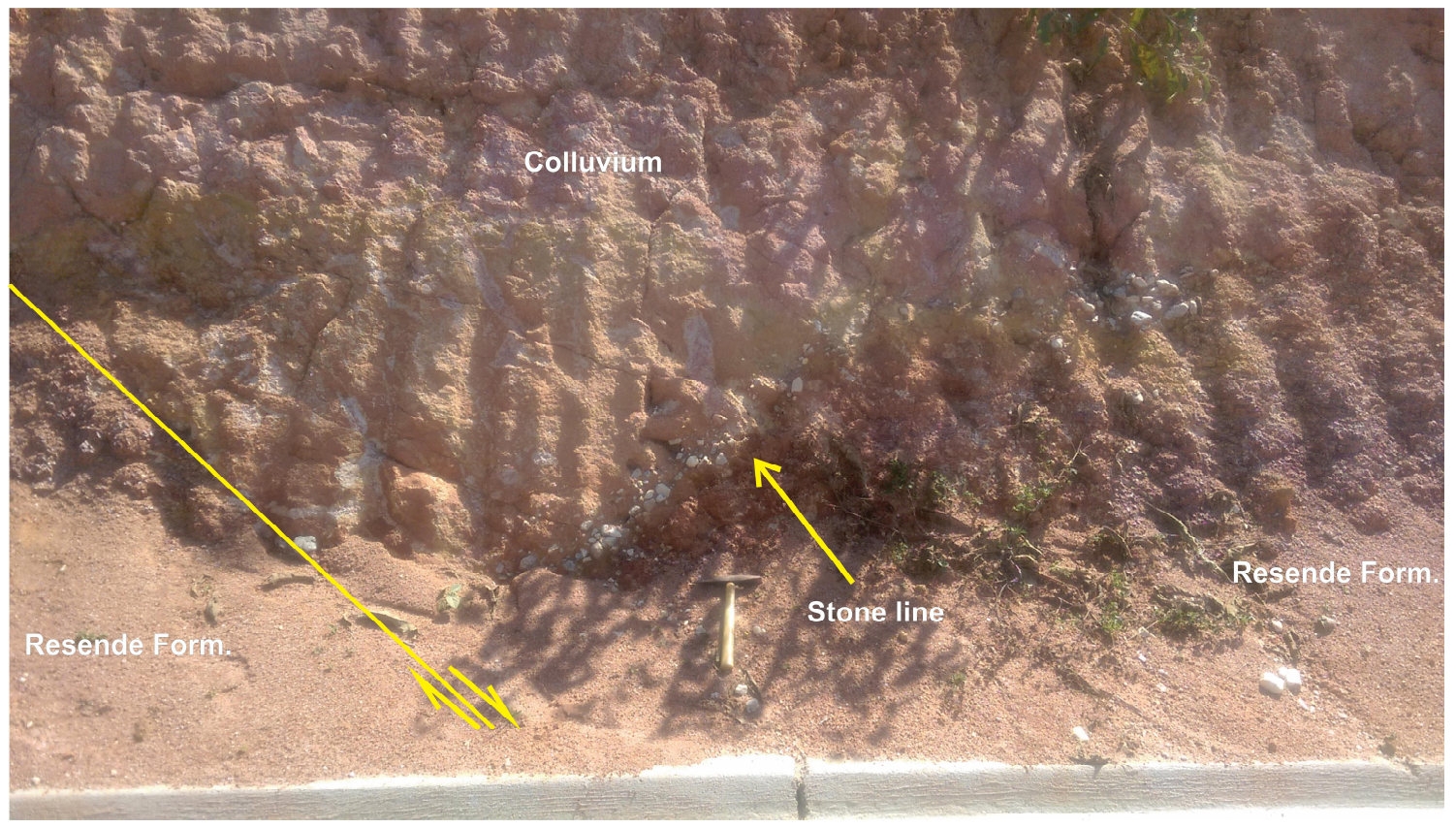

Figure 21 - Detail of a NW-SE-trending normal fault deforming stone lines at site T-16.

\section{$\underline{\text { E-W-oriented compression (current stress-field) }}$}

The last deformational event is related to an E-W-oriented compression (Salvador and Riccomini, 1995). Transverse faults related to the E-W-oriented compressional field were studied in four sites.

Site T-04 is situated along the Jaguari Fault Zone (Figure 11), a Neoproterozoic shear zone that limits an isolated occurrence of sedimentary deposits of the São Paulo Formation in the southwestern part of the Taubaté Basin. All faults of this site have reverse component of 
movement and show variable strikes and low to high dip angles at this basin (Figure 22a).

Paleostress analysis indicate an E-W-oriented compression.

Sites T-02 and T-03 were previously studied by Mancini (1995) and are located in the context of the Caçapava Structural High (Figure 11). Site T-02 comprise two faults affecting deposits of the Pindamonhangaba Formation. One is NW-SE-oriented, left-lateral strike-slip, and the other a NE-SW-oriented, right-lateral strike-slip fault, both with normal components and moderate dip to NE and NW, respectively. Site T-03 comprises two N-to-NNE-oriented reverse faults, with moderate dip angles to the $\mathrm{E}$, affecting deposits of the Resende Formation (Figures 22b, c). Faults of these sites are compatible with an E-W-oriented compression.

Site T-17 is located in the Resende Structural High and was previously studied by Riccomini (1989) and Riccomini et al. (1989) (Figure 11). It comprise thrust and strike-slip faults with reverse components, with variable orientations and individual throws from some centimeters to more than $1 \mathrm{~m}$. They affect deposits of the São Paulo Formation, fluvial terraces, stone-line and colluvium.

Paleostress analysis pointed a general E-W- to WNW-ESE-oriented direction of compression for this fault population (Figure 22c).
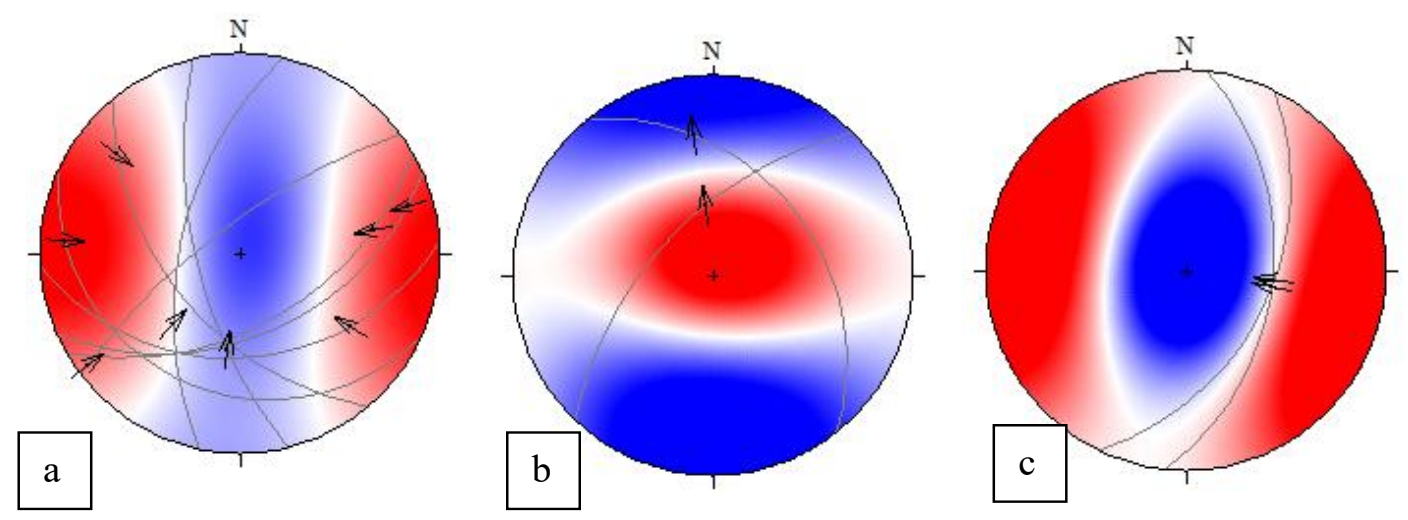


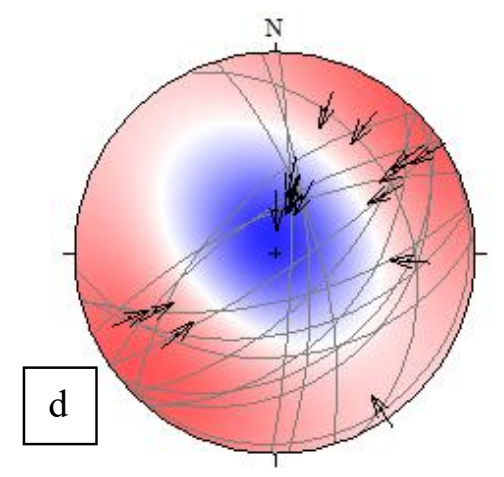

Figure 22 - E-W-oriented compressional field. In: a) T-04; b) T-02; c) T-03; d)T-17. Blue is the extensional field while red is the compressional field.

\subsection{Isopach maps of Santos Basin}

Although there are some research that have connected faults offshore and onshore, structural maps displaying transverse faults in the passive margin basins of southeastern Brazil are unavailable in the literature, as a result of conditions of use and confidentiality by oil companies. For this reason, in order to relate the tectonic events in the Taubaté Basin with the Santos Basin were selected isopach maps of Santos Basin, published in the superb paper by Assine et al.(2008), relative to the interval from Upper Campanian-Maastrichtian, with the uplift of the region of Serra do Mar and Serra da Mantiqueira ranges, until Upper MioceneRecent. The depocenter migration may be related to formation of structures induced by tectonic forces that may acted in continental and marine areas.

The Upper Campanian to Maastrichtian time-interval preceded the installation of the Contintental Rift of Southeastern Brazil. In the continent occurred the alkaline magmatism and the uplift of the area that nowadays encompasses to the Serra do Mar and Serra da Mantiqueira. According to Assine et al. (2008), the sedimentary sequence is characterized by progradational coastal system, related to a major availability of sediments from continental area. 


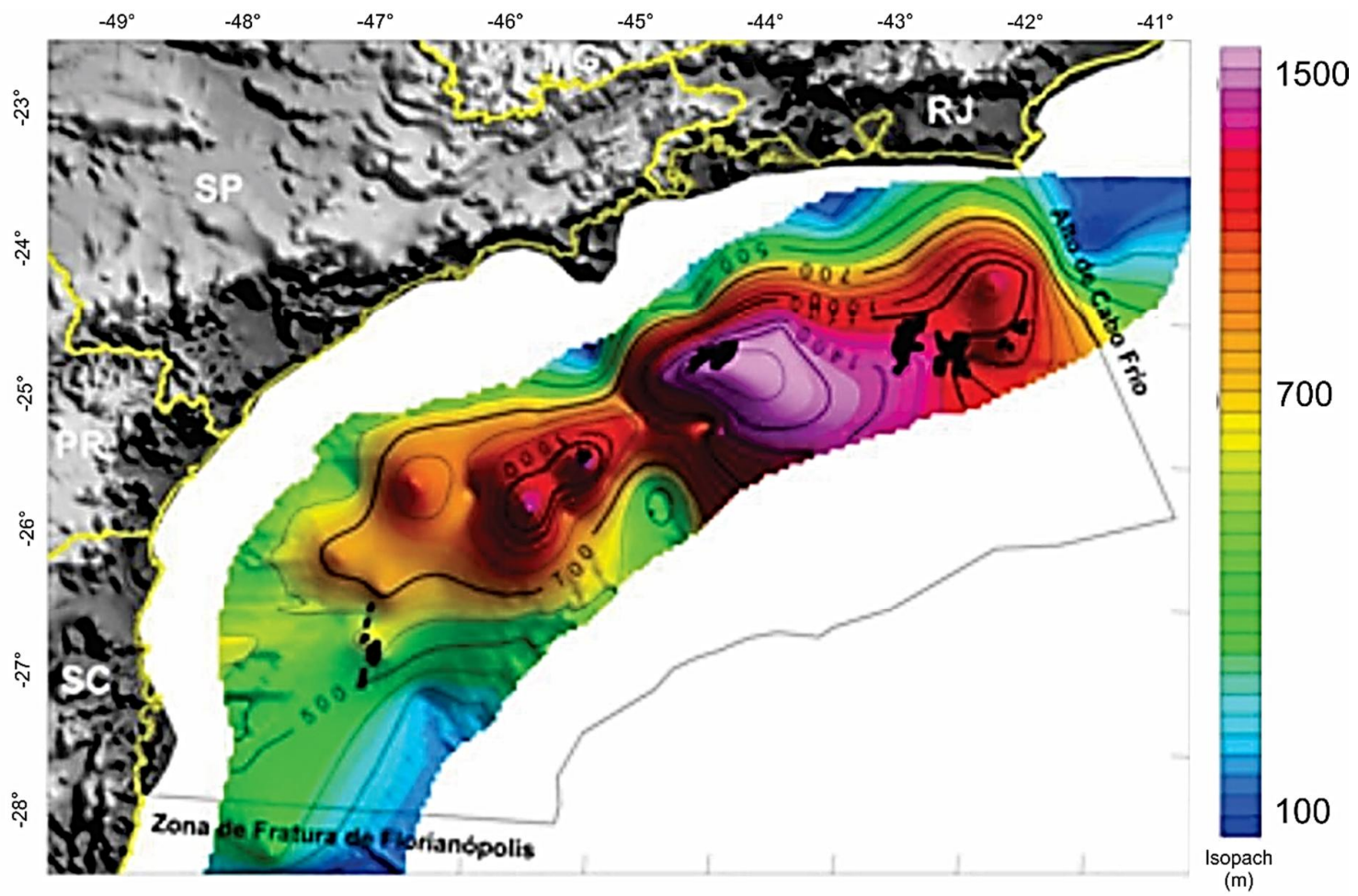

Figure 23 - Isopach maps of Santos Basin during the Upper Campanian - Maastrichtian. In orange: basins of the Central Segment of Continental Rift of Southeastern Brazil (modified from Assine et al., 2008.

In the Figure 23 it is possible to observe three main depocenters that are separated by two major NW-SE-trending structures. The region of greater accumulation of sediments are mainly in front of the uplifted area of Serra do Mar and Serra da Mantiqueira.

The formation of original depression of the Continental Rift of Southeastern Brazil occurred in the Paleogene, being the oldest basin (São João do Itaboraí Basin) from the Paleocene-Eocene (Riccomini et al., 2004). The isopach map of Figure 24 covers the Paleocene to Eocene/Lower Oligocene time-interval, and comprehends the installation and deposition of the rift section of the CRSB. 


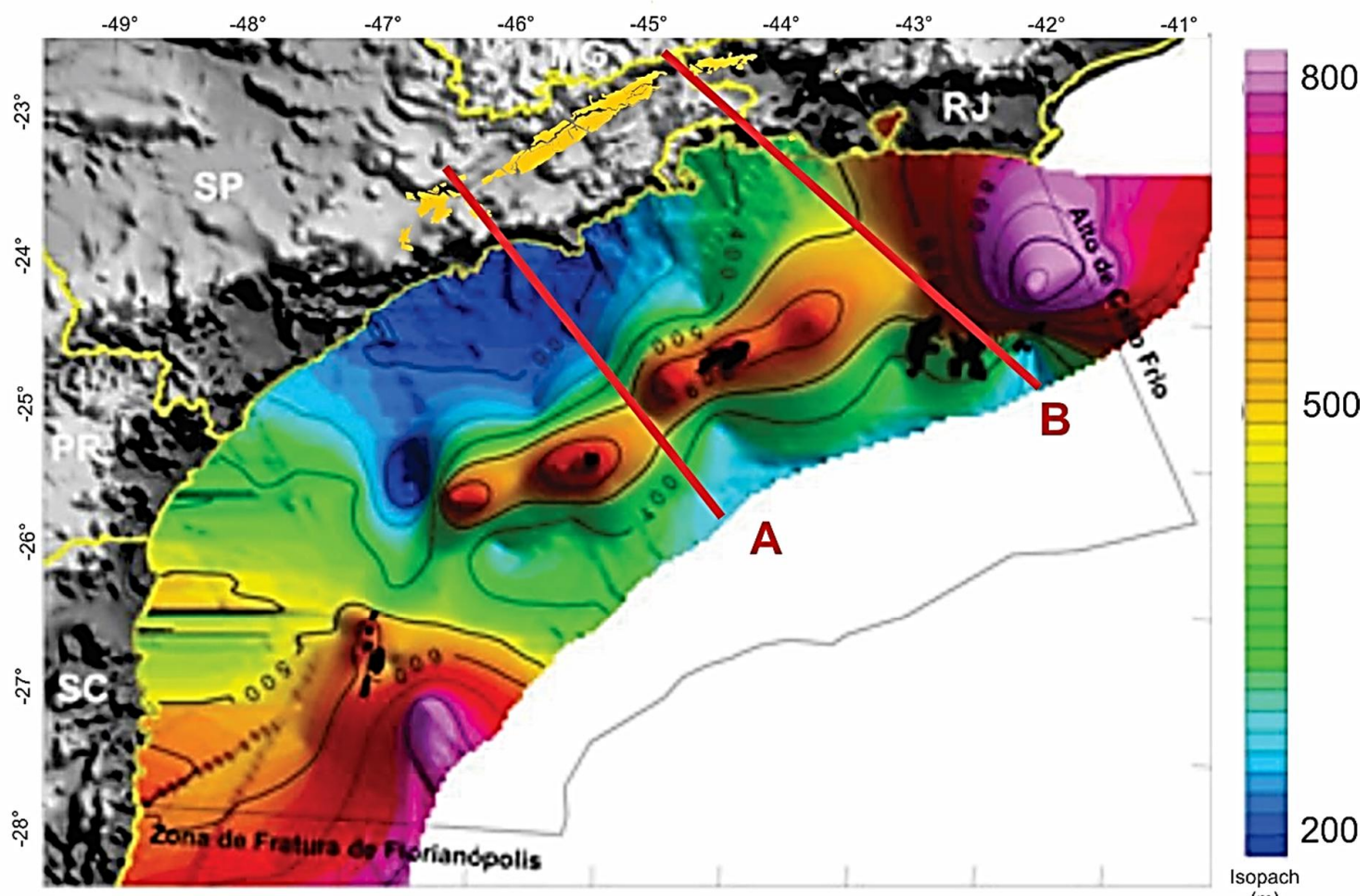

(m)

Figure 24 - Isopach maps of Santos Basin during the Paleocene - Oligocene. In orange: basins of the Central Segment of Continental Rift of Southeastern Brazil; in red: lineaments (modified from Assine et al., 2008).

According to Assine et al. (2008) the limit between Cretaceous and Paleogene is an important unconformity that coincides with a global sea level fall. The depocenters are elongated with strike almost parallel to the coastal line, and roughly parallel to the CRSB. The sedimentary package are thicker near the Cabo Frio High, structure that separate the Santos Basin from Campos Basin. The thinner sedimentary packs occur near the coastline in the São Paulo state. Some authors, as Zalán and Oliveira (2005), defined that the flat surface in the basement in the continental platform of the Santos Basin represents a regional planation surface, named as Japi Surface of the end of Cretaceous (Almeida, 1964), in its lower limit.

The alignment of depocenters in Santos Basin would be a repercussion of the NW-SEoriented extensional field. Two main structures can be observed with probable link between the Santos Basin and the adjoining continental área: a) the Arujá Structural High, which separates the São Paulo and Taubaté basins and whose prolongation offshore marks the left- 
lateral displacement of ENE-WSW-oriented depocenters in Santos Basin (Figure 24,

lineament A); b) the Queluz Structural High, which separates the Taubaté and Resende basins, causing a right-lateral displacement of depocenters in Santos Basin (Figure 24, lineament B).

Isopach map of Upper Miocene to Lower Miocene time-interval (Figure 25) clearly shows the permanence of the lineament A, related to the Arujá Structural High onshore, which in combination with other NW-SE-oriented transverse structures of the southwestern part of the Taubaté Basin (lineament C, Figure 25). A wide shallow region is observed in the coastal region adjoining the Taubaté Basin. The zone of separation between the Taubaté and Resende basins shows at that time a clear prolongation along a WNW-ESE-oriented shallow region (lineament D, Figure 25).
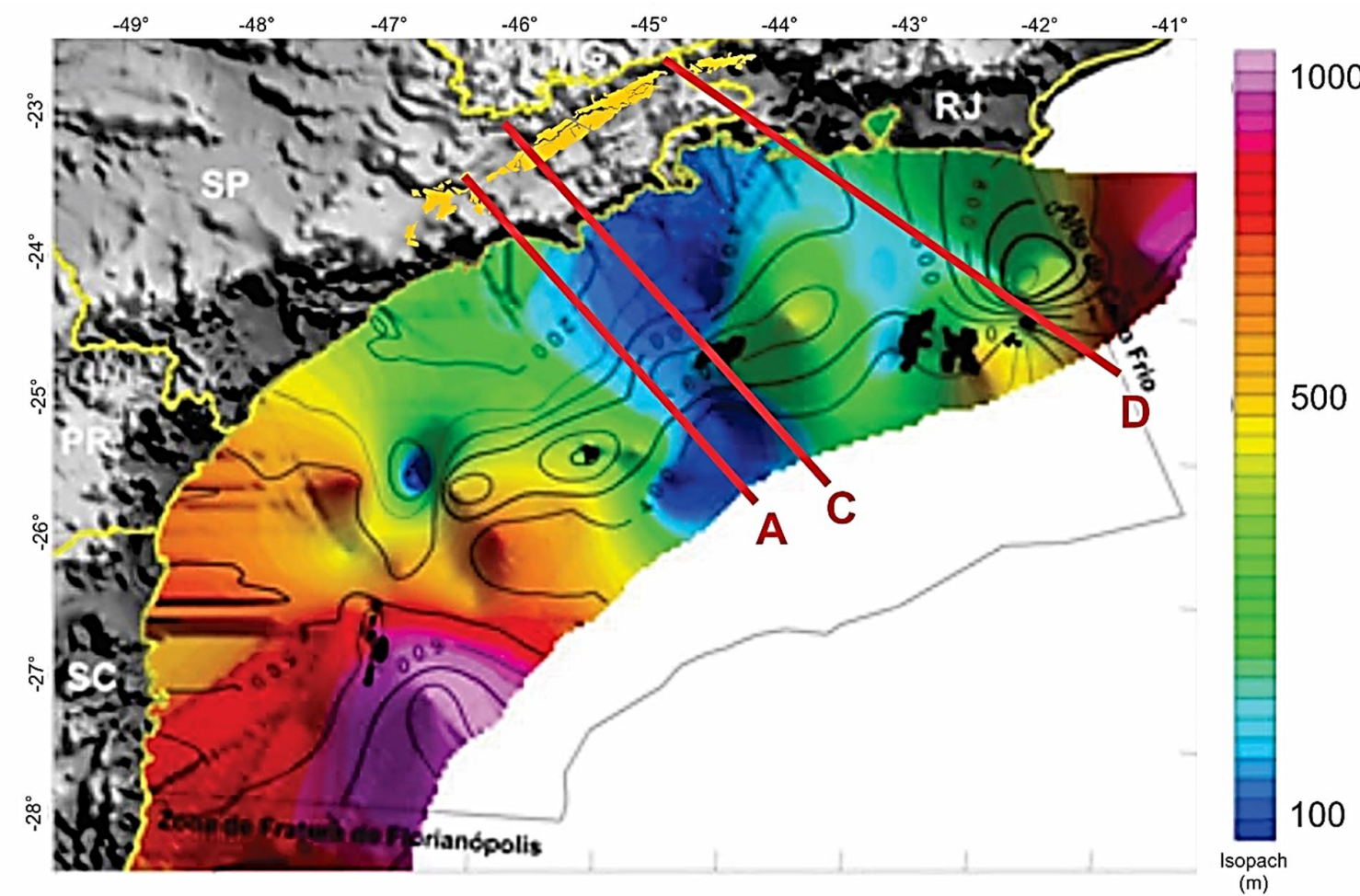

Figure 25 - Isopach maps from Santos Basin during the Upper Oligocene to Lower Miocene. In orange: basins from Central Segment of Continental Rift of Southeastern Brazil; in red: lineaments (modified from Assine et al. 2008) 
The isopach map of Figure 26 corresponds to the time-interval between the Miocene and the Recent. This time-interval encompasses three deformational events in the Taubaté and Resende basins. The influence of lineament A, as well as the shallow coastal region in front of Taubaté Basin remained. NW-SE-oriented structures, as those observed in Taubaté Basin seem to have influenced the depocenter control in the adjoining region in the Santos Basin.
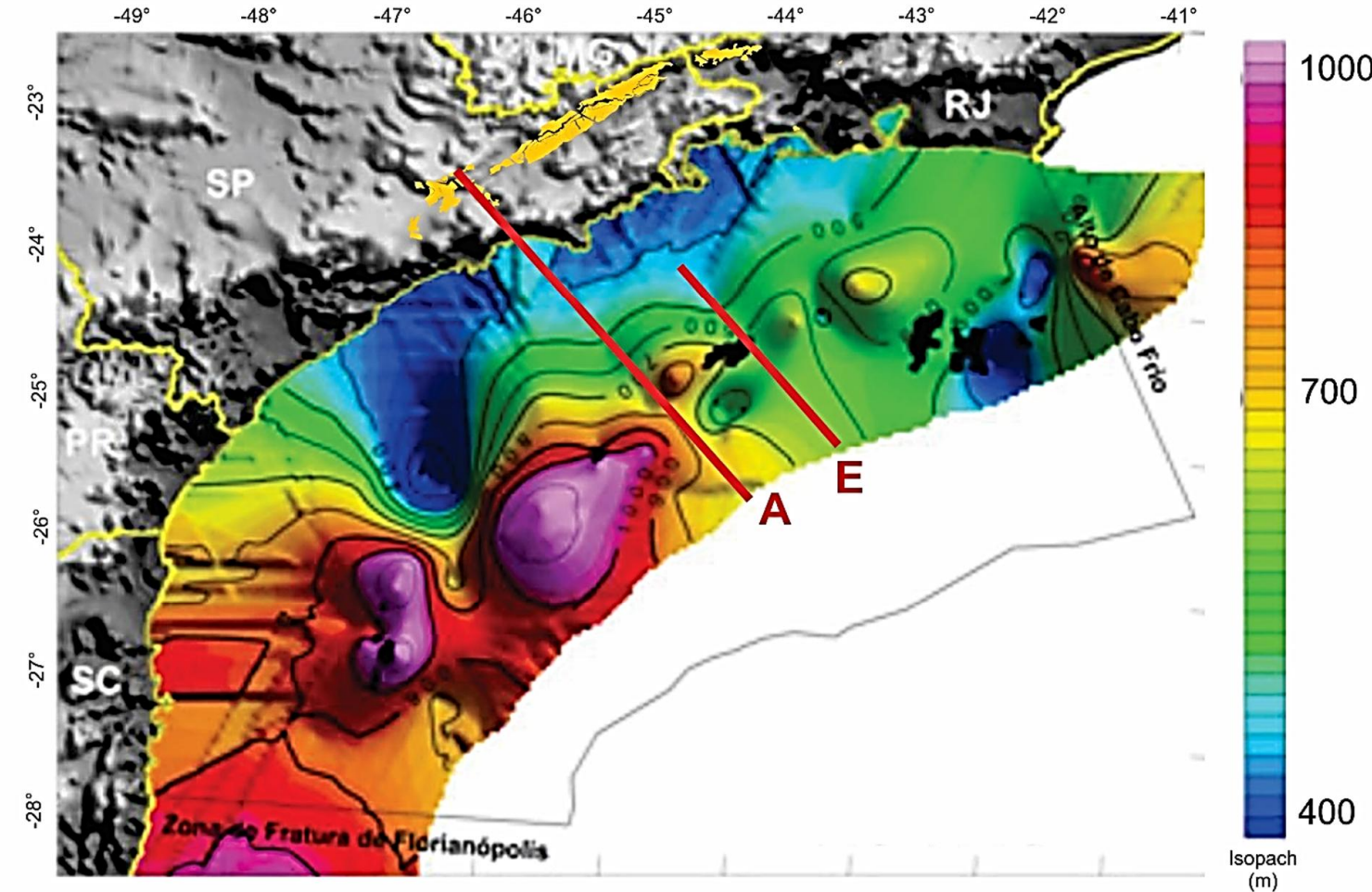

Figure 26 - Isopach maps of Santos Basin during the Miocene to Recent. In orange: basins of the Central Segment of Continental Rift of Southeastern Brazil; in red: lineaments (modified from Assine et al., 2008) 


\section{DISCUSSION}

\subsection{Seismic interpretation}

The seismic profile 225-0061 (Figure 6) crosses the Eugênio de Melo Sub-basin (Marques 1990), with the Caçapava Structural High to the west where Precambrian basement rocks crops out. According to Riccomini (1989) this high is strongly conditioned by NNEoriented faults generated and reactivated during the NW-SE-oriented compressive deformation event that occurred during the Late Pleistocene to Holocene. Using gravimetric data, Fernandes and Chang (2002) modeled the Caçapava High as a non-exposed alkaline body, which might be interfering in deformational processes that originated the basins of the CRSB. This alkaline body could be acted as a discontinuity that allowed its permanence as a high during the rift opening.

Some authors have considered an onlap contact between the basement and the Unit B and the Resende Formation, concluding that the highs are active during the sedimentation (Marques, 1990; Cogné et al., 2013), especially in the Caçapava High. Nonetheless, the onlap contact on the west side of the profile is dubious. There is a possibility that the high was formed during a deformational event, corroborated by the edge faults and the deformation of the sedimentary pack that become progressively steep as it nears to the structural high. Thus, the contact between the sedimentary pile and the basement may demonstrate that not all highs were formed by deformation events, and some of them were active during the sedimentation.

This seismic profile shows that the basement presents reverse and normal faults, but the structure like folds in the basement were considered an artifact related to multiple reflections as the basement is composed of Neoproterozoic crystalline rocks (granitoids, gneisses, and migmatites). These rocks are expected to be in ductile state to fold, which is not this case. Moreover, folds in crystalline rocks have a difficult interpretation on seismic profiles due the 
inability of the current techniques to account for lateral variations in velocity and to display steeply dipping reflectors (Ji and Long, 2006).

The seismic profile 225-0064 (Figure 8) crosses the Capela do Socorro (Marques, 1990) or Pindamonhangaba Structural High (Fernandes, 1993), separating the Quiririm and Roseira depocenters. The sedimentary rocks are mainly deformed over the structural high, but the contacts between them appear to remain near horizontal, which may indicate that the sediment was already deposited when the high was active. The transverse folds in Tremembé Formation described by Riccomini (1989), Takiya et al. (1990) and Silva (2007) are located in the area near this high. The deformation created by the reactivation of this high may have produced folding in shale of the Tremembé Formation during the NE-SW-oriented compressional event of a probable Miocene age (Riccomini et al., 2004).

The seismic profiles 225-0065 and 225-0063 (Figures 9 and 10) crosses the Roseira depocenter, the only sub-basin with Unit A, the oldest in the Taubaté Basin. The presence of a seismic unit exclusively in the Roseira Sub-basin as well as the contact relationship between the sedimentary pack and the basement in some structural highs might demonstrate that the initial rift opening would had occurred in segments, as in the conceptual models presented by Gawthorpe and Leeder (2000). The process of fault propagation, growth and death mainly controls the basin architecture. Thus, basin linkage by burial or breaching of the relays and crossover basement ridges is the dominant mechanism whereby hydrologically closed rifts evolve into open ones (Gawthorpe and Leeder, 2000).

According to Riccomini et al. (2004) there are two anticlines in the area, one is the Caçapava Structural High, trending NE-SW and the other is the Pindamonhangaba Structural High trending NW-SE. The conceptual model described by Gawthorpe and Leeder (2000) 
foresee the presence of transverse anticlines in the hangingwall of normal faults, associated with minimum displacement at segment boundaries.

Furthermore, the presence of a pre-existing structural fabric influences the structural development of the rift system. In extensional settings influenced by a pre-existent structural fabric the mode of fault growth may differ from established fault grown models (Whipp et al., 2014).

The Taubaté Basin had inherited a previously basement discontinuity from the Ribeira Belt and related shear zones. This fact may have propitiated a quick opening of the rift, considering that only Unit A is missing from other seismic profiles. In consequence, it is not necessary to claim a transcurrence to explain the RCSB opening. The existence of active structural highs and exclusive sedimentary packs in one sub-basin would be related to border fault grown, in an extensional regime. The Figure 27 illustrate conceptual model of Gawthorpe and Leeder (2000).
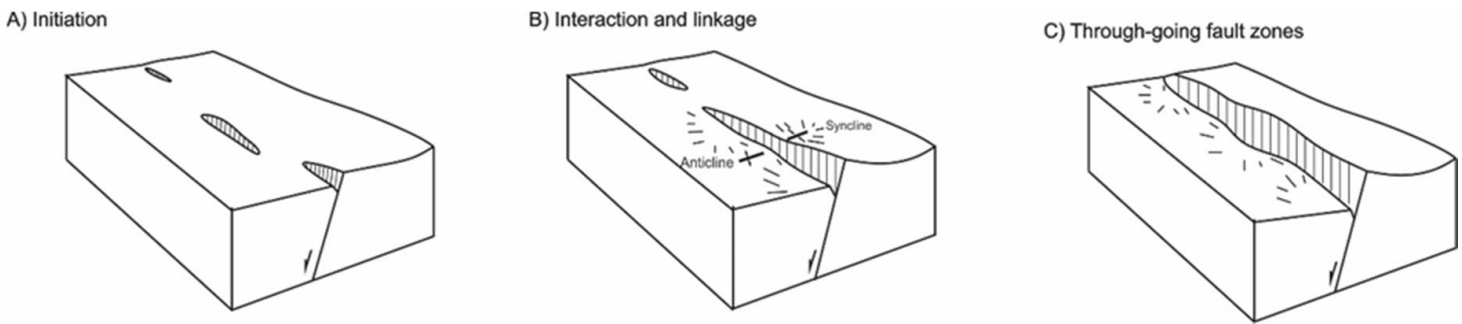

Figure 27 - Schematic 3D evolution of a normal fault array (adapted from Gawthorpe \& Leeder, 2000).

Considering this model for Taubaté Basin it is possible to explain the existence of only one sub-basin nestling the seismic Unit A. Consequently, this segment was the first to form and was delimited by the Pindamonhangaba High, as an anticline. Afterwards the other segments were formed and linked, maintaining the structural highs active, as the Caçapava High. 
5.2 Structural analysis

The Continental Rift of Southeastern Brasil has a polyphasic tectonic evolution. After an initial extensional phase with NNW-SSE-oriented extension, four deformational phases involving reactivations along previous faults and subordinately the formation of new ones are recognized (Riccomini, 1989; Riccomini et al., 2004): a) a strike-slip regime, with NW-SEoriented extension and local NE-SW-oriented compression, active during the Neogene (Miocene); b) a NW-SE-oriented Late Pleistocene to Holocene compressive stress regime followed; c) an E-W- to NW-SE-oriented Holocene extension; d) and an E-W-oriented compression. There are transverse structures in Taubaté and Resende basins related to the generation and deformation of the CRSB.

Transverse structures related to the NW-SE-oriented extension (Eocene - Oligocene) are represented by syn-sedimentary normal faults (sites T-12 and T-13). Paleostress analysis of these faults indicates a general extensional field trending NE-SW, with a vertical compressional field. The direction of extension is at low angle with the direction of the master fault in both sites, located in the northern border of the basins. This result is apparently incompatible with the initial stress field related to the rift opening, identified as an extensional field trending NW-SE (v.g. Riccomini et al., 2004). The studied section in the Resende Basin corresponds to the upper part of the Taubaté Group suggesting that this extension has occurred in a final stage of rift phase.

Based on stress ellipsoids and their relationship with the formation of structures, in an extensional regime it is expected that normal faults would be created perpendicularly to $\sigma 3$ (direction of maximum extension). Nonetheless, according to Gibbs $(1984,1990)$ graben usually shows fault trends at a high angle to the margins, as transverse faults, and in some cases these have been interpreted as later faults. These faults are related to the normal faults 
formation and where called as transfer faults. They allow the escape of tension between extension faults with different slip rates. The main characteristic of these faults is the strikeslip movement and the connection with two distinct normal faults.

Destro (1995) and Destro et al. (2003), based on outcrop and seismic data in the Sergipe-Alagoas Basin, suggested a new type of cross-fault, denominated release fault. Release faults are geometrically required to accommodate variable displacement along the strike of a normal fault as a result of the increase in length of the hangingwall by bending or flexure in the strike direction. They are a type of cross faults and do not cut normal fault planes nor detachment surfaces at depth. Other important characteristic is the type of movement that seems normal without implying in extension along the strike of the basin. Regarding the deformation, release faulting is associated with plane strain deformation in linked extensional fault system (Destro, 1995). Therefore, it is possible to relate transverse faults to an extensional regime, and these faults might be transfer or release faults.

Moreover, according to Destro et al. (2003) the release-faulting model predicts that local paleostress field can strongly diverge from regional one. The stress ellipsoid in the footwall of the normal fault reproduces the regional stresses, where the maximum principal stress $(\sigma 1)$ is vertical, and the minimum principal stress $(\sigma 3)$ is parallel to the extension direction. In release faults, which behave as normal faults, and in release fractures the intermediate principal stress $(\sigma 2)$ and the minimum principal stress $(\sigma 3)$ switch positions and the maximum principal stress $(\sigma 1)$ remains vertical (Figure 28). 


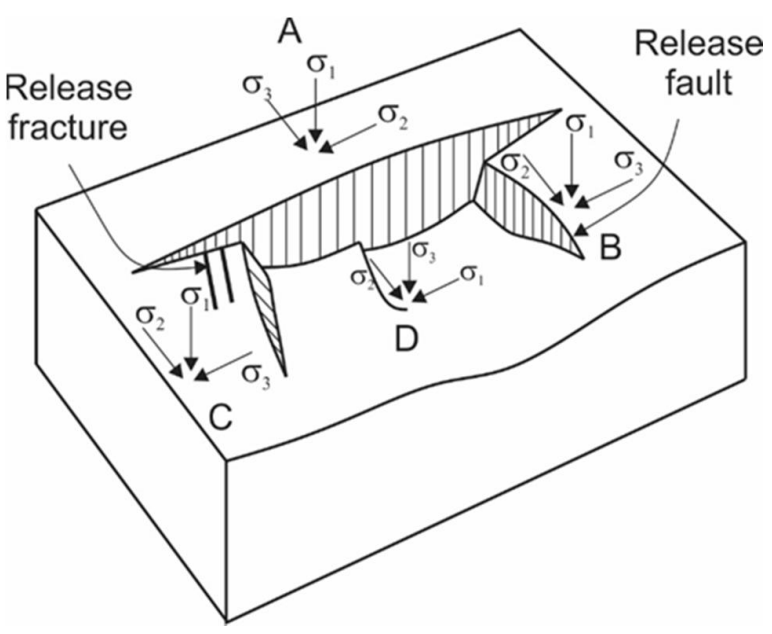

Figure 28 - Conceptual model of stress field in normal and release faults. A) Regional paleostress field; B) Role swap between $\sigma 2$ and $\sigma 3$, causing the formation of release faults. C) Perpendicularly to $\sigma 3$, release fractures may develop parallel to release faults. D) Reversion among the three principal stresses, forming a reverse fault (adapted from Destro et al., 2003)

In the conceptual model of release faults formation is admitted the development of reverse faults locally. Where the downslip is great, compression might occur in the hanging wall, swapping $\sigma 1$ by $\sigma 3$. In this case, $\sigma 3$ becomes vertical and $\sigma 1$ parallel to the strike of parent fault (Destro et al., 2003).

Syn-sedimentary normal faults at the northern borders of the Resende and Taubaté basins are related to master faults and apparently do not intercept nor connect different normal faults. Furthermore, they tend to be oblique to nearly perpendicular to the strike of main faults. The swapping between $\sigma 2$ and $\sigma 3$, considering the regional stress field, is also an important indication that the normal faults described in sites T-12 and T-13 might be considered as release faults, and they are compatible with the regional paleostress field.

Transverse structures related to NE-SW-oriented compression and NW-SE-oriented extension (Miocene) comprise faults and folds. Faults are in part syn-sedimentary in relation to the Itaquaquecetuba Formation. Non-cylindrical, NW-SE-oriented folds in lacustrine shale of Tremembé Formation in the central part of the Taubaté basin are recognized in outcrop (Riccomini, 1989) and regional map scale (Takiya et al., 1990; Silva, 2007). According to 
Silva (2007), these folds present en echelon pattern, both in outcrop and map scale. Fluvial deposits of Pindamonhangaba Formation overlying lacustrine shales are unfolded and separated by an unconformity (Riccomini, 1989). Gawthorpe and Leeder (2000) and Destro et al. (2003) proposed models that predict transverse syn-rift structures formed by a local compression, as folds and reverse faults, respectively. Schlische (1995) pointed that synfolding sedimentary deposits, formed in an extensional setting, are thicker in the hinges of synclines and thinner in the hinge of anticlines. In the Taubaté case, thickness of Tremembé Formation is nearly uniform and folding presents an en echelon array, which is typical of a strike-slip deformation (v.g. Harding 1985). Considering the timing of deformation, postTremembé and pre-Pindamonhangaba Formation, and the direction of fold axes, they are related to the deformational event with NE-SW-oriented compression, of Miocene age.

Deformation related to this event was responsible for generation of transverse structural highs in the basins. Deposition of the Itaquaquecetuba Formation next to the Arujá Structural High was related to this event. The capture of the headwaters of Tietê River by the Paraíba do Sul River also occurred during this event and changed the sedimentary supply from Santos to Campos Basin (Riccomini et al., 2010).

The NW-SE-oriented compression and NE-SW-oriented extension (Late Pleistocene Holocene) has generated mainly normal transverse faults with a general NW-SE-orientation that affects stone-line and colluvium. Given the subvertical dip of some faults and the superposition of striae verified in some cases is likely that they represent reactivations of older strike-slip, transverse faults of the first deformational event, which in turn may indicate the presence of syn-rift, NW-SE-oriented transfer faults in this region of the Taubate Basin.

Transverse faults associated with the E-W- to NW-SE-oriented extension (Holocene) have widespread occurrence both in Resende and Taubaté basins. These faults have a general 
N-S to NNE-WSW-direction and truncate Pindamonhangaba Formation and overlying stoneline and a sandy colluvium. The presence of negative flower structures in the termination of some subvertical normal faults indicate a probable previous strike-slip movement. These data are in agreement with Mancini (1995) who pointed the predominance of normal faults, trending NNW and NNE in this region. Yet, they indicate a clear dominance of an extensional regime during the Holocene in the region of the Caçapava Structural High.

Transverse faults related to the E-W-oriented compression (current stress-field) are scarcely represented in the study area. The most common structural feature related to this stress-regime is a widespread set of neotectonic conjugate hybrid and shear joints in colluvial and alluvial deposits, mainly in the eastern part of the Taubate and western part of the Resende basins (Salvador, 1994; Salvador and Riccomini, 1995), which corresponds to neotectonic joints in the sense of Hancock and Engelder (1989). In the studied cases the variable direction and nature of faults indicate that they were generated during previous deformational events and reactivated under the E-W-compressional stress-field. This is the reason for the high dispersion in the position of striae related to this last deformational event, as the faults were reactivated probably in a non-ideal surface

This E-W-oriented compressional stress field is compatible with the present-day stressfield (Assumpção, 1992, 1998). The southeastern Brazil is located intraplate, and this type of tectonism is related to several mechanisms. According to Assumpção (1992), this compression results from a combination of regional stress (which is related to plate boundary forces and spreading effects due to continent/oceanic crust transition), local flexural effects from thick sedimentary loads (in the passive margin basins as Santos and Campos Basin) and a weaker crust from Mesozoic thinning.

\subsection{Isopach maps}


The Santos Basin constitutes one of the largest marginal depression in the passive margin of Brazil (Macedo, 1989). Its adjacent continental area is formed by crustal blocks of the Ribeira Belt that were tectonically active during the evolution of the basin. The west limit of the Santos Basin comprehends the belt of coastal ranges as Serra do Mar and Serra da Mantiqueira, where the basins from the Continental Rift of Southeastern Brazil were installed.

The continental area adjacent to the Santos, Campos and Espírito Santo basins is characterized by a high topography, with elevations reaching up to $2000 \mathrm{~m}$ (Mohriak et al., 2008). The origin of this mountain range has been considered as related to the retreat of the uplifted margin from Cretaceous until present (Gallagher et al. 1994; Almeida and Carneiro, 1998), secondary flexural bulge generated during rifting that persisted to the present day (Sacek et al., 2012), or rejuvenation of the topography by Late Cretaceous and Cenozoic uplift (Hiruma et al., 2010; Cogné et al., 2011, 2012; Franco-Magalhães et al., 2014). Following continental break-up the continental margin did not behave as a typical passive margin, and a series of Paleogene basins were installed near the continental margin, along the Serra do Mar and Serra da Mantiqueira.

Throughout the geological evolution of Santos Basin, the basin fill was altered by the tectonic events to which the continent and continental margins were subjected. During the Upper Cretaceous, strong sedimentary pulses in the Santos Basin were correlated to expressive uplifts in the continental area, being associated with plutonic alkaline magmatism as registered in the Itatiaia Massif. Later, during the Neogene, the sedimentation of the Santos Basin became fine-grained and with a minor significance caused by the headwater capture of Tietê River, thus the coarse sediments were transported by the Paraíba do Sul River that debouch in the area of the Campos Basin (Macedo, 1989). 
Therefore it is possible to connect the Cenozoic tectonics and sedimentation of the Santos Basin with the formation and evolution of Taubaté and Resende basins.

Asmus and Ferrari (1978), Kumar and Gamboa (1979) and Macedo (1989) proposed that some offshore transfer faults would have a continuity towards the continent, as the Transfer Zones of Florianópolis and Curitiba. According to Macedo (1989) these transfer zones have an important role in the oil industry, with the major occurrences of oil in the Santos Basin located nearby the transfer zones. Souza et al. (2009), using STRM digital elevation models, identified transverse or sub-transverse structures to the coast, with NW-SE direction, in the Precambrian basement of coastal area of southeastern Brazil. Based on seismic profiles, these structures were related to faults and to the evolution and deformation of the north portion of the Santos Basin.

This linkage between onshore and offshore faults was also pointed in Campos Basin (Lourenço et al. 2014) based on interpretation of high-resolution airborne magnetic data. These faults have the same NW-SE-direction indicated by Souza et al. (2009) in the Santos Basin. The faults mapped in the Campos Basin were related to structures in the Barra de São João Graben, a basin of the Continental Rift of Southeastern Brazil located in the Rio de Janeiro state (Lourenço et al. 2014).

Based on the interpretation of the transverse structures in seismic profiles, Souza et al. (2009) recognized four deformational events that affected the Santos Basin. The last two events are related to the formation and deformation of the basins of the Continental Rift of Southeastern Brazil. During the Paleocene, in seismic profiles, were identified normal, reverse and transfer faults sectioning the Eocene section in the Santos Basin. The last phase is associated with neotectonic events, with faults intercepting the Miocene section. The transfer 
faults were correlated by Souza et al. (2009) with transverse structures in the São Paulo, Taubaté, Resende basins as well as with structural highs inside and separating these basins.

During the rift opening, the CRSB was under a NW-SE- to NNW-SSE-oriented extension, generating normal faults trending E-W to ENE-WNW. As explained previously there are two types of transverse faults that are related to extensional regime: transfer faults (Gibbs 1984, 1990) and release faults (Destro, 1998 and Destro et al. 2003). The main difference between transfer and release faults are the movement (strike-slip or normal dipslip) and the linkage between normal fault planes (only transfer faults connect two or more faults). Among the structural data, there were one fault set related to release faults, but the sedimentary register of transverse faults associated to the initial extensional stress-field is scarce.

The alignment of depocenters in Santos Basin would be a repercussion of the NW-SEoriented extensional field. Two transverse structures have a probable link between the Santos Basin and the central segment of the CRSB, the lineaments A (the continuity of the Arujá Structural High) and B (the prolongation of the Queluz Structural High) (Figure 24). These structures are probable transfer zones in the Santos Basin, as they imposed a seesaw movement in the basin, with depocenter between A and B lineaments displacing northwestwards in relation to depocenters to the SW and NW.

In the Lower Miocene the left-lateral transcurrence, with a compression trending NWSE, promoted an important change in the Taubaté Basin. The previous pattern was altered by the formation of structural highs that segmented the rift. One of these highs changed the drainage, with the capture of the Tietê River headwater by the Paraíba do Sul River. Moreover, the blocks in the Taubaté Basin tilted as a seesaw. 
As shown in the isopach map of Upper Miocene to Lower Miocene time-interval (Figure 25), lineaments A and C (Figure 25) seem to configure a major transfer zone limiting shallow areas of the basement in the Santos Basin to NW and SE, respectively to the N and S of this zone. The shallow region along the coastal region adjoining the Taubaté Basin may suggest that, together with this segment of the Serra do Mar, the entire region experienced uplift. The continuity of a WNW-ESE-oriented fault zone offshore (lineament D, Figure 25) probably represents a relay ramp zone in Santos Basin. This zone is probably exposed onshore along the WNW-ESE-oriented Funil Fault Zone (Riccomini, 1989) and the faults in the Itatiaia alkaline Massif, of the same orientation (Figure, 15).

According to Assine et al. (2008), after the Miocene the region was marked by eustatic fluctuations related to global cycles of glaciation. The time-interval between the Late Pleistocene and the Recent comprises three deformational events in the central segment of the CRSB. The isopach map of Miocene to Recent (Figure 26) evince that Lineament A was still active at that time and probably some transverse structures played some role on the control of depocenters in the Santos Basin.

It seems clear that only the NW-SE-oriented structures exerted influence in the Santos Basin during its Cenozoic evolution. These structures were active predominantly as transfer faults that have divided the basin in compartments. In particular, lineament A, which corresponds to the extent offshore of the Arujá Structural High, seems to have had a longlived, multiphase activity during the Cenozoic. Major oil fields in the Santos Basin are localized in the region adjoining the Taubate and Resende basins, roughly between NW-SEoriented lineaments A and B. This fact would suggest that these structures together other NWSE-oriented faults and folds may have influenced, respectively, the migration routes and structural traps in the Santos Basin. 


\section{CONCLUSIONS}

The main focus of this paper was the study of the transverse structures in the Taubate and Resende basins focusing on their nature, geometry, kinematics, relationships with sedimentation, age, the stress field active during their generation and deformation, and regional correlations. Besides, the possible physical continuity of these structures and/or the action of stress fields related to them into the Santos Basin and the implications for the tectonic framework and evolution of this basin were also analyzed. The key conclusion of this study are as follow:

a) transverse faults in longitudinal seismic profiles are usually steep, with normal, reverse and strike-slip character; all the seismic units are deformed by faults, including the younger sedimentary packs, but all faults were identified as pre and post-sedimentary;

b) structural highs were identified in seismic profiles, some of them active during the installation of the Taubaté Basin;

c) the existence of active structural highs and exclusive sedimentary packs in one sub-basin would be related to border fault grown, in an extensional regime

d) fault-slip data inversion and paleostress determination allowed to identify that there are transverse structures related to the five tectonic events previously reported to the central segment of the CRSB;

e) transverse structures related to the initial NW-SE-oriented extensional event (Eocene Oligocene) are represented by syn-sedimentary normal faults related to master faults and apparently not intercepting nor connecting different normal faults; these faults indicate a general extensional field trending NE-SW, which allowed to classify them as release faults; 
f) transverse faults associated with the NE-SW-oriented compression and NW-SE-oriented extension (Miocene) are in part syn-sedimentary in relation to the Itaquaquecetuba Formation; the nearly uniform thickness of folded layers of Tremembé Formation associated with their en echelon array, indicate that they are related to the deformational event with NE-SW-oriented compression;

g) transverse faults related to the NW-SE-oriented compression and NE-SW-oriented extension (Late Pleistocene - Holocene) are mainly normal, with a general NW-SEorientation, affecting stone-line and colluvium; some of these faults with subvertical dip and showing superposition of striae probably represent reactivations of older strike-slip, transverse faults;

h) the E-W- to NW-SE-oriented extension (Holocene) has generated transverse faults with a general N-S- to NNE-WSW-direction that truncate the Pindamonhangaba Formation and overlying stone-line and a sandy colluvium;

i) a few faults related to the E-W-oriented compression (current stress-field) were recognized in the study area; the variable direction and nature of faults indicate that they were generated during previous deformational events and reactivated, thus showing high dispersion in the position of striae related to this last deformational event as the faults were reactivated along non-ideal previous fault surfaces;

j) only the NW-SE-oriented structures exerted influence in the Santos Basin during its Cenozoic evolution; five lineaments with this direction were recognized in isopach maps, showing a probable continuity offshore and controlling depocenters in the Santos Basin: the lineaments A (the continuity of the Arujá Structural High) and B (the prolongation of the Queluz Structural High), during the Paleocene-Oligocene; lineaments A, C and lineament D, during the Miocene; and lineaments A and E during the Late-Pleistocene to Recent. 
h) these structures were active predominantly as transfer faults, which have divided the basin in compartments; in particular, lineament A, corresponding to the extent offshore of the Arujá Structural High, seems to have had a long-lived, multiphase activity during the Cenozoic; i) major oil fields in the Santos Basin are localized in the region adjoining the Taubate and Resende basins, roughly between NW-SE-oriented lineaments A and B, which would suggest the combined influence of these structures together other NW-SE-oriented faults and folds in the migration routes and formation of structural traps in the Santos Basin.

\section{ACKNOWLEDGMENTS}

We thank the Programa de Recursos Humanos Petrobras PRH-241, Agência Nacional do Petróleo, Gás Natural e Biocombustíveis (ANP, Brazil)), Financiadora de Estudos e Projetos (FINEP, Brazil, grant Ref. 1452/13) and Conselho Nacional de Desenvolvimento Científico e Tecnológico (CNPq, Brazil, grant \#307871/2010-0) for the financial support.

\section{REFERENCES}

Ab'Sáber, A. N., 1962. Revisão dos conhecimentos sobre o horizonte sub-superficial de cascalhos inhumados do Brasil Oriental. Universidade Federal do Paraná, Boletim Geografia Física 2, $32 \mathrm{p}$.

Almeida, F.F.M., 1964. Fundamentos geológicos do relevo paulista. Boletim do Instituto Geográfico e Geológico 41, 167-263.

Almeida F.F.M., 1976. The system of continental rifts bordering the Santos Basin, Brazil. Anais da Academia Brasileira de Ciências 48 (suplemento), 15-26. 
Almeida F.F.M., Carneiro C.D.R. 1998. Origem e evolução da Serra do Mar. Revista Brasileira de Geociências 28, 135-150.

Alves A., Janasi V.A., Campos Neto M.C., Heaman L., Simonetti A., 2013. U-Pb geochronology of the granite magmatism in the Embu Terrane: Implications for the evolution of the Central Ribeira Belt, SE Brazil. Precambrian Research 230, 1-12.

Angelier J., Mechler P., 1977. Sur une méthode graphique de recherche des contraintes principalel égalament utilisable em tectonique et em séismologie: la méthode des dièdres droits. Bulletin Société Géologique de France 19, 1309-1318

Angelier J., 1994. Fault slip analysis and paleostress reconstruction. In: Hancock P.L. (eds). Continental Deformation. Oxford, Pergamon, p. 53-120.

Asmus H.E., Ferrari A.L., 1978. Hipótese sobre a causa do tectonismo cenozoico na região sudeste do Brasil. Projeto REMAC 4, 75-88.

Assine M.L., Corrêa F.S., Chang H.K., 2008. Migração de depocentros na Bacia de Santos: importância na exploração de hidrocarbonetos. Revista Brasileira de Geociências 38(Suplemento), 111-127.

Assumpção M., 1992. The regional intraplate stress field in South America. Journal of Geophysical Research 97 (B8), 889-903.

Assumpção M., 1998. Seismicity and stresses in Brazilian Passive Margin. Bulletin of the Seismological Society of America 88, 160-169. 
Campanha G. A.C., 2002. O papel do sistema de zonas de cisalhamentos transcorrentes na configuração da porção meridional da Faixa Ribeira. Tese de livre-docência. Instituto de Geociências, Universidade de São Paulo, 105 p.

Caputo, R., 1995. Evolution of orthogonal sets of coeval extension joints. Terra Nova 7,479490.

Cassini, L.V., 2011. Tectônica neocretácea-paleógena da área da Bacia de Volta Redonda, $R J$. Monografia de trabalho de formatura. Instituto de Geociências, Universidade de São Paulo, 24 p.

Chang H.K., Kowsmann R.O., 1984. Subsidência térmica e espessura crustal na Bacia de Santos. In: $33^{\circ}$ Congresso Brasileiro de Geologia, Anais, v.2, p. 1602-1614.

Chang H.K., Assine M.L., Corrêa F.S., Tinen J.S., Vidal A.C., Koike L., 2008. Sistemas petrolíferos e modelos de acumulação de hidrocarbonetos na Bacia de Santos. Revista Brasileira de Geociências 38 (2 - suplemento), 29-46.

Christie-Blick N., Biddle K.T., 1985. Deformation and basin formation along strike-slip faults. In: Biddle K.T \& Christie-Blick N. (eds). Strike-Slip deformation, basin formation, and sedimentation. Oklahoma, Society of Economic Paleontologists and Mineralogists, p. 1-34.

Cobbold P.R., Meisling K.E., Mount V.S., 2001. Reactivation of an obliquely risted margin, Campos and Santos basins, southeastern Brazil. AAPG Bulletin 85, 1925-1944.

Cogné N., Gallagher K., Cobbold P.R., 2011. Post-rift reactivation of the onshore margin of southeast Brazil: Evidence from apatite (U-Th)/He and fission-track data. Earth and Planetary Science Letters 309, 118-130. 
Cogné N., Gallagher K., Cobbold P. R., Riccomini C., Gautheron C., 2012. Post-breakup tectonics in southeast Brazil from thermochronological data and combined inverse-forward thermal history modeling, Journal of Geophysical Research 117, B11413.

Cogné N., Cobbold P.R., Riccomini C., Gallagher K., 2013. Tectonic setting of the Taubaté Basin (Southeastern Brazil): Insights from regional seismic profiles and outcrop data. Journal of South American Earth Sciences 42,194-204.

Cohen K.M., Finney S.C., Gibbard P.L., Fan J.X., 2013. The ICS International Chronostratigraphic Chart. Episodes 36, 199-204.

Destro, N., 1995. Release fault: A variety of cross fault in linked extensional fault systems, in the Sergipe-Alagoas Basin, NE Brazil. Journal of Structural Geology 17, 615-629.

Destro N., Szatmari P., Alkmin F.F., Magnavita L.P., 2003. Release faults, associated structures, and their control on petroleum trends in the Recôncavo rift, northeast Brazil. AAPG Bulletim 87, 1123-1144.

Fernandes F.L., 1993. Arcabouço estrutural e evolução da Bacia de Taubaté - SP. MS dissertation, Escola de Minas, Universidade Federal de Ouro Preto, Ouro Preto, 147p.

Fernandes F.L \& Chang H.K., 2002. Modelagem gravimétrica da Bacia de Taubaté. Revista Brasileira de Geofisica 19, 131-144.

Ferrari A. L., 2001. Evolução tectônica do Graben da Guanabara. PhD thesis, Instituto de Geociências, Universidade de São Paulo, p. 412. 
Franco-Magalhães A.O.B., Cuglieri M.A.A., Hackspacher P.C., Saad A.R., 2014. Long-term landscape evolution and post-rift reactivation in the southeastern Brazilian passive continental margin: Taubaté basin. International Journal of earth Sciences 103, 441-553.

Gallagher, K., Hawkesworth, C.H., Mantovani, M.S.M., 1994. The denudation history of the onshore continental margin of the SE Brazil inferred from apatite fission track data. Journal of Geophysical Research 99, 18,117-8,145.

Gawthorpe R.L., Leeder M.R., 2000. Tectono-sedimentary evolution of active extensional basins. Basin Research 12, 195-218.

Gibbs A.D., 1984. Structural evolution of extensional basin margins. Gibbs, A.D. 1984. Structural evolution of extensional basin margins. Journal of the Geological Society 141, $609-620$.

Gibbs, A.D., 1990. Linked fault families in basin formation. Journal of Structural Geology $12,795-803$.

Hancock, P.L., Engelder, T., 1989. Neotectonic joints. Geological Society of America Bulletin $101,1197-1208$.

Harding, T.P., 1985. Seismic characteristics and identification of negative flower structures positive flower structures, and positive structural inversion. Bulletin of the American Association of Petroleum Geologists 69, 582-600.

Hasui Y., Carneiro C.D.R., Coimbra A.M., 1975. The Ribeira folded belt. Revista Brasileira de Geociências 5, 257-266.

Hiruma S.T., Riccomini C., Modenesi-Gauttieri M.C., Hackspacher P.C., Hadler Neto J.C., 
Franco-Magalhães A.O.B., 2010. Denudation history of the Bocaina Plateau, Serra do Mar, southeastern Brazil: Relationships to Gondwana breakup and passive margin. Gondwana Research 18, 674-687.

Ji S., Long C., 2006. Seismic reflection response of folded structures and implications for the interpretation of deep seismic reflection profiles. Journal of Structural Geology 28, 13801387.

Kumar N., Gamboa L.A., 1979. Evolution of the São Paulo Plateau (South easthern brazilian margin) and implication for the early history of South Athlantic. Geological Society of America Bulletin 90, 281-293.

Leite C.A.S., Perrota M.M., Silva L.C., Heineck C.A., Salvador E.D., Vieira V.S., Lopes R.C., Silva M.G.M., Drumond J.B.V., Malouf R.F., Lacerda Filho J.V., Valente C.R., Gomes S.D., Sachs L.L.B., Oliveira I.W.B., Ramgrab G.E., Netto C., Junqueira P.A., Paes V.J.C., 2004. Folha SF.23 - Rio de Janeiro. In: Schobbenhaus C., Gonçalves J.H., Santos J.O.S., Abram M.B., Leão Neto R., Matos G.M.M., Vidotti R.M., Ramos M.A.B., Jesus J.D.A. (eds). Carta Geológica do Brasil ao Milionésimo, Sistema de Informações Geográficas. Programa Geologia do Brasil. CPRM, Brasilia.

Lima C., Nascimento E., Assumpção M., 1997. Stress orientation in Brazilian sedimentary basins from breakout analysis: implications for force models in the South American plate. International Journal of Geophysics 130, 112-124.

Lourenço J., Menezes P.T.L., Barbosa V.C.F., 2014. Connecting onshore-offshore Campos Basin structures: Interpretation of high-resolution airborne magnetic data. Interpretation 2, $181-191$. 
Macedo L.M., 1989. Evolução tectônica da Bacia de Santos e áreas continentais adjacentes. Boletim de Geociências da Petrobras 3, 159-173.

Mancini F., 1995. Estratigrafia e aspectos da tectônica deformadora da Formação

Pindamonhangaba, Bacia de Taubaté, SP. MSc dissertation. Instituto de

Geociências, Universidade de São Paulo, 107 p..

Marques A., 1990. Evolução tectono-sedimentar e perspectivas exploratórias da Bacia de Taubaté, São Paulo, Brasil. Boletim de Geociências da Petrobras 4, 221-240.

Meisling K.E., Cobbold P.R., Mount S.V., 2001. Segmentation of an obliquely rifted margin, Campos and Santos Basin, southeastern Brazil. AAPG Bulletin 85, 1903-1924.

Melo M. S., Riccomini C., Hasui Y., Almeida F.F. M., Coimbra, A.M., 1985. Geologia e evolução do sistema de bacias tafrogênicas continentais do sudeste do Brasil. Revista Brasileira de Geociências 15, 193-201.

Mello C.L., Moura J.R.S., Suguio K., 1999. Um evento de intensa sedimentação aluvial durante o Holoceno (inicial a médio) no Sudeste do Brasil e o papel dos condicionantes paleoclimáticos e neotectônicos. In: $7^{\circ}$ Congresso da ABEQUA (avaiable in: www.abequa.org.br)

Mohriak W., Nemčok M., Enciso G., 2008. South Athantic divergente margin evolution: riftborder uplift and salt tectonics in the basin of SE Brazil. Journal of the Geological Society 294 (Special Publications), p. 365-398.

Moulin M., Aslanian D., Unternehr P., 2010. A new starting point for the South and Equatorial Atlantic Ocean. Earth-Science Reviews 98, 1-37. 
Orife T., Lisle R.J., 2006. Assessing the statistical significance of paleostress simulatons using random fault-slips. Journal of Structural Geology, 28, 952-956.

Pereira M.J., Barbosa C.M., Agra J., Gomes J.B., Aranha L.G.F., Saito M., Ramos M.A., Carvalho M.D., Stamato M., Bagni O., 1986. Estratigrafia da Bacia de Santos. Análise das sequências, sistemas deposicionais e revisão litoestratigráfica. In: SBG, $34{ }^{\circ}$ Congresso Brasileiro de Geologia, Anais, v.1, p. 65-79.

Perrota M.M., Salvador E.D., Lopes R.C., D’Agostinho L.Z., Peruffo N., Gomes S.D., Sachs L.L.B., Meira V.T., Garcia M.G.M., Lacerda Filho J.V., 2005. Mapa Geológico do Estado de São Paulo, escala 1:750.000. Programa Geologia do Brasil - PGB, CPRM, São Paulo.

Ramos R.R.C., Mello C.L., Sanson M.S.R., 2006. Revisão estratigráfica da Bacia de Resende, Rift Continental do Sudeste do Brasil, Estado do Rio de Janeiro. Geociências 25, 59-69.

Riccomini C., Melo M.S., Almeida F.F.M., Carneiro C.D.R., Mioto J.A., Hasui Y., 1983. Sobre a ocorrência de um derrame de ankaramito na Bacia de Volta Redonda (RJ) e sua importância na datação das bacias tafrogênicas continentais do sudeste brasileiro. In: $4^{\circ}$ Simpósio Regional de Geologia, Resumos, p. 23-24.

Riccomini C., Appi C.J., Freitas E.L., Arai M., 1987. Tectônica e sedimentação no Sistema de Rifts Continentais da Serra do Mar (Bacias de Volta Redonda, Resende, Taubaté e São Paulo). In: $1^{\circ}$ Simpósio de Geologia RJ-ES, Anais, p. 253-298.

Riccomini C., Peloggia A.U.G., Saloni J.C.L., Kohnke M.W., Figueira R.M., 1989. Neotectonic activity in the Serra do Mar Rift System (Southeastern Brazil). Journal of South American Earth Sciences 2, 191-197. 
Riccomini C., 1989. O Rift Continental do Sudeste do Brasil. PhD thesis, Instituto de Geociências, Universidade de São Paulo, 256 p.

Riccomini C., Coimbra A.M., Suguio K., Mihály P., Maturana E.C., 1991. Nova unidade litoestratigráfica cenozoica da Bacia de Taubaté, SP: Formação Pindamonhangaba. Boletim IG-USP 9 (publicação especial), 141-149.

Riccomini C., Sant'Anna L.G., Ferrari, A.L., 2004. Evolução geológica do rift continental do Sudeste do Brasil. In: Mantesso-Neto V.; Bartorelli A.; Carneiro C.D.R.; Brito -Neves B.B. (eds.) Geologia do continente Sul-Americano: evolução da obra de Fernando Flávio Marques de Almeida. Beca, São Paulo, p. 383-405.

Riccomini C., Veláquez V.F., Gomes C.B., 2005. Tectonic controls of the Mesozoic and Cenozoic alkaline magmatism in central-southeastern Brazilian Platform. In: Gomes C.B. and Comin-Chiaramonti P., orgs., Mesozoic to Cenozoic alkaline magmatism in the Brazilian Platform. São Paulo, EDUSP-FAPESP, p. 31-55.

Riccomini C., Grohmann C.H., Sant’Anna L.G., Hiruma S.T., 2010. A captura das cabeceiras do Rio Tietê pelo Rio Paraíba do Sul. In: Modenesi-Gautieri, M.C., Bartorelli A., MantessoNeto V., Carneiro C.D.R., Lisboa M.B.A.L. (eds.) A obra de Aziz Nacib Ab 'Sáber. Beca,São Paulo, p. 157-169.

Sacek V., Braun J., van der Beek P., 2012. The influence of rifting on escarpment migration on high elevation passive continental margins. Journal of Geophysical Research 117:B04407.

Sadowski, G.R.; Dias Neto, C. de M., 1981. O Lineamento sismo-tectônico de Cabo Frio. Revista Brasileira de Geociências 11, 209-212 
Salvador E.D., 1994. Análise tectônica do Vale do Rio Paraíba do Sul compreendida entre Cruzeiro (SP) e Itatiaia (RJ). MSc Dissertation, Instituto de Geociências, Universidade de São Paulo, 129 p..

Salvador E.D., Riccomini C., 1995. Neotectônica da região do alto estrutural de Queluz (SPRJ, Brasil). Revista Brasileira de Geociências 25, 151-164.

Silva T.B., 2007. Estocagem subterrânea de gás na Bacia de Taubaté. Final course assignment. Instituto de Geociências, Universidade de São Paulo, 41 p..

Silva T P., Mello C.L. 2011. Reativações neotectônicas na Zona de Cisalhamento do Rio Paraíba do Sul (Sudeste do Brasil). Geologia USP - Série Científica 11, 95-111.

Souza I.A., Ebert H.D., Castro J.C., Soares Júnior A.V., Silva G.H.T., Benvenutti C.F., 2009. Caracterização das falhas de transferência na porção norte da Bacia de Santos a partir da integração de dados geológicos e geofísicos. Boletim de Geociências da Petrobras 17, 109132.

Takiya H., Riccomini C., Landim P.M.B., 1990. Estudo tectônico da porção central da Bacia de Taubaté (SP) por geoestatística. Geociências 9, 185-196.

Whipp P.S., Jackson C. A-L., Gawthorpe R.L., Dreyer T., Quinn D., 2014. Normal fault array evolution above a reactivated rift fabric; a subsurface example from the northern Horda Plataform, Norwegian North Sea. Basin Research 24, 523-549.

Zalán P.V., 1986. Identificação de falhas transcorrentes em seções sísmicas. Revista Brasileira de Geociências 16, 258-265. 
Zalán P.V., Oliveira J.A.B. 2005., Origem e evolução estrutural do Sistema de Riftes Cenozóicos do Sudeste do Brasil. Boletim de Geociências da Petrobras 13, 269-300.

Žalohar J., Vrabec M., 2007. Paleostress analysis of heterogeneous fault-slip data: The Gauss method. Journal of Structural Geology 29, 1798-1810. 